\title{
FORAGE CROPS in the Aspen Parklands of Western Canada
}

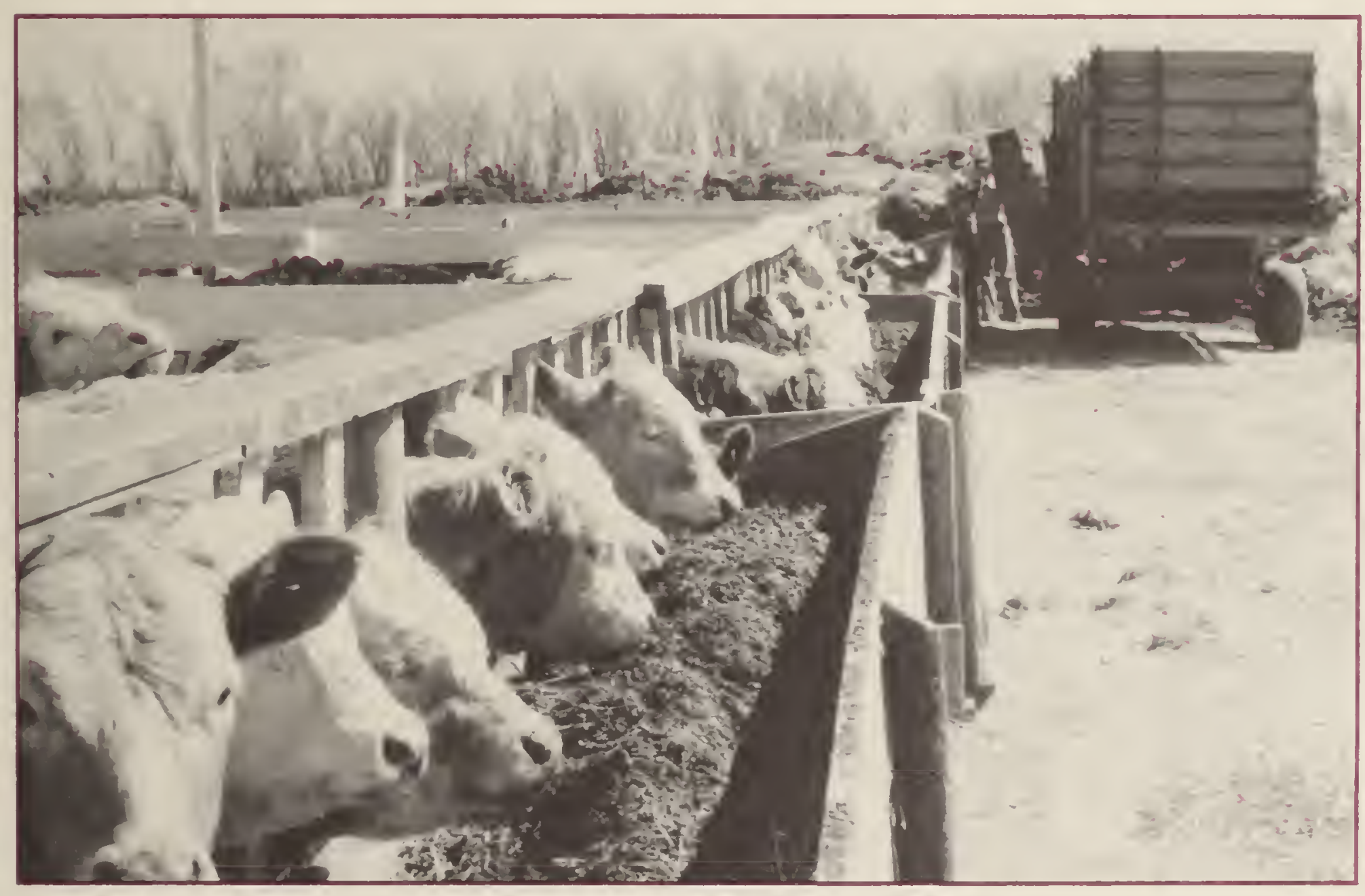

\section{- FEEDING FORAGE CROPS•}

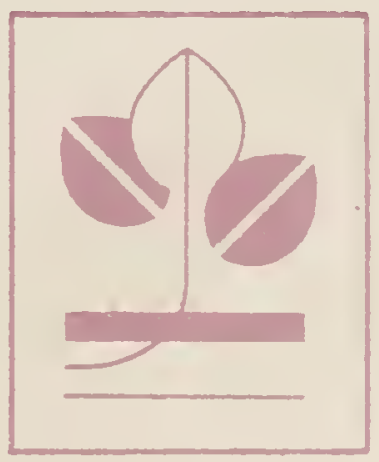


Digitized by the Internet Archive in 2012 with funding from

Agriculture and Agri-Food Canada - Agriculture et Agroalimentaire Canada 


\section{FORAGE CROPS in the Aspen Parklands of Western Canada}

- FEEDING FORAGE CROPS •

ResearchStation Melfort, Saskatchewan

Research Branch

Agriculture Canada

Publication 1874/E

1991 
(C) Minister of Supply and Services Canada 1991

Available in Canada through

Associated Bookstores

and other booksellers

or by mail from

Canada Communications Group-Publishing

Ottawa, Canada KIA 0S9

Cat. No. A53-1874/1991E

ISBN 0-660-14060-8

\section{Canadian Cataloguing in Publication Data}

Beacom, S. E., 1926-

Forage crops in the aspen parklands of Western Canada. Feeding forage crops

(Publication ; 1874/E)

Author: S.E. Beacom. Cf. P. v.

Cat. no. A53-1874/199IE

ISBN $0-660-14060-8$

1. Forage plants-Canada, Western. I. Canada. Agriculture Canada. Research Station (Melfort,

Sask.) II. Title. III. Title: Feeding forage

crops. IV. Series: Publication (Canada.

Agriculture Canada). English; 1874/E.

SB193.3.C3B43 1991 633.2'009712 C9I-099109-XE 


\section{CONTENTS}

FOREWORD $\ldots \ldots \ldots \ldots \ldots \ldots \ldots \ldots \ldots \ldots \ldots \ldots \ldots \ldots \ldots \ldots \ldots \ldots \ldots \ldots \ldots$

ACKNOWLEDGMENTS ................................... v

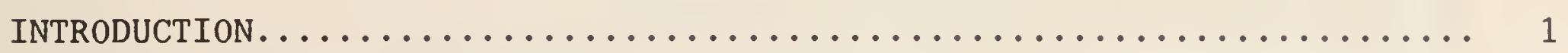

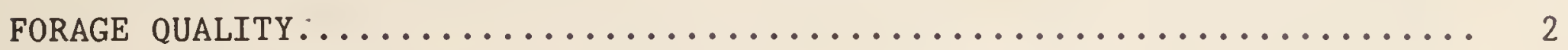

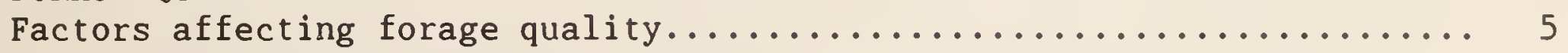

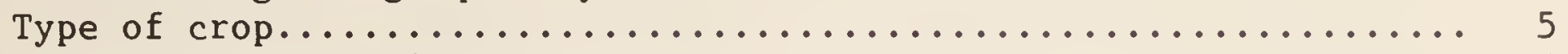

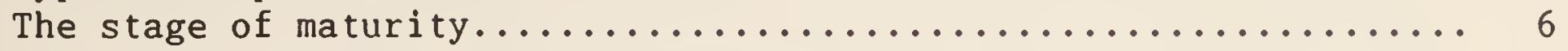

The effect of stage of maturity on the nutritional value

and yield of forage crops harvested under a two cut system....... 7

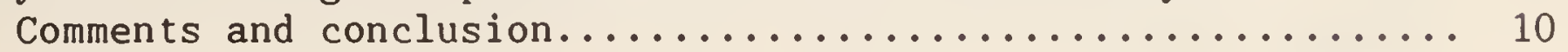

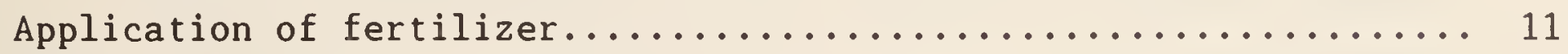

Harvesting and storing methods........................... 13

MOISTURE CONTENT AT HARVESTING.......................... 13

FORAGE CROPS FOR LIVESTOCK FEED IN THE ASPEN PARKBELT.............. 14

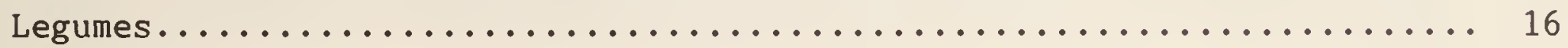

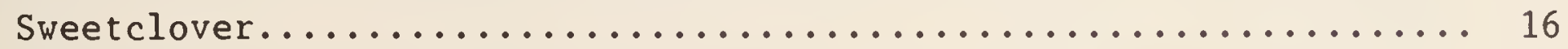

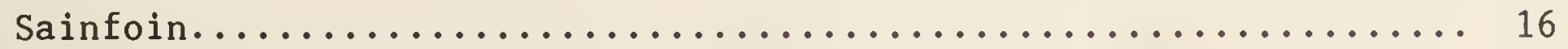

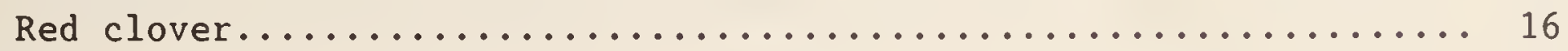

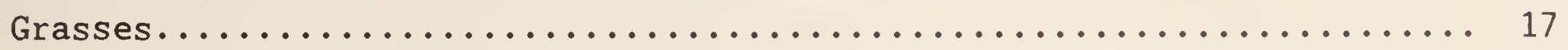

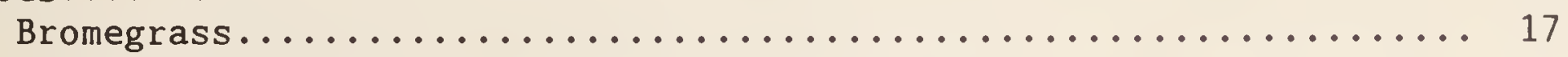

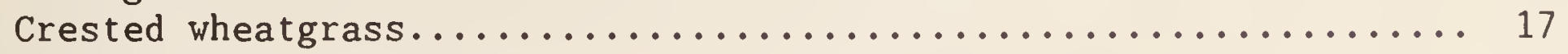

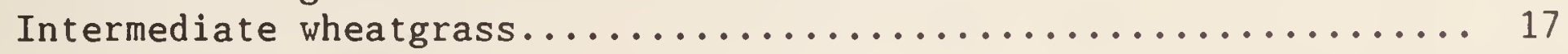

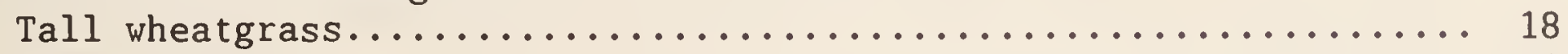

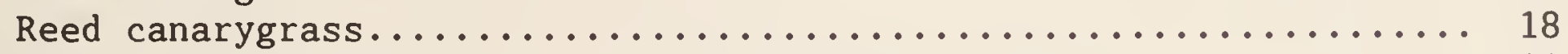

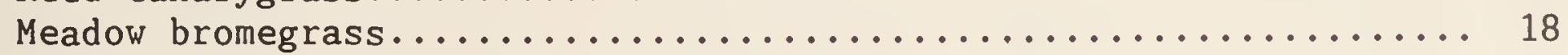

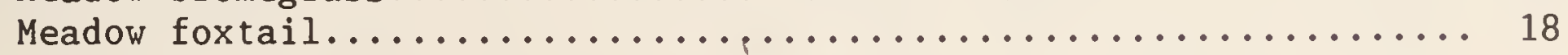

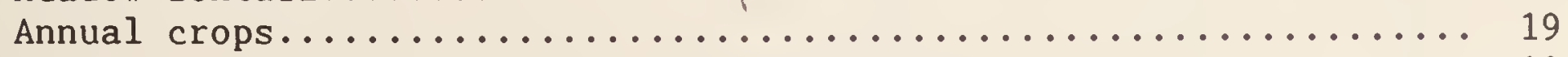

Summary......................................... 19

HOW MUCH FORAGE WILL VARIOUS CLASSES OF LIVESTOCK CONSUME?.......... 20

THE ROLE OF HARVESTED FORAGES IN MEETING THE NUTRITIONAL REQUIREMENTS

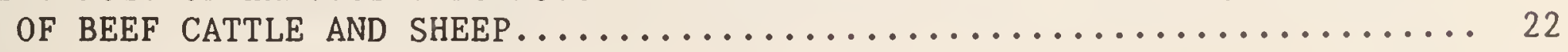

Nutritional requirements................................ 22

EFFECT OF FORAGE QUALITY ON THE EXTENT TO WHICH HAY AND SILAGE CAN MEET REQUIREMENTS OF BEEF CATTLE......................... 23

EFFECT OF LEVEL OF HAY CONSUMPTION ON GAINS OF BEEF CALVES......... 28

PROCESSING HAY FOR GROWING BEEF STEERS ................... 30 
EFFECT OF GRINDING HAY ON THE PERFORMANCE OF STEER CALVES FED FOR

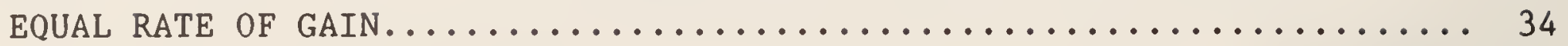

FACTORS AFFECTING THE ENERGY REQUIRED TO GRIND HAY.............. 35

FEEDING STEER CALVES FORAGE-BASED RATIONS.................... 37

A comparison of three grass hays fed to growing steer calves......... 37

Adding acidulated fatty acids (AFA) to a crested wheatgrass hay

and wheat rations for growing steer calves................... 38

Response of steer calves fed a ground crested wheatgrass ration,

to implantation with Ralgro and supplementation with acidulated

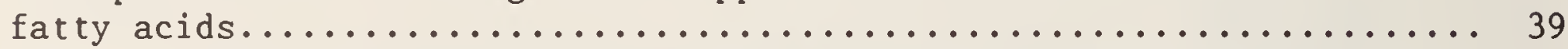

Effect of ammoniating hay on its feeding value for growing steers...... 40

Effect of supplemental grain, and of implanting, on the performance

of steer calves fed barley-silage..........................

FEEDING HEIFER CALVES FORAGE-BASED RATIONS ................. 43

Growing rations for beef heifers........................ 43

A comparison of forage-based vs grain-based rations for wintering

heifer calves..................................... 44

Crested wheatgrass vs brome-alfalfa fed unprocessed to growing

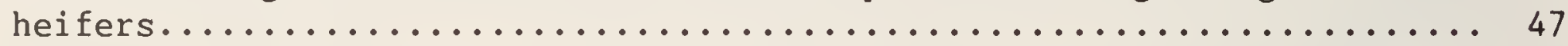

Feeding tall wheatgrass to growing heifer calves................ 47

The feeding value of several silages when fed to growing heifers...... 48

FINISHING BEEF STEERS AND HEIFERS ON FORAGE-BASED RATIONS .......... 50

Hay to grain ratio and the effect of hay quality in steer

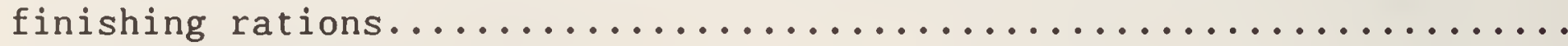

Adjusting from high-forage to high-grain rations for

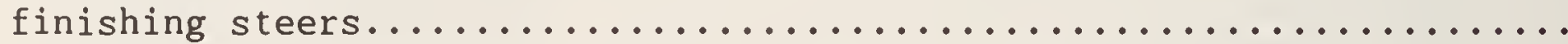

A comparison of several rates of reducing the level of ground

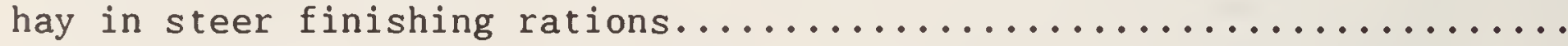

Adding acidulated fatty acids (AFA) to a ground, good quality hay

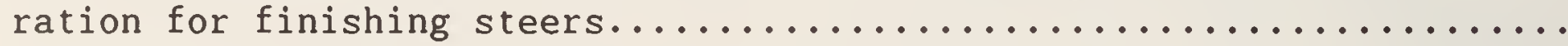

Effect of feed additives, high energy supplements and pelleting on

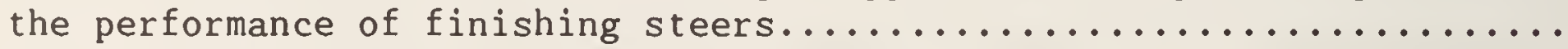

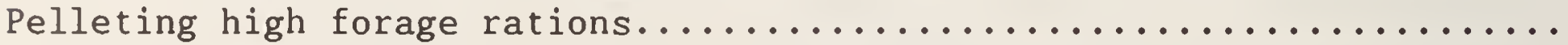

Finishing steers on a variety of forage based rations...............

Partially replacing ground alfalfa hay with straw or ammoniated

straw in a finishing ration for steers and heifers................

Implants and additives for beef cattle fed forage- and grain-

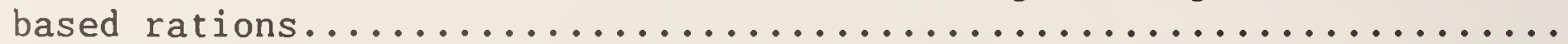

The effects of supplementing a growing-finishing ration for

steers and heifers, with several feed additives.................

TIPS ON UTILIZING GROUND HAY IN BEEF CATTLE RATIONS $\ldots \ldots \ldots \ldots \ldots \ldots$

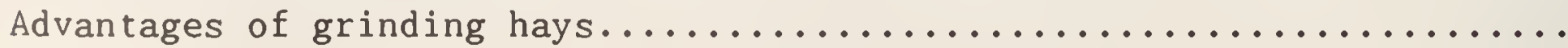

WINTERING BEEF COWS IN THE ASPEN PARKBELT................... 79 
FINISHING LAMBS ON FORAGE-BASED RATIONS .................... 84

Using good quality alfalfa in lamb finishing rations.............. 84

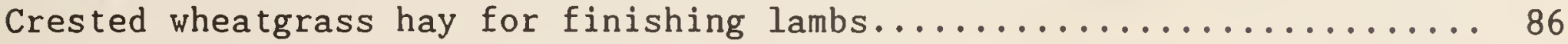

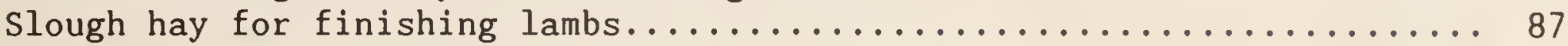

Effect of moistening on the feeding value of ground hays fed

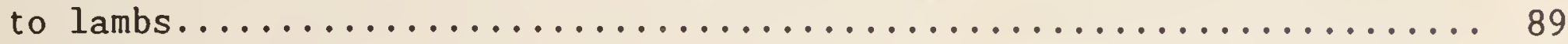

Effects of hay:grain ratio, molasses and linseed meal on performance

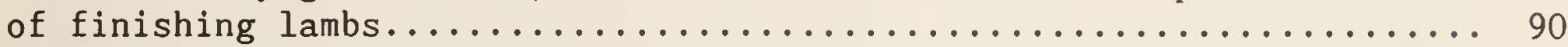

Voluntary intake and apparent digestibility of diets containing

varying levels of kochia hay, alfalfa hay and barley fed to sheep..... 91

Effect of feed additives, high energy supplements and pelleting

on the performance of finishing lambs fed forage-based rations....... 92

GENERAL GUIDELINES AND RECOMMENDATIONS FOR FINISHING LAMBS ON GROUND,

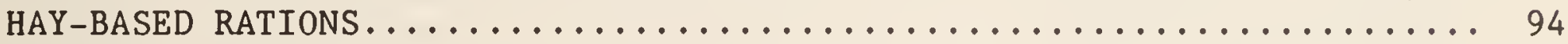

EFFECT OF RATIONS ON EATING QUALITY OF THE MEAT................... 95

Effect of ration, breed cross and implanting on the performance

of beef cattle and on the eating quality of the meal............. 95

Eating quality of forage and grain fed beef from steers and heifers..... 99

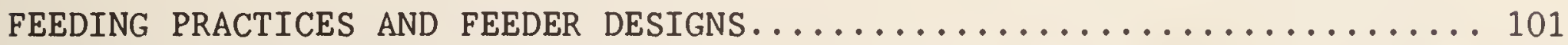

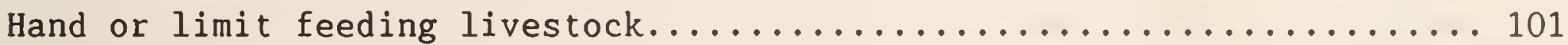

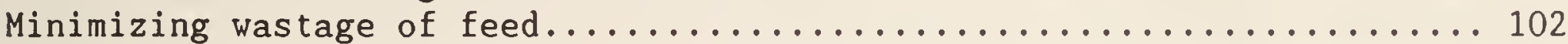

Handling and processing losses (estimate $0-22 \%) \ldots \ldots \ldots \ldots \ldots 2$

Losses during feeding (estimate $2-4 \%$ ).................... 102

Self-feeder for ground hay and/or grain-based rations for

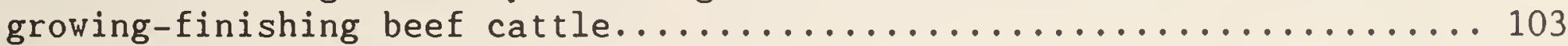

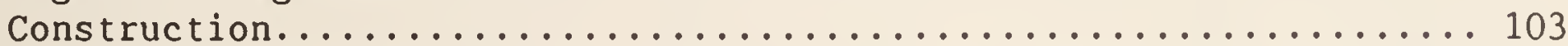

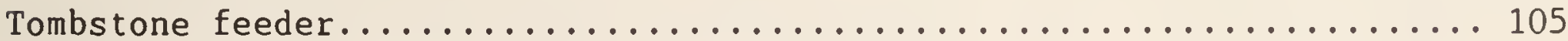

Standard, round bale and stack feeder........................ 107

"EFFICIENCY" OF BEEF PRODUCTION: FORAGE AND GRAIN REQUIRED TO

PRODUCE A UNIT OF DRESSED BEEF UNDER THREE FEEDING SYSTEMS . . . . . . . 107

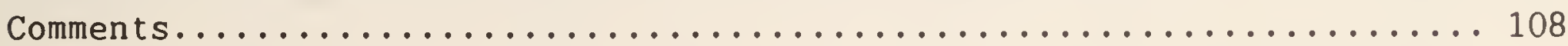




\section{FOREWORD}

As this publication is being prepared, the cattle industry is under attack by vegetarians and environmentalists. Beef consumption is being blamed for health problems ranging from heart disease to cancer. Run-off from feedlots is cited as a major cause of soil and water pollution. One "authority" says "cattle are responsible for $85 \%$ of top soil erosion". The production of methane gas in ruminants is now being blamed for a significant deterioration of the ozone layer, thus contributing to the "greenhouse effect". Cattle are being criticized for consuming grain that could be consumed by a rapidly increasing human population. 0thers blame the livestock industry for inefficient use of land.

In Western Canada it is hard to blame soil erosion on the cattle industry. Nearly every year, large areas of land used for the production of cereals and oilseeds (for human and livestock consumption) are damaged by wind or water erosion, while land devoted to the production of pasture and hay (solely for livestock feed) is only minimally affected (if at all!) by erosion. Soil salinity is far more prevalent on land used for the production of annual crops than on land permanently under perennial forage.

While grain could be used for feeding humans, the fact is that much of it is surplus to what can be marketed for human consumption and is fed to cattle to produce high quality milk and meat which more closely matches the nutritional requirements for humans and provides a highly palatable and desirable component of human diets.

One reason for developing efficient systems for the production and utilization of forage crops as pasture, hay and silage, over the years at the Melfort Station was in recognition of the fact that some day, grain and oilseed would have to be fed to humans, not livestock. Ruminant livestock would then play a vital and unique role in converting otherwise inedible forages (and other crop by-products) produced on land that was unfit for continual cultivation and on land where the use of soil-improving forage crops (particularly legumes such as alfalfa) was recognized as a key component of a cropping system in order to maintain or improve the crop production potential of the soil and thus contribute materially to a sustainable agriculture.

The senior author wishes to acknowledge his appreciation of the support and encouragement provided by $\mathrm{Dr}$. K. Rasmussen, former Animal Husbandman and later Director-General (Western Region), Research Branch, Agriculture Canada (now deceased); of Mr. Harold Wilson (now deceased), and Dr. W.N. MacNaughton, former Superintendent and Director, respectively, of the Melfort Station, in the development of the forage-beef research program. 


\section{ACRNOWLEDGMENTS}

The information in this publication summarizes some of the research on the utilization of forage crops conducted by the director and staff of the Melfort Research Station during the period 1961 to 1989. During this period, the Melfort station devoted a major part of its resources to developing a multidisciplinary approach to research on the forage/beef system, from the production of forages to the eating quality of the finished beef.

The following scientists conducted the research on forage processing and utilization, some of which is summarized in this publication.

S.E. Beacom, Ph.D. - Ruminant Nutritionist

$$
\text { - Director }
$$

E.Z. Jan, Ph.D., Engineer (Forage Systems)

Z. Mir, Ph.D., Ruminant Nutritionist

D.H. McCartney, Beef Cow-Calf Management Specialist

J.A. Robertson, Ph.D., Ruminant Nutritionist

S.0. Thorlacius, Ph.D., Ruminant Nutritionist
$1952-1989$

1966-1989 (Retired)

1976-present

1983-1987 (Now at Kamloops

Research Station)

1974-Present

1965-1985 (Now at Kamloops

Research Station)

1972-1980 (Decreased)

Appreciation is extended to the beef cattle herdsmen who, over the years, cared for the livestock in a conscientious manner and conducted the feeding trials with care and accuracy (Ab Fennell, Charlie Betts, Vic Choque, Clarence Baptist, Tim Wozniak, Gary Baraniski and Ray Clapson).

The dedicated efforts of the laboratory technicians who not only analysed feeds, feces, rumen contents, etc., but assisted in the allocation of experimental animals, weekly weighings and record keeping is gratefully acknowledged (Gordon McLachlan, Al Shaner, Carol Bonli and Brenda Sorensen).

In addition, the contribution of many university students who supervised and worked on livestock feeding trials during the summers has been very much appreciated.

The author also wishes to express his thanks to Dr. H.R. Davidson, current director of the Melfort Research Station for providing the secretarial help and other station resources involved in the preparation of this manuscript.

The author gratefully acknowledges the expert and dedicated efforts of Mrs. Susan Wittig, Secretary to the Director, Melfort Research Station, in deciphering the handwritten material and transforming it into an attractive finished product, and to the staff of the Program Research Services, Agriculture Canada, 0ttawa, for the printing of the final publication.

S.E. Beacom, Ph.D. 
Le rôle des cultures fourragères vivaces, et notamment des légumineuses, dans le maintien ou l'accroissement de la capacité productrice des terres agricoles est bien reconnu. Toutefois, dans un trop grand nombre de cas, les agriculteurs cultivent ces plantes comme solution de dernier recours dans des sols endommagés par l'érosion ou la salinisation, et souvent uniquement parce qu'une aide financière de l'État ou de la province les y incite. Voilà une triste observation qui s'applique à un grand nombre de ceux qui "gèrent" la plus importante ressource naturelle du Canada, que nous osons espérer renouvelable.

Malheureusement, dans la conjoncture actuelle, certains agriculteurs ne peuvent voir quel avantage leur procurerait à long terme sur le plan financier le fait d'incorporer des cultures fourragères dans leur système cultural pour empêcher leurs terres de se détériorer ou de devenir entièrement stérile. Il est donc essentiel de perfectionner les techniques de culture, de récolte, de conservation et d'utilisation des fourrages de manière à ce que cette production devienne aussi rentable, sinon plus, que la production des cultures dites commerciales sur les terres marginales et à ce qu'elle constitue à court terme un élément souhaitable de la rotation culturale même sur les terres les plus productives.

La présente publication récapitule les travaux réalisés de 1954 à 1989, à la Station de recherches de Melfort, sur l'utilisation des fourrages fauchés pour l'engraissement et la finition des bovins de boucherie. L'auteur s'est limité aux recherches menées à cette seule station pour deux raisons, la première étant l'abondance du matériel disponible, et la seconde, le fait que presque tous les travaux effectués dans ce domaine dans 1'ouest du Canada l'ont été à cette station. Ces recherches s'inscrivaient dans le mandat confié à la station en 1954, soit d'entreprendre sur ses terres noires productives un programme exhaustif de recherches sur les pâturages. Cependant, il est vite devenu évident qu'il serait plus logique d'utiliser pour la production de pâturage les terres moins productives et plus difficiles à travailler, et de réserver les terres plus fertiles à la production des fourrages de conservation - le foin et l'ensilage (et peut-être au pâturage de fin d'été) - pour 1'alimentation des vaches d'élevage de boucherie et de leur descendance au cours du long hiver typique de la prairie-parc.

Dans bon nombre des essais dont nous faisons état ici, nous avons essayé de déterminer la rentabilité relative des traitements employés pour un rapport coût - prix donné et en prenant en compte uniquement les coûts variables établis. Dans 1a plupart des cas, la quantité d'information fournie est suffisante pour permettre un nouveau calcul de la rémunération du travail en attribuant aux variables leurs valeurs actuelles (ex. : coûts des aliments du bétail, valeur de la carcasse, etc.). Il n'est pas tenu compte cependant de la valeur de la culture fourragère comme moyen d'améliorer la productivité des terres en les protégeant contre l'érosion, etc., ni de la restitution d'éléments nutritifs au sol sous forme de déchets animaux et de litière. 
Le principal objectif du programme d'élevage de la Station de Melfort était d'optimiser l'utilisation des plantes fourragères dans la production des bovins à viande, de façon à produire des carcasses de catégorie supérieure et de la viande présentant de bonnes qualités gustatives. Il importe également de favoriser l'accroissement de la production de fourrages afin de contribuer au maintien et à l'amélioration du potentiel de production de nos terres, en particulier de celles dont la fertilité est faible et de celles qui sont très productives, mais que l'érosion tant éolienne qu'hydrique détériore petit à petit parce qu'on y cultive trop de plantes qui épuisent le sol, parce qu'on y applique de mauvaises pratiques agronomiques, ou encore, parce qu'elles sont trop souvent laissées en jachère. Pour inciter les producteurs de grains à faire pousser des cultures fourragères surtout sur les terres hautement productives, il est essentiel de trouver des débouchés pour ces fourrages à l'extérieur de la ferme. Puisque les secteurs du naissage et de la production des veaux d'engrais utilisent déjà une forte proportion de fourrages, le secteur où il semble logique d'étendre l'emploi des fourrages coupés est celui de 1 'engraissement des bovins.

La présente publication a pour objet de fournir de l'information aux éleveurs de bovins de boucherie, aux agronomes et aux étudiants qui s'intéressent à l'emploi, dans l'alimentation des bovins de boucherie, des plantes fourragères vivaces cultivées à la ferme. On y soulignera l'importance de produire du foin et de l'ensilage de bonne qualité, les facteurs déterminant la qualité de ces fourrages ainsi que les techniques dont dispose le producteur pour améliorer la valorisation des fourrages par les bovins de boucherie. 



\section{INTRODUCTION}

The role of perennial forage crops, particularly legumes, in maintaining or improving the productive capacity of agricultural soils, is well recognized. However in too many cases, forage crops are seeded as a last resort on soils damaged by erosion or salinity, and often only because the farmers involved are given financial support from governments. This is a sad commentary on many of those who are "managing" Canada's most important natural and, hopefully, renewable resource.

Unfortunately, under current conditions, some farmers cannot see the. long term financial advantage of incorporating forage crops into their cropping systems to protect their land from deteriorating or even from becoming totally unproductive. It is thus essential that the technology for growing, harvesting, storage and utilization of forage crops be developed to, and beyond, the point where forage crops offer the farmer a viable economic alternative to so-called cash crops on their marginal soils and constitute a desirable component of their crop rotation even on the most productive soils in the short run.

This publication summarizes the work done on utilizing harvested forages primarily for growing-finishing beef cattle, at the Melfort Research Station during the period from 1954 to 1989. The material is limited to work done at the Melfort Station for two reasons. One, there is a lot of material. Secondly, most if not all of the research in this field in western Canada has been done by the staff at the Melfort Station. This work was a natural development of our mandate in 1954 to undertake an extensive pasture research program on the productive Black soil at the Melfort station. It soon became obvious that pasture production was more logically carried out on the more-difficult-to cultivate soils of lower inherent productivity and that more productive soils would be better utilized for the production of harvested forages - hay and silage (and possibly for late summer pasture) for the feeding of the beef cow herd and its progeny during the long winter feeding period, typical of the Aspen parkbelt.

In a number of trials reported here, we have attempted to determine the relative economics of the treatments, under a given cost/price situation and assuming only the variable costs listed. Enough information is given, in most cases, to permit a recalculation of the returns to labor by substituting current feed costs, carcass values, etc.. No account is taken of the value of the forage crop in improving the productive capacity of the soil by preventing erosion, etc., or of the return of nutrients to the soil in the form of animal wastes and bedding.

The main objective of the Melfort Research Station's livestock program was to maximize the use of forage crops in beef cattle production, consistent with the production of high grading carcasses and good eating quality of the meat. It is also important to encourage more forage crop production to assist in maintaining and improving the productive potential of our soils, particularly those that are of inherently low productivity and those highly 
productive soils that are being ruined through wind and water erosion as a result of growing too many soil depleting crops, poor agronomic practices and/or the use of too much summerfallow. If grain producers are to be encouraged to grow forage crops, particularly on highly productive land, it is imperative that off-the-farm markets be developed for these forages. Since the cow-calf and feeder calf sectors already use a high proportion of forage crops, the logical area for the expanded use of harvested forage crops is in the feedlot finishing area.

The purpose of this bulletin is to provide information to beef cattle producers, agrologists and students interested in the use of farm-grown perennial forage crops for beef cattle production. The importance of producing good quality hay and silage, the factors affecting hay and silage quality and the techniques available to improve the efficiency of converting forages into beef will be presented.

\section{FORAGE QUALITY}

Harvested forages normally consist of the whole, above-ground, portion of the plant, unlike grain, that comprises only one portion of a mature crop. Because of this and the fact that forage crops are harvested over a wide range of maturity, the physical and chemical composition of forages varies much more than does that of grain. Table 1 shows the chemical analyses of some typical forage crops in the Aspen Parkbelt, and the ranges in composition that can occur within the crop species. The data emphasize two important points. There is an extremely wide range in protein and energy content of forage crops both between and within the same species. It is thus important that the livestock feeder have feeds analysed in order to make effective use of them in formulating rations. The range in feeding value also indicates that there must be important reasons for these marked differences and that the forage producer, once he is familiar with them, should be able to exercise some control over the quality of his forage. 
Table 1. Typical analyses of some common forages in the Aspen Parkbelt (\%) (range)

$\begin{array}{ccc}\text { Crude } & \text { Total } & \text { Acid } \\ \text { protein } & \text { digestible } & \text { detergent } \\ (\mathrm{N} \times 6.25) & \text { nutrients } & \text { fibre }\end{array}$

Calcium Phosphorus

Hays

$\begin{array}{lccccc}\text { Alfalfa } & 16 & 53 & 32 & 1.6 & 0.2 \\ \text { Clover } & (7-22) & (46-60) & (22-48) & (0.6-2.6) & (0.1-0.3) \\ \text { Alfalfa-brome } & 13 & 49 & 37 & 1.2 & 0.2 \\ & (7-19) & (43-58) & (23-51) & (0.5-1.8) & (0.1-0.4) \\ \text { Bromegrass } & 12 & 52 & 34 & 1.0 & 0.2 \\ & (7-19) & (43-58) & (22-45) & (0.4-1.9) & (0.1-0.3) \\ \text { Crested wheatgrass } & 9 & 50 & 36 & 0.6 & 0.2 \\ & (4-14) & (45-56) & (31-38) & (0.2-1.0) & (0.1-0.2) \\ \text { Oat hay } & 10 & 51 & 35 & 0.6 & 0.1 \\ & (6-12) & (44-59) & (27-46) & (0.2-0.7) & (0.1-0.2) \\ \text { Silage } & (5-15) & (39-57) & (23-47) & (0.1-0.7) & (0.1-0.4) \\ \text { Alfalfa } & 14 & & & 0.2 \\ & (8-22) & (45-59) & (30-50) & (0.7-2.3) & (0.1-0.3) \\ \text { Clover } & 14 & 51 & 37 & 1.2 & 0.2 \\ \text { Barley } & (12-18) & (47-57) & (29-52) & (0.9-1.5) & (0.1-0.3) \\ & (6-18) & (45-58) & (24-44) & (0.2-0.7) & (0.2-0.4)\end{array}$

Forage quality is a measure of the forages' ability to effectively meet the nutritional requirements of a particular class of livestock, either as the major component of the ration or in combination with other ration ingredients. In evaluating forages, several criteria are assessed - chemical composition, physical attributes and palatability. of these, chemical composition is the easiest to determine, while palatability requires that feeding trials be conducted with the class of animal for which the forage is intended.

Chemical composition is determined in the laboratory. Crude protein (CP) and total digestible nutrients (TDN) are of prime importance. Because forages contain little fat or oil, digestible organic matter (DOM) is closely related to TDN. One or more measurements of fibre content (such as acid detergent fibre, ADF) are sometimes carried out and are much more important 
in assessing feeding value for non-ruminants than for ruminants, because of the microflora in the rumen, which can usually utilize fibre quite effectively, depending on the amount and distribution of lignin in the fibrous tissue.

Analyses for minerals, particularly calcium and phosphorus, are normally carried out. However, in practice, average levels are assumed and livestock given free access to salt and appropriate mineral mixes. In the case of forage-fed livestock, provision of supplemental phosphorus is particularly important as forages, as a class, are low in phosphorus.

Physical factors such as color, odor, leafiness and leaf:stem ratio, while subjective, can provide the experienced feeder with a reasonably reliable indication of feeding value and to some extend acceptability by livestock. Moldiness, contamination with weeds, dust and other debris, also provide indications of forage quality.

Some forages contain chemical compounds that can render their use harmful to livestock regardless of their nutrient content. Reed canarygrass (unless a low alkaloid variety), particularly lush, fertilized pasture, can contain alkaloids which adversely affect feed intake and animal performance (particularly with sheep), moldy sweetclover can contain dicoumerol which can lead to hemorrhaging, and drought or frost-stressed oats can contain toxic ?. als of nitrates. In addition, some legumes, particularly alfalfa, will cause bloat under some conditions, which can negate the advantages of this crop's high feeding value and its nitrogen fixing ability in specific situations.

Acceptability or palatability, measured in terms of how much the animal will consume, is the most important factor in determining the feeding value of a forage. Coarse, moldy, dusty, or weedy feeds may contain enough protein or energy to theoretically meet the nutrient requirement of the animal, but unless the animal finds it palatable, it will not be consumed at levels required to ensure efficient utilization. Even some palatable feeds (eg. high moisture silage) may not be consumed in sufficient quantities for efficient production because of their bulkiness in relation to the physical capacity of the rumen and/or a slow rate of digestion, which limits intake. The effect of forage quality on feed intake is illustrated in Table 2 .

Table 2. Effect of forage quality on feed intake*

\begin{tabular}{lccc} 
Hay quality & $\begin{array}{c}\text { Digestibility } \\
(\%)\end{array}$ & $\begin{array}{c}\text { Hours in } \\
\text { rumen }\end{array}$ & $\begin{array}{c}\text { Relative } \\
\text { feed intake }\end{array}$ \\
\hline Poor & 45 & 83 & 100 \\
Medium & 59 & 55 & 153 \\
Good & 74 & 41 & 186 \\
\hline
\end{tabular}

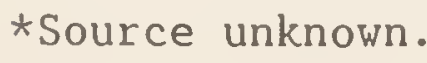


For most livestock producers, choice of crop will be based on the soil and climate conditions prevailing on their farm. Such factors as soil pH, salinity, susceptibility to flooding and the normal moisture supply during the growing season will determine the forage species which will produce the most nutrients per unit of land. However, within acceptable species there may be some choice of crop which will provide better quality than others.

Generally speaking, legume crops such as alfalfa, clover, sainfoin, faba beans and peas contain considerably more crude protein, calcium and carotene than grasses such as bromegrass, crested wheatgrass and timothy when harvested at comparable stages of maturity.

With silages, quality not only depends on the initial level of nutrients in the crop but on the dry matter content at harvesting and the fermentation process. Crops that are very high in protein and thus relatively lower in soluble carbohydrates may not ensile as well as those with a higher carbohydrate:protein level. However this is not always the case. An experiment carried out over three successive years at Melfort, compared silages made from faba beans, field peas, oats and corn. Corn was harvested in the milk stage, the other crops in the dough stage. The results are presented in Table 3.

Table 3. Value of annual crop silages fed to lambs

Faba beans Field peas 0ats Corn

\begin{tabular}{|c|c|c|c|c|}
\hline Dry matter yield ( $\mathrm{kg} / \mathrm{ha})$ & 8670 & 8089 & 7809 & 9332 \\
\hline$\%$ Dry matter at ensiling & 29.8 & 32.0 & 33.4 & 29.5 \\
\hline$\%$ Crude protein (of DM) & 19.8 & 18.7 & 9.0 & 9.9 \\
\hline Average daily dry matter eaten $(g)$ & 1084 & 1004 & 698 & 602 \\
\hline Average daily gain (g) & 169 & 148 & 25 & -9 \\
\hline Digestibility of dry matter $(\%)$ & 67.8 & 69.7 & 60.7 & 65.0 \\
\hline Liveweight gain per ha $(\mathrm{kg})$ & 1351 & 1194 & 280 & -139 \\
\hline
\end{tabular}

The results indicate not only the wide difference in protein content between these crops, but the importance of intake of nutrients on the efficiency of crop utilization by livestock.

Another test carried out with growing beef heifer calves compared the feeding value of four different crops put up as silage. The results are shown in Table 27 in another section of this publication. They show that 
even crops with more than adequate levels of crude protein can differ markedly in their feeding value.

\section{The stage of maturity}

Perhaps more than any other factor, the stage of maturity at which the forage is grazed or harvested as hay or silage, influences its feeding value. Generally speaking, the crude protein content, leaf:stem ratio, digestible energy content (except for corn for silage), calcium and carotene levels will decrease with increasing plant maturity; dry matter yield will increase to the early bloom stage with legumes and grasses and to the early dough stage for cereals and then declines; while the crude fibre content increases with advancing maturity.

The economic importance of good quality forage for high producing livestock is appreciated when it is realized that considerable, usually high-priced, grain is required to obtain good production when forage quality is inadequate.

In general, TDN levels of forage drop about $1 / 2 \%$ for each day that cutting is delayed past the half-bloom stage. Similarly intake drops by $1 / 2 \%$ per day. Thus in total, there is a $1 \%$ drop in feeding value daily, past the early bloom stage.

While the most nutritious stage of growth of forage crops is in the early vegetative stage there must be, in practice, a compromise between yield and quality. The relative importance of quality and yield will depend on the kind of livestock operation involved and on the availability of other feeds. For example, a cow-calf operator depending entirely on harvested hay for his winter feed supply will probably harvest his forage at the full bloom stage in order to maximize yield. For most forages this will still provide the $7-9 \%$ crude protein level required by the wintering cow. If his cows calve in late winter-early spring, he would be wise to put up some higher quality hay to meet the increased nutrient requirements of his cows following calving and perhaps some even higher quality legume hay to creep feed to his calves until they are able to go to pasture.

If on the other hand, the cow-calf operator has an abundant supply of cereal straw available and some grain, he may opt for harvesting his alfalfa at the early or even pre-bloom stage and aim for a second cut at the same stage of maturity. In this instance he will be using the high protein hay as a supplement to straw and some grain and avoid the need to purchase costly protein supplements. 
The effect of stage of maturity on the nutritional value and yield of forage crops harvested under a two cut system

It is generally recognized that perennial forage crops have a high percentage of crude protein and digestible energy at the start of the growing season and that these percentages progressively decrease as the plant matures to the ripe seed stage and beyond. It is, of course, also recognized that the yield of plant dry matter per unit of land increase up to a point, as the plant matures, and then declines due to the physical loss of mature or dead leaves, flower parts, seed, etc.. There is a point (or stage of development) where the increasing plant yield does not compensate for the reduction in plant quality and at this point there is no logical reason to delay harvesting the crop for hay or silage. Where a second cut of hay is possible, there is also the need to know the optimum timing of the first cut to permit a second cut of optimum yield and quality. The longer the delay in taking off the first cut, the lower will be the yield of the second cut, but the higher will be its quality (or digestible nutrient content).

To answer some of these questions, an experiment was carried out using existing hay stands of seven different forage species, all grown on the same soil type under the same climatic conditions. Areas within each forage stand were harvested at weekly intervals running from May 15 to August 21. On August 21 all previously harvested plots with a harvestable yield were reharvested to determine yield and quality of the "second cut".

In the previous fall, soil moisture reserves were normal and this, along with good snowfall provided a good start to crop growth in the spring. Rainfall during the growing season was $182.3 \mathrm{~mm}$.

The results are shown in the accompanying graphs. Figure 1 shows two graphs for three of the most common forages, since trends were similar for all seven forages. On the left hand side is shown the yield curve for the first cut and the yield curve for the two cuts combined on the right side are the curves showing the trends for crude protein and digestible organic matter percentages for the first cut.

Figure 2 displays the curves showing the total crude protein yield $(\mathrm{kg} / \mathrm{ha})$ for the seven species under the two cut harvesting system. Figure 3 shows the yield of digestible organic matter $(\mathrm{kg} / \mathrm{ha})$ for each of the harvesting dates. 
ALFALFA

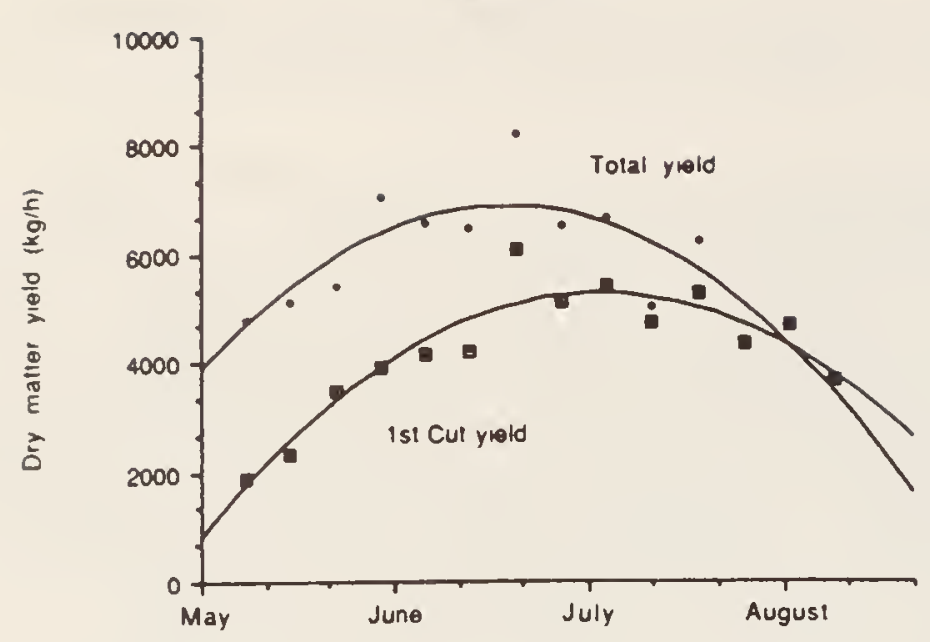

BROMEGRASS

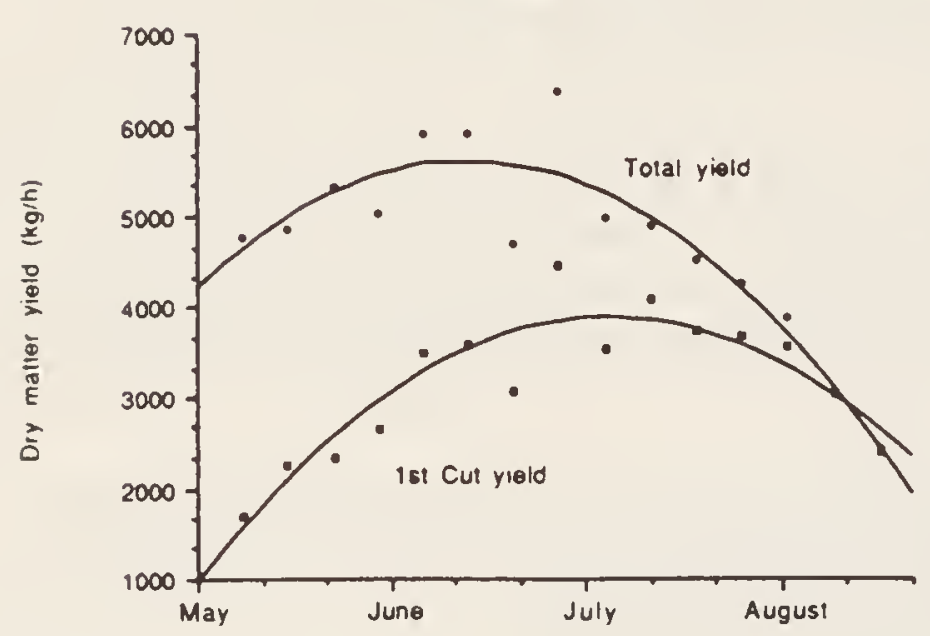

CRESTED WHEATGRASS

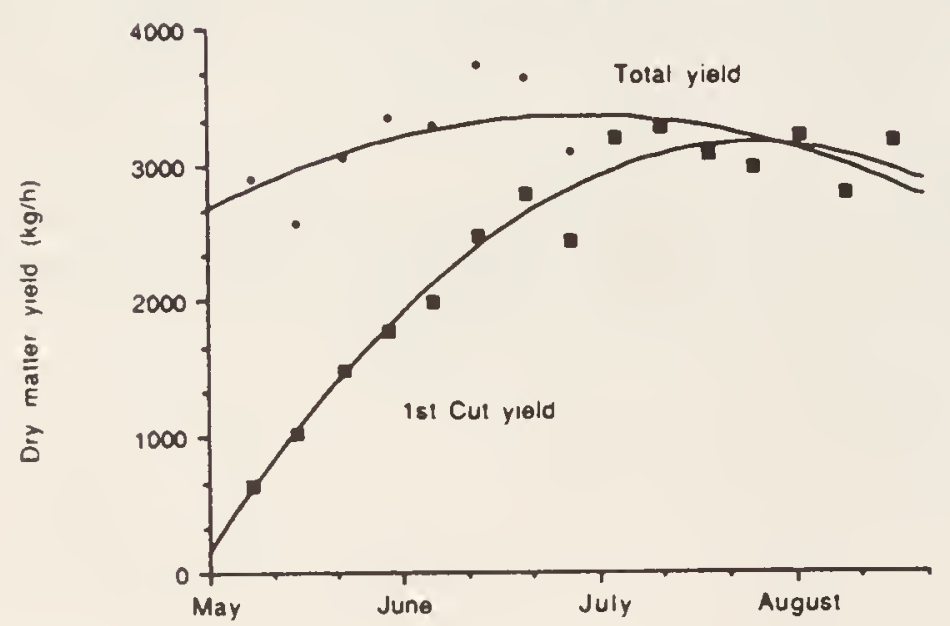

ALFALFA - FIRST CUT

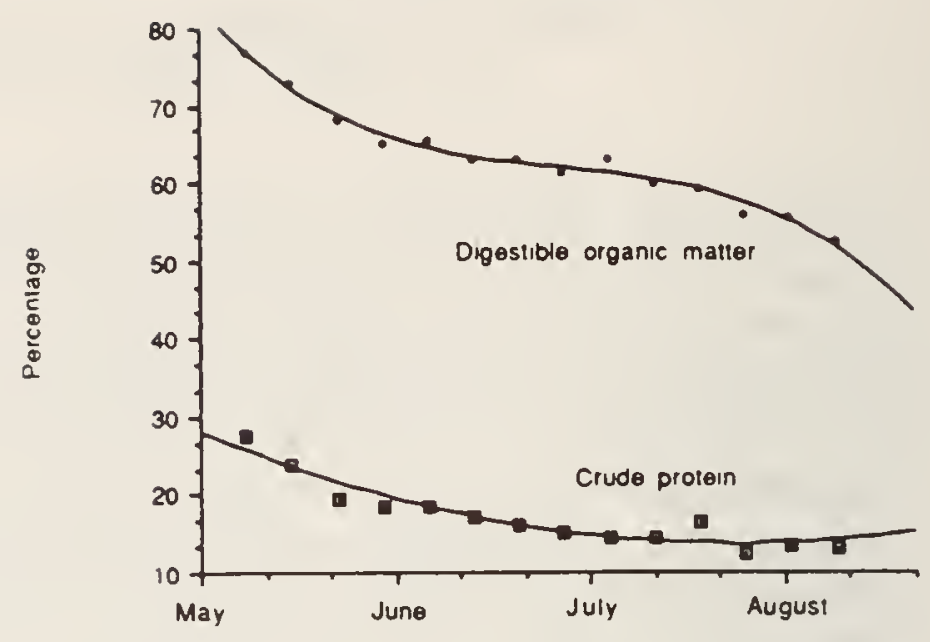

BROMEGRASS - FIRST CUT

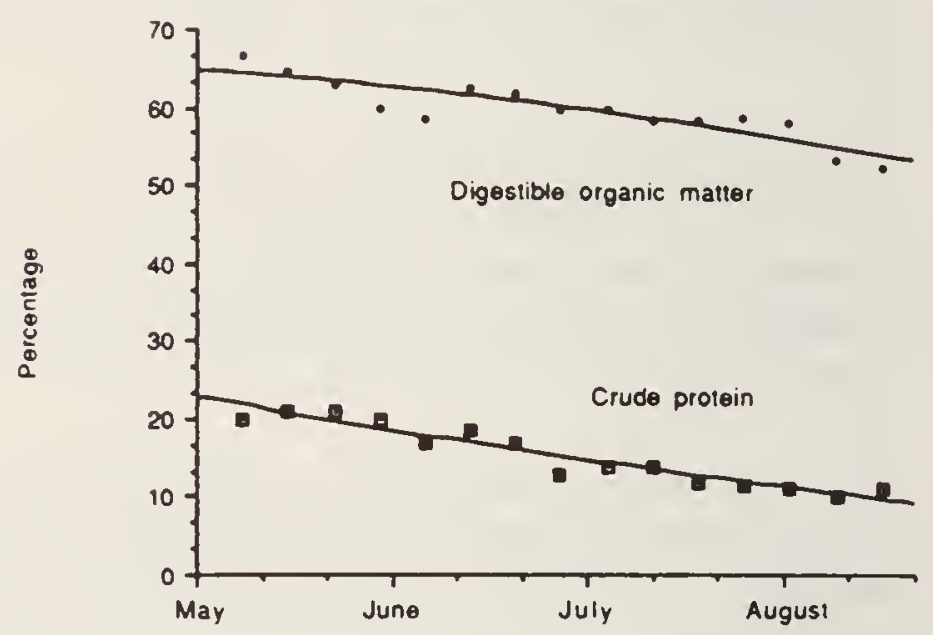

CRESTED WHEATGRASS - FIRST CUT

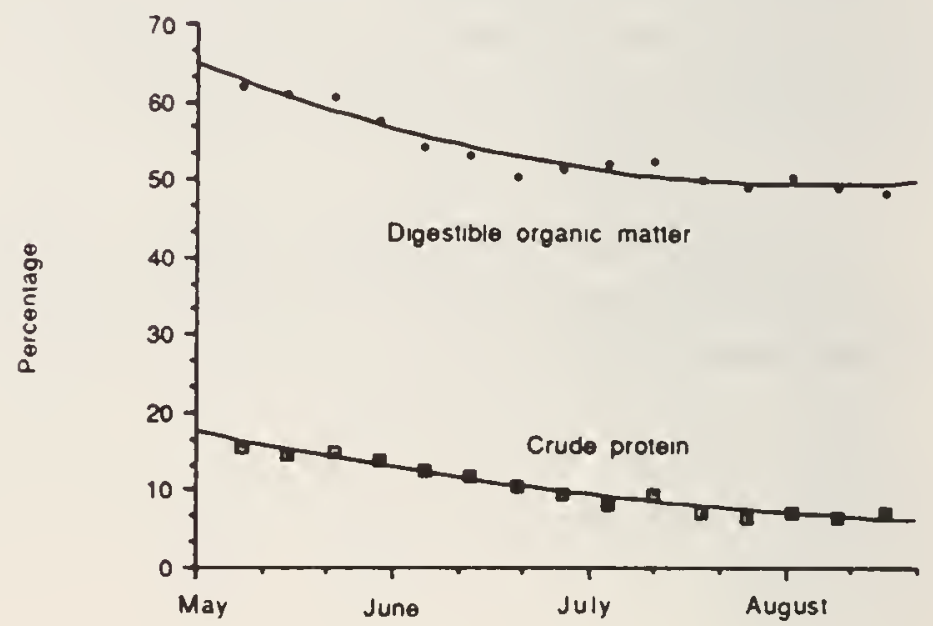

Fig. 1. Dry matter production (first cut and total) left, and trend in crude protein and digestible organic matter contents of the first cut, for three forage species harvested at weekly intervals (second cut was harvested August 21). 


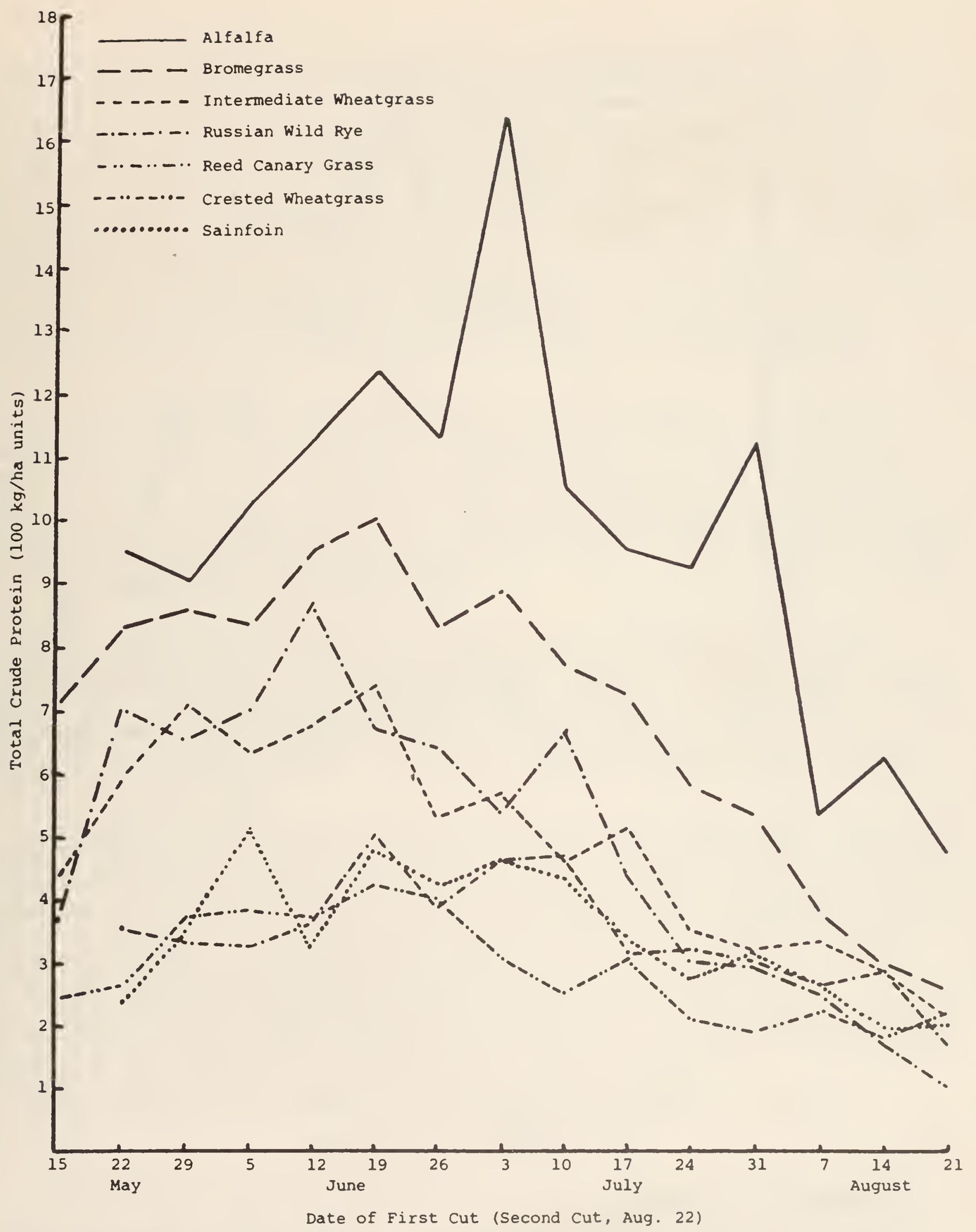

Fig. 2. Total yield of crude protein under a two-cut system. 


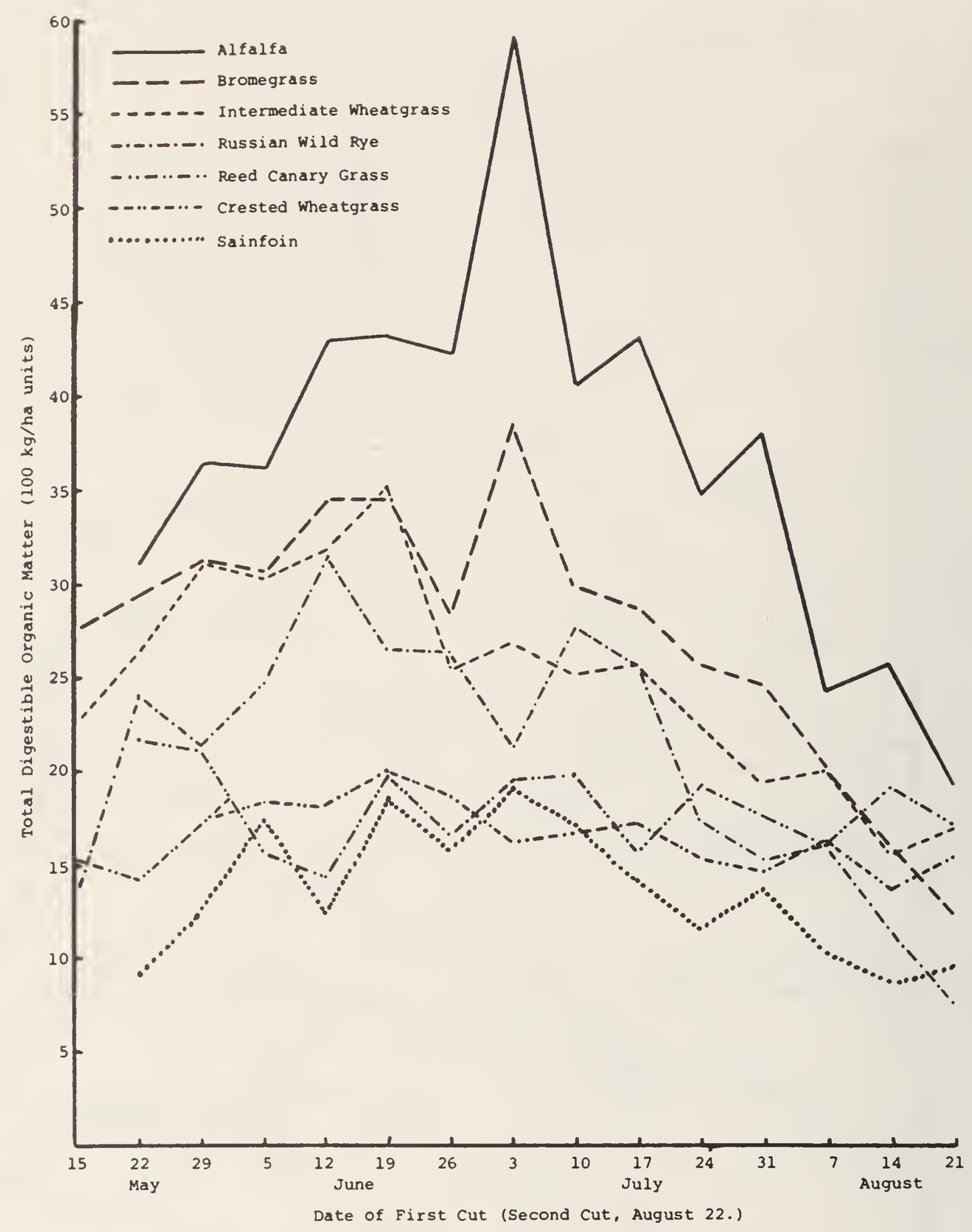

Fig. 3. Total yield of digestible organic matter ( $\mathrm{kg} / \mathrm{ha}$ ) under a two-cut system.

\section{Comments and conclusions}

1. Because these stands were of different ages and perhaps on soil of differing fertility levels, it is not valid to compare yields between species. 
2. It is confirmed that, in general, both crude protein and digestible organic matter levels, decrease with maturity. On average, crude protein fell from about $21.5 \%$ in the first week harvested to 12.6 , with some species dropping 14 to 15 percentage points (alfalfa, IWG, sainfoin, RWR) while others (CWG and brome) dropped 8-9 percentage points over the 14 week test. Digestible organic matter trends somewhat paralleled crude protein declines, with the exception that sainfoin maintained its DOM level with little decline from mid-June to early August. On average, DOM levels fell by 18 percentage points with alfalfa and RWR dropping about 25 percentage points and brome, CWG and reed canarygrass dropping, on average, 14 percentage points, over the 14 weeks. It is interesting that RWR, reputed as being able to maintain its feeding value well into the grazing season, in southern Saskatchewan, suffered big drops in both $\mathrm{CP}$ and DOM content as the season progressed.

3. Total yield of crude protein per ha was maximized for all but one of the grasses (RWR, June 12) when the first cut was taken on June 19 (all second cuts were taken August 31 ). Maximum production of alfalfa occurred when the first cut was taken July 3, while for sainfoin, this occurred on June 5. Yield of DOM for alfalfa, sainfoin and bromegrass was maximized when the first cut was taken on July 3. Maximum DOM yields for reed canarygrass, RWR, CWG and IWG were obtained when the first cut was taken on May 22, June 12, June 19 and June 19 , respectively.

Obviously stage of maturity rather than calendar date is the most logical criterion with respect to optimum cutting time and this will be considerably affected by growing conditions. This experiment showed, rather dramatically, that for optimum yield of digestible nutrients, stands of all species tested should be harvested much earlier than is done in normal practice, even under a single cut system, ranging from the early heading to the early bloom stage.

Dry matter yield curves for first cut and total yield (two cuts) for reed canarygrass differed from those of the other grasses in the test in that yield continued to increase with stage of maturity, and total yield, while variable with respect to date of first cut, is generally maintained over the season irrespective of cutting date, except that cutting from late May to early June appears to depress total yield.

Total yield of crude protein increased until the first harvest was taken in mid-July and then fell off, while for the other grasses the decline had begun when the first cut was made between June 5 to June 19.

\section{Application of fertilizer}

Application of nitrogen fertilizer can have an effect on the protein content of forage crops, although under most circumstances, the effect is evidenced by an increase in yield. An experiment carried out at the Brandon Research Station determined the effect on both yield and crude protein content of applying three different amounts of $\mathrm{N}$ in the first year of a three 
year study (Table 4). Only in the first year is there enough excess nitrogen to increase protein level. Applying excess nitrogen to increase protein content is probably not a sound practice. Excess $\mathrm{N}$ could be lost from light to sandy soils through leaching or erosion.

However when leaching is not a problem, there may be some situations where applying more than one year's supply of nitrogen fertilizer would have merit.

Table 4. Effect of nitrogen fertilizer on yield and protein content of hay at Brandon

\begin{tabular}{|c|c|c|c|c|c|c|}
\hline \multirow[b]{2}{*}{$\mathrm{N}$ fertilizer } & \multicolumn{3}{|c|}{ Hay Yield ( $\mathrm{kg} / \mathrm{ha})$} & $\mathrm{DM} / \mathrm{kg}$ & \multicolumn{2}{|c|}{ Crude Protein } \\
\hline & Year 1 & Year 2 & Year 3 & of $N(\mathrm{~kg})$ & $\overline{\text { Year } 1}$ & Year 2 \\
\hline 0 & 3980 & 1770 & 1907 & -- & 11 & 12 \\
\hline 84 & 6272 & 2072 & 1789 & 29 & 13 & 11 \\
\hline 169 & 8019 & 2183 & 2183 & 30 & 15 & 12 \\
\hline 253 & 8910 & 3606 & 2541 & 29 & 16 & 12 \\
\hline
\end{tabular}

*Applied in first year only.

Source: Brandon Research Station

The effect of applying phosphorus, potassium and sulfur to nutrient deficient soils in Manitoba, on the yield and protein content of alfalfa is shown in Table 5 .

Table 5. The effect on Yield and protein content of alfalfa from applying fertilizer on nutrient deficient soils of Manitoba

\begin{tabular}{|c|c|c|c|c|c|c|c|c|}
\hline \multicolumn{3}{|c|}{ Phosphorous $\left(\mathrm{P}_{2}, 0_{5}\right)$} & \multicolumn{3}{|c|}{ Potassium } & \multicolumn{3}{|c|}{ Sulfur } \\
\hline $\begin{array}{l}\text { Rate } \\
\text { (kg/ha) }\end{array}$ & $\begin{array}{l}\text { Yield } \\
\text { (t/ha) }\end{array}$ & $\begin{array}{c}\text { Protein } \\
(\%)\end{array}$ & $\begin{array}{l}\text { Rate } \\
(\mathrm{kg} / \mathrm{ha})\end{array}$ & $\begin{array}{l}\text { Yield } \\
\text { (t/ha) }\end{array}$ & $\begin{array}{l}\text { Protein } \\
(\%)\end{array}$ & $\begin{array}{l}\text { Rate } \\
(\mathrm{kg} / \mathrm{ha})\end{array}$ & $\begin{array}{l}\text { Yield } \\
\text { ( } t / \text { ha })\end{array}$ & $\begin{array}{l}\text { Protein } \\
(\%)\end{array}$ \\
\hline 0 & 5.0 & 11.3 & 0 & 3.3 & 9.4 & 0 & 3.6 & 8.8 \\
\hline 23 & 6.1 & 12.5 & 56 & 6.4 & 12.5 & 17 & 6.2 & 11.3 \\
\hline 45 & 10.2 & 13.8 & 84 & 8.3 & 17.5 & 34 & 9.6 & 18.8 \\
\hline 67 & 12.5 & 20.0 & 112 & 10.6 & 20.0 & 51 & 12.0 & 20.6 \\
\hline 112 & 11.2 & 18.8 & 224 & 10.0 & 21.2 & 67 & 11.7 & 21.3 \\
\hline
\end{tabular}

Source: L. Bailey, Brandon Research Station 


\section{Harvesting and storing methods}

Another factor having a major effect on forage quality or feeding value is the method used to package and store the forage. The goal must be to minimize leaf loss and exposure to weathering. Forage for hay should be cut, conditioned and windrowed in one operation to avoid raking, and packaged or otherwise removed to storage at the optimum moisture level for the operation involved. Results of an experiment carried out at Melfort to determine the effect of cutting and windrowing methods on the feeding value of the forage are shown in Table 6. (Note: A companion bulletin on "Forage Harvesting in the Aspen Parkbelt of Western Canada" contains considerable information on the effect of harvesting and storage systems on the feeding value of forages.)

Table 6. Effect of cutting method on feeding value of brome-alfalfa hay* fed to lambs

\begin{tabular}{lcccc}
\hline & \multicolumn{3}{c}{ Cutting Treatments } \\
\cline { 2 - 5 } & $\begin{array}{l}\text { Mow \& } \\
\text { rake }\end{array}$ & $\begin{array}{l}\text { Mow-cond. } \\
\text { swath-rake }\end{array}$ & $\begin{array}{c}\text { Mow-cond. } \\
\text { windrow }\end{array}$ & $\begin{array}{c}\text { S.P. cond. } \\
\text { swather }\end{array}$ \\
\hline $\begin{array}{l}\text { Average daily gain (kg) } \\
\text { Average daily feed (kg) }\end{array}$ & 0.16 & 0.16 & 0.18 & 0.19 \\
Liveweight gain/tonne of & 1.43 & 1.42 & 1.43 & 1.49 \\
$\begin{array}{l}90 \% \text { DM ration (kg) } \\
\text { Relative value of hay, \$/tonne }\end{array}$ & 713 & 110 & 121 & 124 \\
\hline
\end{tabular}

*Ground hay $(0.8 \mathrm{~cm}$ screen) fed with $30 \%$ of a grain-mineral-vitamin mix.

- Assuming grain worth $13 \mathrm{c} / \mathrm{kg}$; lamb gains worth $\$ 2.20 / \mathrm{kg}$; and that feed is $40 \%$ of cost of production.

Because both grinding and supplementing with grain tend to reduce the differences in feeding value of hays, it is likely that there would have been an even greater spread in the relative values of hays had they been fed in the long state as the only feed.

\section{MOISTURE CONTENT AT HARVESTING}

In general terms, the higher the moisture content at harvesting, the less will be the leaf loss in the field but the greater will be the potential for spoilage losses in storage. Baling or mechanically stacking forages when they are too dry is particularly harmful to legume crops such as alfalfa and sweetclover. 
It has been determined that under average conditions, the loss of fine leaf and flower material from the hale chamber of a standard baler is around 2 to $3 \%$. This will be greater as the dry matter content increases past $75-80 \%$. What is more important than the physical loss is the loss in quality. One study showed that the fine material lost, averaged $22 \%$ crude protein, $21 \%$ crude fibre and $67 \%$ TDN while the hay in the bale averaged $14.5 \%$ crude protein, $32 \%$ crude fibre and $59.5 \%$ TDN. Thus the loss in feeding value would be close to $5 \%$ at normal moisture levels.

Where the forage is to be baled and placed directly into storage, moisture levels should be around 20\% for legumes and 25\% for grass hays. If it appears that weather conditions will remain dry, forage can be baled at somewhat higher moisture levels (25\% for alfalfa, 30\% for grass hays) and left in the field either as stooks or round bales to undergo further drying. However, much feeding value is lost because too many forage producers leave square baled hay out in the field too long and spoilage or weathering occurs. If using stacking wagon systems, slightly higher moisture levels than for square baling may be used, particularly, if the stacks are to be deposited in the field rather than being transported some distance, which of course will cause the stack to settle and become more difficult to dry out. Extreme care is required to put a good water-resistant top on stacks, particularly those made with the Mckee units. If using the soft core round baler system, somewhat higher moisture levels than for standard square bales may be employed since the bales will dry out better than the hard core type.

An ideal method for harvesting good quality alfalfa is to field wilt to $35-40 \%$, coarsely chop and artificially dry to $20 \%$ moisture using a loft or shed drying system or a hay drying tower. If proper handling practices are observed, there should be very little loss in the field and in storage.

With silage, moisture content is also very important. Dry matter should be between 35 and $40 \%$ for pit, pile or bunker silos and between 40 and $50 \%$ for oxygen limiting (including plastic bag or tube) silos. Excessive moisture leads to poor quality, leaching losses, bulky silage and increases the possibility of freezing. Too little moisture leads to difficulty in packing, excessive oxidation and the possibility of burnt silage. Speed is of the essence in silage making, if the process is interrupted the material present should be thoroughly packed and temporarily covered with plastic held in place with old tires, straw bales, netting, etc., to minimize oxidation.

In the remainder of this publication various methods of improving the feeding value of forages and of improving the performance of livestock fed high forage rations will be presented.

\section{PORAGE CROPS FOR LIVESTOCK FEED IN THE ASPEN PARKBELT}

Almost any crop grown can be classed as a forage crop if the whole above-ground portion of the plant is either grazed or cut and put up as hay 
or silage. Thus, not only the more commonly used forage crops such as alfalfa, bromegrass, crested wheatgrass, sweetclover, etc., but crops such as oats, faba beans, corn and even canola can be included in the definition of forage crops when the whole plant is used for livestock feed.

As a class, forage crops are much more variable as to feeding value then are seed crops such as cereals, oilseeds and pulse crops. Almost invariably they contain more crude fibre (cellulose, hemi-cellulose and lignin), are lower in digestible energy and contain less phosphorus then do the seed crops, although some forages cut at the right stage of growth will contain as much or more crude protein and be higher in calcium than the seed crops. Most forages will contain at least some carotene or provitamin $A$, while most seed crops will contain essentially none.

Forages such as alfalfa, bromegrass, crested wheatgrass, and oats, can be used for pasture, hay and silage. Some crops such as Russian wild ryegrass, because of their physical form and seeding pattern are used mainly for grazing, although it's not impossible to put them up as hay. Some legumes such as sweetclover, red clover and faba beans are very difficult to put up as hay for a number of reasons including difficulty in field drying, shattering of leaf material when baling, and difficulty in storing in the form of bales left out in the weather. These crops are thus much better suited to putting up as silage. Corn, of course, is put up as silage.

From a practical view point it must be recognized that the choice of forage crops in any particular situation will probably depend on factors other than quality considerations. The ability to establish and yield well on a particular soil or under a particular condition (salinity, flooding, etc.) should, in most situations, be the deciding factor. The cost of working and seeding the land could be another. Once the most productive or least cost forage or forages are identified, then the livestock system, including the harvesting and storing system, should be tailored to that crop. Some examples may be in order to illustrate this.

1. On rocky, hard to work land, perennial forages would have a real advantage over annual forages in terms of the cost of working and seeding the land. In this situation the forage might be far better harvested as pasture than as hay or silage due to the cost of operating equipment over rough land.

2. If cereals produce more nutrients per acre than perennial forages (perhaps because of the need to summerfallow to build up sufficient moisture reserves to produce a good crop) then perhaps a livestock feeding system built around silage would be indicated. The production of some cereal crops in a cropping-livestock system would also facilitate the return of manure to the land and could in most years be used at least in part in conjunction with perennial pastures to assure a uniform supply of feed (pasture or soilage) for the grazing herd.

The role of specific forage crops in a livestock-cropping system in northern Saskatchewan is summarized as follows. 


\begin{abstract}
Alfalfa
Alfalfa is a perennial legume which is often grown as a soil improving crop. It can be harvested when high in protein content and used in the dehy industry. It can also be put up as baled or chopped and artificially dried hay and, if of good quality, can serve as an excellent supplement to lower quality roughages (including cereal straw) when fed to wintering beef cows at around 2-3 kg/head/day, or used as a high quality forage for dairy cows, growing stock and for finishing steers and lambs. Because it can cause bloat under some conditions it should be seeded with grasses, such as bromegrass, crested wheatgrass or intermediate wheatgrass when used for pasture. When harvested as hay and fed in the ground form to finishing cattle no bloat problems have been experienced unless fed with from $30-70 \%$ grain.
\end{abstract}

\title{
Sweetclover
}

Sweetclover is an excellent soil improving crop fitting well into cereal crop rotations. It can be plowed down as a green manure or harvested for feed, preferably as silage, since it is difficult to put up as hay. If coumarin containing varieties become moldy, sweetclover disease can result.

On slight to moderately saline soils, not subject to more than a week of flooding, sweetclover may be sown to improve the feeding value of the grass stand. It is subject to infestation by weevils.

Sweetclover can in some years contribute significantly to the yield of a cereal-sweetclover mixture. When this occurs it may be more profitable to put the whole crop up as silage, than to harvest it for grain.

\section{Sainfoin}

Sainfoin is a very palatable non-bloat producing legume yielding about $10-20 \%$ less than alfalfa. It is somewhat less winter hardy than alfalfa. It is not a good competitor with weeds and other forages. However, it grows well in combination with bunch grasses (RWR and CWG) but not in combination with aggressive, rhizomatous species such as bromegrass.

Because sainfoin retains its leaves longer than alfalfa, it can be harvested at a more advanced stage of maturity without appreciable loss of quality. It should be cut for hay at between $50-100 \%$ bloom stage for optimum yield of nutrients. 


\section{Red clover}

Because of the physical nature of this crop it is very difficult to harvest as good quality hay. Most of the crop in NE Saskatchewan is used for seed production. Red clover is suited to humid regions with moderate to cool temperatures but will not thrive under prolonged periods of drought.

It is recommended that red clover be cut at $10 \%$ bloom for hay production (crimp to speed-drying) and at the mid to full bloom stage (approx. $70 \%$ moisture) for silage production. Some additional field wilting could improve feeding value, provided it did not increase shattering losses.

Where it can be grown, it fits in well with short term rotations (2-3 years) and is a useful component in pasture mixtures.

\section{GRASSES}

The most common grasses produced for hay or silage in northern Saskatchewan are bromegrass, crested wheatgrass, intermediate wheatgrass, tall wheatgrass, and reed canarygrass.

\section{Bromegrass}

Bromegrass produces well under most conditions in the black and gray wooded soils and for both hay and pasture production should be seeded with alfalfa to increase yield and quality. When cut in the early bloom stage it will recover to yield a good second cut in most years. It is quite palatable to beef cattle of all classes and presents few problems in harvesting and storing.

\section{Crested wheatgrass}

Crested wheatgrass is one of the most under-rated crops in the black soil zone. It is normally thought of as being a dryland grass, but at Melfort it has been one of the best producing grasses both as hay and under grazing, particularly in the first half of the growing season. It will go dormant in a dry spell. The crop is easy to establish, a good competitor and one of the easiest to harvest in terms of time required to cure in the field following cutting. Feeding trials also show it is more efficiently used than alfalfa at comparable stages of maturity. It grows well in combination with alfalfa. It has also been found that this hay, when ground and processed into complete cattle growing or finishing rations requires more power than is the case when alfalfa is similarly processed. Crested wheatgrass has slight to moderate tolerance to salinity but will not withstand flooding for more than two weeks. 


\section{Intermediate wheatgrass}

Intermediate wheatgrass is recommended for all areas of Saskatchewan. It is suitable for pasture and hay production, preferably seeded with alfalfa. At Melfort, a mixture of intermediate wheatgrass and alfalfa compared favorably to brome alfalfa but because intermediate wheatgrass was less competitive, its contribution to the yield dropped after 3-4 years.

\section{Tall wheatgrass}

Tall wheatgrass is a somewhat coarser grass than bromegrass but is one of the most saline-tolerant forage crops. It is relatively easy to put up as hay, with good drying time and minimum leaf loss. Feeding trials at Melfort have shown the hay to be quite palatable both in the long and ground forms. Even when relatively mature, feeding value would be quite adequate to meet the nutrient requirement of wintering cows.

\section{Reed canarygrass}

Reed canarygrass is well adapted to wet soils and can stand flooding for up to 5 weeks. Probably because it is grown in wet areas, it is often harvested at a mature state which renders it of lower feeding value. If harvested in the immature stage, the crop is palatable and of good feeding value. At Melfort the crop has been harvested as green crop, baled hay and silage, with yields of over 6 tonnes/ha in the first cut. As the crop matures alkaloid levels can cause palatability problems. The crop tolerates a wide range of soil pH (4.9-8.3) but does not withstand salinity. Low alkaloid varieties are recommended.

\section{Meadow bromegrass}

Meadow bromegrass is adapted to the same areas as bromegrass. The grass can extend the prime grazing season as well as increase total forage production and is very compatible with alfalfa. It yields as much total forage as smooth bromegrass but has much faster recovery and better fall growth. It differs from bromegrass in that it is less strongly creeping, slower to become established and has more basal leaves. Alone or in combination with a legume it makes excellent, palatable hay.

\section{Meadow foxtail}

Meadow foxtail is a long lived perennial grass resembling timothy. It is adapted to the cool, moist conditions found in the gray luvisol soil areas of the Aspen parkland. It is second only to reed canarygrass in its tolerance to flooding. It is alkali tolerant and fairly tolerant to acidity. It is easy to establish and quite competitive. Seed is difficult to harvest and thus expensive. It produces early in the season and has good recovery, 
hence where conditions permit, two cuts can be obtained.

\section{Annual crops}

Annual crops recommended for forage production in the black and gray wooded soils include oats, winter wheat, fall rye, barley, faba beans and corn.

Barley, particularly if sown with field peas, faba beans, or in some years sweetclover, makes an excellent silage. Bonanza or any smooth awned variety is recommended.

0ats of any recommended variety is a relatively good yielder. When grown either alone or with field peas it makes an excellent silage. 0ats may be hayed, but field drying may be difficult, particularly if the stand is heavy.

When growing conditions are suddenly interrupted due to drought or frost, there is a danger that nitrate levels will become toxic, particularly if the crop has been fertilized with nitrogen ( $2 \%$ may be toxic). If toxic levels are found, increase vitamin A levels and dilute the feed with another forage, grain, straw, etc..

Utility wheat (Glenlea) and fall rye (any recommended variety) can be used for hay or silage.

Faba beans of any recommended variety make excellent silage. Color will not be attractive (dark brown to black) but the palatability is excellent. The high protein content makes this an ideal supplement for cows wintered on cereal straw plus a little grain. Intake by growing beef cattle and sheep has been excellent and good rates of gain are achieved.

Corn varieties are now available which will give good yields of dry matter. However, under conditions at Melfort, palatability has not been good perhaps due to low dry matter content. This means that other dry feeds, grain or hay would have to be fed with the silage to support reasonable rate of gain or milk production.

\section{SUMMARY}

In summary there is a wide variety of forage crops available to livestock feeders in the Aspen Parkbelt. Within each crop there is a wide range in quality or feeding value. To permit intelligent use of these feedstuffs by ruminant livestock, it is essential that they be analysed for dry matter and crude protein at least. Where the forages alone, or in combination, fail to meet the requirements of the class of livestock being fed, some supplemental feeding (grain, protein supplement or minerals) or some physical processing will be necessary to increase nutrient intake or 
perhaps a combination of the two will be required if forage crops are to be effectively and economically utilized for livestock production.

For more information on the production of forage crops in the Aspen Parkbelt, please refer to companion publications: "Pasture Production and Utilization in the Aspen Parklands of Western Canada" or "Forage Crop Production in the Aspen Parklands of Western Canada".

\section{HOW MUCH FORAGE WILL VARIOUS CLASSES OF LIVESTOCK CONSUME?}

The maximum amount of forage voluntarily consumed by an animal will depend on the nutritional quality of the forage, on the physical form in which it is fed, on the attractiveness of the feed (freedom from contaminants, spoilage, excessive dust, etc.), and, in the case of silage, on its moisture content or bulkiness. The amount actually fed may be less depending on the productive level desired and on the cost of forages, relative to other feeds. Table 7 provides estimates of the amount of forages of different kinds, qualities and physical forms, that may be consumed by various classes of livestock. Because factors in addition to those listed can affect intake of forages, these figures should be used as a guide only. In an actual feeding situation, amounts of forages fed should be increased or reduced depending on the performance of the livestock involved.

\section{Comments (Table 7)}

1. Silage is especially useful in beef cow rations as part of the diet. Depending on quality, it may be necessary to "dilute" the ration with straw to prevent fattening.

2. Good quality silage ( $>35 \%$ DM) is useful in growing-finishing rations but because of its bulk may need to be limited (partially replaced with grain) to achieve good rates of gain.

3. While silage may be useful as part of ewe and lamb rations, it is normally not consumed in amounts required to meet requirements for lactating ewes or growing-finishing lambs.

4. Suggested maximum amounts of hay and silage are not necessarily recommended levels of feeding. Animal performance and relative costs of grain and hay will be deciding factors as to the levels of forages fed.

5. For ewes nursing lambs (especially two or more), silage is too bulky to provide adequate nutrients even if full fed. Limit the amount of silage and feed good quality legume hay and/or grain.

6. Processing hay for beef cows should be done only if available roughage cannot be eaten in large enough quantities to support performance requried. 


\begin{tabular}{|c|c|c|c|c|c|c|}
\hline 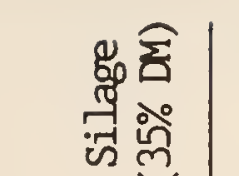 & 焉 & 哥㞿 & $\tilde{y}$ & 8 & $\Xi$ & \\
\hline 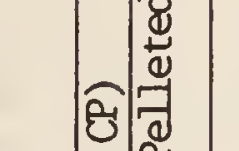 & $\stackrel{\circ}{\circ}$ & $\exists \pm$ & $\Xi$ & $\stackrel{\pi}{2}$ & $\stackrel{\leftrightarrow}{\stackrel{\longrightarrow}{~}}$ & $\vec{i}$ \\
\hline 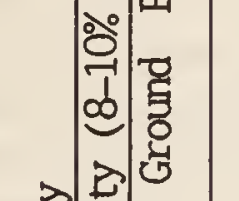 & $\stackrel{8}{i}$ & $\Rightarrow 9$ & $\Xi$ & $\stackrel{\pi}{2}$ & 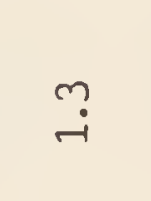 & $\stackrel{9}{I}$ \\
\hline 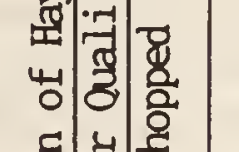 & $\stackrel{\leftrightarrow}{i}$ & $\infty$ & $\stackrel{\pi}{E}$ & $\stackrel{\pi}{\varepsilon}$ & oे & $\underset{-\infty}{-\infty}$ \\
\hline 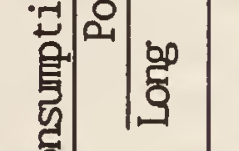 & $\stackrel{\infty}{+}$ & $n^{-\infty}$ & $a$ & $\sigma$ & $\hat{0}$ & $\stackrel{\leftrightarrow}{\longrightarrow}$ \\
\hline 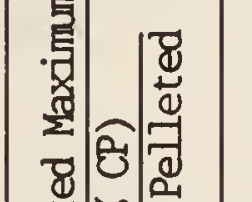 & $\underset{\infty}{\infty}$ & ఇઘ & ๕̊ & $\stackrel{s}{2}$ & 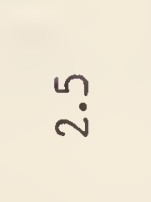 & $\tilde{i}$ \\
\hline 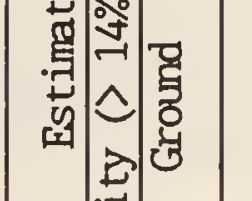 & ळ & $q \neq$ & $\Xi$ & $\cong$ & $\stackrel{\infty}{\rightarrow}$ & $\approx$ \\
\hline 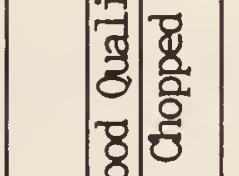 & $\stackrel{\circ}{i}$ & $\because \approx$ & $\Xi$ & $\stackrel{5}{8}$ & $\stackrel{\ddagger}{\ddagger}$ & $\stackrel{i}{i}$ \\
\hline $\mid$ & 2 & $\alpha q$ & \pm & 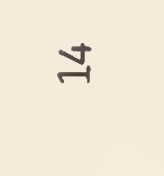 & $\cong$ & $\stackrel{\rho}{=}$ \\
\hline 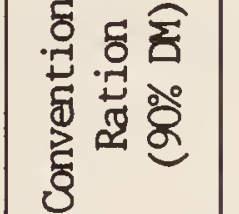 & $\overrightarrow{6}$ & 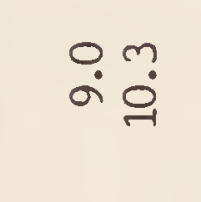 & $\stackrel{\circ}{\circ}$ & $\stackrel{g}{3}$ & $\stackrel{\infty}{\rightarrow+}$ & $\stackrel{\circ}{i}$ \\
\hline & 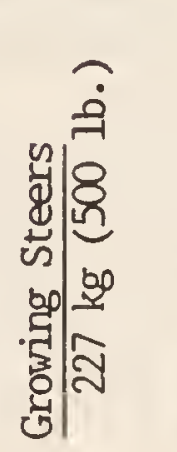 & & & & & \\
\hline
\end{tabular}




\section{THE ROLE OF HARVESTED FORAGES IN MEETING THE NUTRITIONAL REQUIREMENTS OF BEF,F CATTLE. AND SHEEP}

\section{NUTRITIONAL REQUIREMENTS}

The nutritional requirements of ruminant livestock are relatively simple, compared to those of monogastric livestock such as swine and poultry. Normally, the latter are considered to be much more efficient converters of feed to food but this "judgment" is made on the basis of quantitative rather than qualitative considerations. Efficient livestock production is not always indicated by the units of feed required to produce a unit of gain. For example, it is now possible to produce a kilogram of liveweight gain with broiler chicken, on a kilogram or less of feed. However, that feed is expensive and most of it could be consumed directly by humans. Beef cattle are derided because they need 10 to 12 units of hay, silage or pasture dry matter per unit of gain. What is overlooked is that they are converting a product of essentially no nutritional value to humans into a highly nutritious and palatable food, thereby serving to effectively utilize millions of hectares of non-arable land around the world. In addition, they provide a market for surplus or otherwise unsaleable grain and the forage crops produced on large areas of tillable soils to prevent or reverse deterioration due to poor farming practices. They are thus a very vital component of the agricultural system.

The material that follows concentrates on the utilization of forage crops, primarily perennial forage crops, for the production of beef and is directed to the smaller, on-farm beef cattle feeding operations, where the role of the beef enterprise is to market farm-produced forages.

Before considering the role of harvested forages in meeting the nutritional requirements for beef cattle and sheep, we should summarize, for some of the more common classes of livestock, what those requirements are. Because processing forages will markedly increase intake and thus make it possible to consume more nutrients, the requirements are expressed in weight units rather than percentages. Table 8 summarizes the estimated nutritional requirements of beef cattle and sheep.

It must be remembered that figures in Table 8 are estimates and that actual requirements will be affected by the genetic potential of the individual animal, the relative maturity of the breed of animal involved (at the weight given) on weather conditions, the use of growth stimulating implants and additives, the health of the animal and on the degree of stress to which the animal is exposed (temperature extremes, insect pests, handling methods, use of bedding, muddy feedlots, etc.) 
Table 8. Estimated nutritional requirements of cattle and sheept

\begin{tabular}{|c|c|c|c|c|c|c|c|c|}
\hline Class of Animal & $\begin{array}{l}\text { Height } \\
(\mathrm{kg})\end{array}$ & $\begin{array}{l}\text { Gain } \\
\text { per } \\
\text { day } \\
(\mathrm{kg})\end{array}$ & $\begin{array}{l}\text { Minimal } \\
\text { dry } \\
\text { matter } \\
(\mathrm{kg})\end{array}$ & $\begin{array}{l}\text { Crude } \\
\text { protein } \\
\text { (kg) }\end{array}$ & $\begin{array}{c}\text { Digestible } \\
\text { nutrients } \\
\text { (kg) }\end{array}$ & $\begin{array}{l}\text { Calcium } \\
\text { (g) }\end{array}$ & $\begin{array}{l}\text { Phosphorus } \\
\text { (g) }\end{array}$ & $\begin{array}{c}\text { Vitamin A } \\
\text { I.U. } \\
\left({ }^{\prime} \infty 0^{\prime} s\right)\end{array}$ \\
\hline Growing-finishing steers & $\begin{array}{l}250 \\
350 \\
450 \\
550\end{array}$ & $\begin{array}{l}1.1 \\
1.3 \\
1.4 \\
1.4\end{array}$ & $\begin{array}{r}6.0 \\
8.0 \\
8.3 \\
10.0\end{array}$ & $\begin{array}{r}0.75 \\
0.9 \\
1.0 \\
1.0\end{array}$ & $\begin{array}{l}4.8 \\
7.0 \\
8.5 \\
9.5\end{array}$ & $\begin{array}{l}26 \\
26 \\
25 \\
25\end{array}$ & $\begin{array}{l}21 \\
22 \\
23 \\
23\end{array}$ & $\begin{array}{l}14 \\
18 \\
18 \\
20\end{array}$ \\
\hline Growing-finishing heifers & $\begin{array}{l}200 \\
300 \\
400 \\
500\end{array}$ & $\begin{array}{l}0.9 \\
1.1 \\
1.1 \\
1.1\end{array}$ & $\begin{array}{l}5.5 \\
7.5 \\
8.5 \\
9.5\end{array}$ & $\begin{array}{l}0.65 \\
0.80 \\
0.80 \\
0.80\end{array}$ & $\begin{array}{l}4.5 \\
6.0 \\
7.2 \\
8.0\end{array}$ & $\begin{array}{l}26 \\
22 \\
19 \\
17\end{array}$ & $\begin{array}{l}23 \\
22 \\
18 \\
16\end{array}$ & $\begin{array}{l}19 \\
23 \\
19 \\
19\end{array}$ \\
\hline Wintering pregnant cow & $\begin{array}{l}450 \\
550 \\
650\end{array}$ & $\begin{array}{l}- \\
- \\
-\end{array}$ & $\begin{array}{l}7.0 \\
8.0 \\
9.0\end{array}$ & $\begin{array}{r}0.4 \\
0.45 \\
0.5\end{array}$ & $\begin{array}{l}3.6 \\
4.2 \\
4.7\end{array}$ & $\begin{array}{l}12 \\
14 \\
16\end{array}$ & $\begin{array}{l}12 \\
14 \\
16\end{array}$ & $\begin{array}{l}19 \\
22 \\
25\end{array}$ \\
\hline Nursing cow & $\begin{array}{l}450 \\
550 \\
650\end{array}$ & $\begin{array}{l}- \\
- \\
-\end{array}$ & $\begin{array}{l}10.0 \\
10.5 \\
11.5\end{array}$ & $\begin{array}{l}0.9 \\
1.0 \\
1.1\end{array}$ & $\begin{array}{l}5.0 \\
5.6 \\
6.2\end{array}$ & $\begin{array}{l}26 \\
28 \\
29\end{array}$ & $\begin{array}{l}26 \\
28 \\
29\end{array}$ & $\begin{array}{l}23 \\
26 \\
29\end{array}$ \\
\hline Growing replacement lamb & $\begin{array}{r}60 \\
80 \\
100\end{array}$ & $\begin{array}{l}0.44 \\
0.33 \\
0.22\end{array}$ & $\begin{array}{l}2.3 \\
2.8 \\
2.8\end{array}$ & $\begin{array}{l}0.48 \\
0.55 \\
0.55\end{array}$ & $\begin{array}{l}1.4 \\
1.6 \\
1.6\end{array}$ & $\begin{array}{l}7.2 \\
7.9 \\
8.3\end{array}$ & $\begin{array}{l}4.0 \\
4.4 \\
4.6\end{array}$ & $\begin{array}{l}2.5 \\
3.4 \\
4.3\end{array}$ \\
\hline Finishing lamb & $\begin{array}{l}30 \\
40 \\
50\end{array}$ & $\begin{array}{l}0.44 \\
0.55 \\
0.48\end{array}$ & $\begin{array}{l}1.3 \\
1.6 \\
1.8\end{array}$ & $\begin{array}{l}0.31 \\
0.39 \\
0.44\end{array}$ & $\begin{array}{l}0.83 \\
1.12 \\
1.26\end{array}$ & $\begin{array}{l}4.8 \\
5.0 \\
5.0\end{array}$ & $\begin{array}{l}3.0 \\
3.1 \\
3.1\end{array}$ & $\begin{array}{l}0.76 \\
1.02 \\
1.27\end{array}$ \\
\hline$\frac{\text { Pregnant dry ewe (last } 6}{\text { weeks gestation) }}$ & $\begin{array}{l}60 \\
70 \\
80\end{array}$ & $\begin{array}{l}0.40 \\
0.41 \\
0.42\end{array}$ & $\begin{array}{l}1.9 \\
2.1 \\
2.2\end{array}$ & $\begin{array}{l}0.39 \\
0.43 \\
0.45\end{array}$ & $\begin{array}{l}1.1 \\
1.2 \\
1.3\end{array}$ & $\begin{array}{l}4.4 \\
4.5 \\
4.8\end{array}$ & $\begin{array}{l}4.1 \\
4.3 \\
4.5\end{array}$ & $\begin{array}{l}5.1 \\
6.0 \\
6.8\end{array}$ \\
\hline$\frac{\text { Nursing ewe (last } 8 \text { weeks }}{\text { suckling twins) }}$ & $\begin{array}{l}60 \\
70 \\
80\end{array}$ & $\begin{array}{l}- \\
- \\
-\end{array}$ & $\begin{array}{l}2.3 \\
2.5 \\
2.6\end{array}$ & $\begin{array}{l}0.53 \\
0.57 \\
0.59\end{array}$ & $\begin{array}{l}1.5 \\
1.6 \\
1.7\end{array}$ & $\begin{array}{l}11.5 \\
12.0 \\
12.6\end{array}$ & $\begin{array}{l}8.2 \\
8.6 \\
9.0\end{array}$ & $\begin{array}{l}5.1 \\
6.0 \\
6.8\end{array}$ \\
\hline Beef bull - growing & $\begin{array}{l}300 \\
500\end{array}$ & $\begin{array}{l}1.0 \\
0.7\end{array}$ & $\begin{array}{r}9 \\
13\end{array}$ & $\begin{array}{l}0.9 \\
1.1\end{array}$ & $\begin{array}{l}5.6 \\
7.5\end{array}$ & $\begin{array}{l}27 \\
22\end{array}$ & $\begin{array}{l}23 \\
22\end{array}$ & $\begin{array}{l}34 \\
48\end{array}$ \\
\hline Beef bull - mature & $\begin{array}{r}800 \\
1000\end{array}$ & $\begin{array}{l}0.0 \\
0.0\end{array}$ & $\begin{array}{l}11 \\
13\end{array}$ & $\begin{array}{l}0.9 \\
1.1\end{array}$ & $\begin{array}{l}5.8 \\
6.9\end{array}$ & $\begin{array}{l}19 \\
22\end{array}$ & $\begin{array}{l}19 \\
22\end{array}$ & $\begin{array}{l}40 \\
48\end{array}$ \\
\hline
\end{tabular}

*Adapted from NRC Recommendations (some rounding and extrapolation).

\section{EFFECT OF FORAGE QUALITY ON THE EXTENT TO WHICH HAY AND SILAGE CAN MEET NUTRIENT REQUIREMENTS OF BEEF CATTLE}

The degree to which harvested forages (hay and silage) can meet the requirements of livestock will depend on the amount of forage which the animals will consume, and this will depend on the quality (nutrient content, palatability) and bulkiness of the forage. Bulkiness of hays can be reduced by physical processing. The following three Tables 9, 10, and 11, indicate the amount of various quality forages ("as-fed" basis) needed to meet the TDN 
requirements of a beef cow, growing steer and finishing steer, respectively.

Table 9. Meeting nutrient requirements of a $500 \mathrm{~kg}$ pregnant beef cow with forages

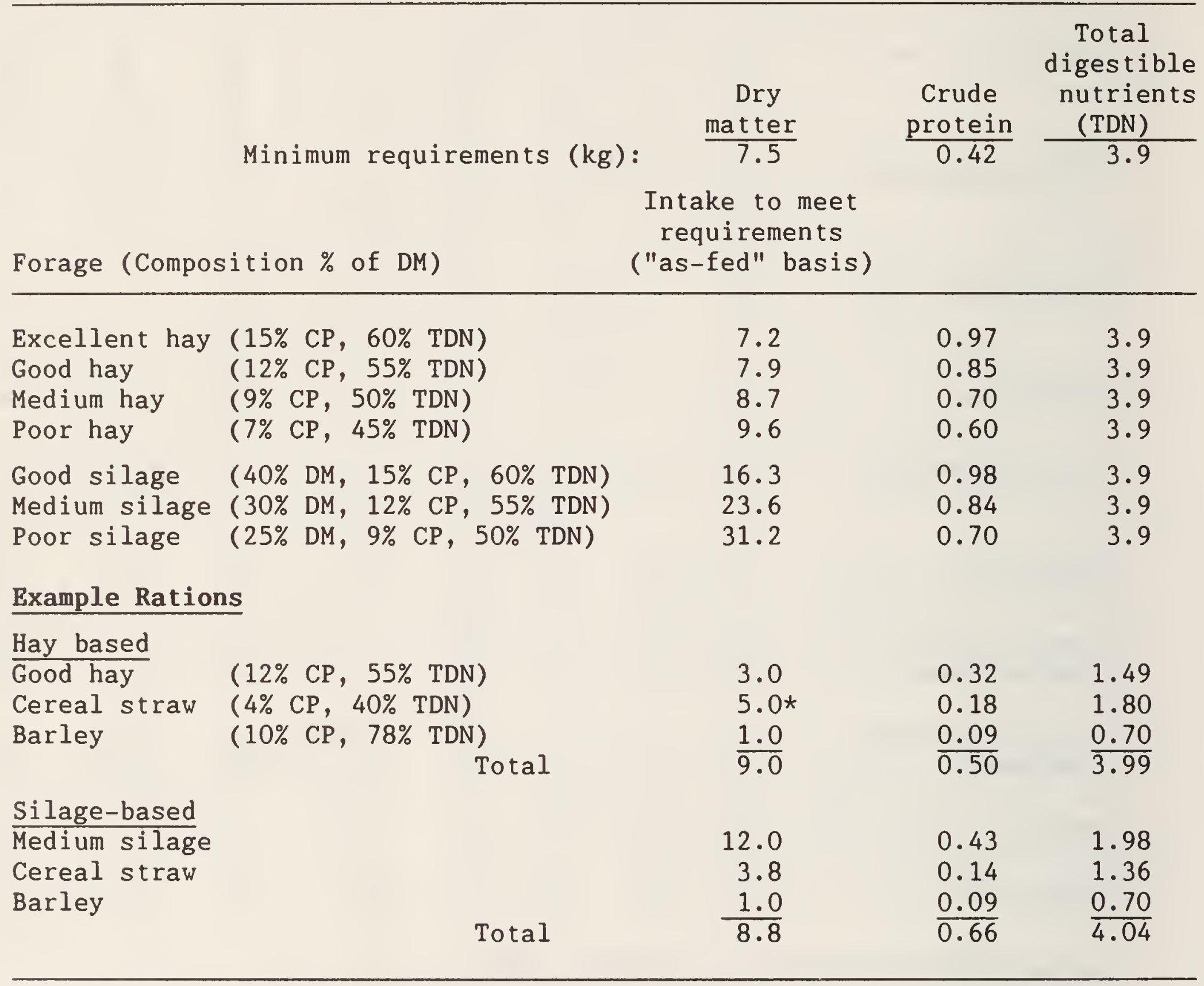

*Probably the maximum voluntary intake of straw of average quality.

Comments (Table 9)

1. If fed any of the hays free choice, cows would consume more than they needed to meet nutritional requirements, would become too fat and would be too costly to feed. Limiting consumption to the amount required to meet nutrient needs would lead to under-satisfied appetites. Similarly, cows could consume enough of all but the poor quality silage to meet their nutritional requirements. Thus it will make good economic sense in the Aspen 
Parkland, where straw is plentiful and cheap, to allow cattle to consume straw, free choice, and to limit-feed hay or silage (and perhaps a little grain - depending on the condition of the cows) as required to keep cows in good (not too fat, not too thin) condition during the winter. Use the best quality straw available and be sure to feed more hay, silage and/or grain in extremely cold weather, otherwise cows will tend to overeat straw and their rumens may become impacted. Providing de-chilled water, on a free-choice basis, is also essential for cows consuming straw free choice.

2. It is assumed that cobalt-iodized, trace mineralized salt, a calcium phosphate supplement and vitamin A will be provided to meet requirements.

3. Only in extreme cases (highly unpalatable, coarse hays) would chopping or grinding roughage for cows be justified.

Table 10. Meeting nutrient requirements of a $250 \mathrm{~kg}$ growing beef steer gaining $1.1 \mathrm{~kg} /$ day

$$
\begin{aligned}
& \text { Dry Crude digestible } \\
& \text { Minimum requirements }(\mathrm{kg}): \frac{\text { matter }}{6.0} \quad \frac{\text { protein }}{0.75} \quad \frac{\text { nutrient }}{4.8}
\end{aligned}
$$

Intake to meet requirements $(\mathrm{kg})$

Forage (Composition \% of DM) ("as-fed" basis)

$\begin{array}{llrrr}\text { Excellent hay } & \text { (15\% CP, 60\% TDN) } & 8.9 & 1.20 & 4.8 \\ \text { Good hay } & (12 \% \mathrm{CP}, 55 \% \mathrm{TDN}) & 9.7 & 1.04 & 4.8 \\ \text { Medium hay } & \text { (9\% CP, 50\% TDN) } & 10.7 & 0.87 & 4.8 \\ \text { Poor hay } & (7 \% \mathrm{CP}, 45 \% \mathrm{TDN}) & 11.9 & 0.75 & 4.8 \\ \text { Good silage }(40 \% \mathrm{DM}, 15 \% \mathrm{CP}, 60 \% \mathrm{TDN}) & 20 & 1.20 & 4.8 \\ \text { Medium silage } & (30 \% \mathrm{DM}, 12 \% \mathrm{CP}, 55 \% \mathrm{TDN}) & 29 & 1.04 & 4.8 \\ \text { Poor silage } & \text { (25\% DM, 9\% CP, 50\% TDN) } & 38 & 0.86 & 4.8\end{array}$

\section{Example of Balanced Rations}

Hay based (ground, complete)

Good hay

Straw

Rolled barley

Silage- based

Good silage

Dry rolled barley

$\begin{array}{clll} & 5.0 & 0.54 & 2.48 \\ & 1.0 & 0.036 & 0.36 \\ \text { Total } & \frac{3.0}{9.0} & \frac{0.27}{0.84} & \frac{2.11}{4.95}\end{array}$

( $90 \%$ DM basis)

$\begin{array}{rrr}12.5 & 0.45 & 2.06 \\ 4.0 & \frac{0.36}{0.81} & \frac{2.81}{4.87}\end{array}$

Total

(90\% DM basis) 


\section{Comments (Table 10)}

1. Steer calves of this weight might consume $8.9 \mathrm{~kg}$ of $90 \%$ DM excellent quality hay in the long form, but could not consume the required amounts of the good hay unless it was ground through a $1.27 \mathrm{~cm}$ screen. They could not consume enough of the medium or poor quality hays, even if ground, to meet their requirement for a $1.1 \mathrm{~kg}$ daily gain and would thus need a high energy supplement such as grain or acidulated fatty acids.

2. It is, for practical purposes, sufficient to use average composition figures for determining the extent to which these rations meet the calcium and phosphorus needs of the animals involved. However, all animals must have access to cobalt-iodized salt and a mineral mixture made up of trace mineralized salt and a calcium phosphorus supplement. Where minimal grain is being fed daily, a high phosphorus supplement (eg. $18 \% \mathrm{Ca}, 20.5 \% \mathrm{P}$ ) should be used, as forages are low in phosphorus.

3. If available feedstuffs contain inadequate protein to meet the requirements of the animals being fed (determined by a laboratory analyses of the feed) additional protein will be required. Canola meal, a commercial protein supplement, heavy (high quality) pulse crop (pea, bean, lentil) screenings, legume seed (sweetclover, alfalfa) screenings, or high protein $(15-16 \% \mathrm{CP}$ ) wheat, if available at reasonable prices (compare the cost of a unit of protein), can be added to the ration to bring up the crude protein level. Screenings should be finely ground to improve digestibility and reduce the number of viable weed seeds in the manure.

4. While example rations are shown in terms of kilograms per head per day, it is essentially impossible to predict what the actual daily intake will be under self-feeding conditions. The livestock producer must monitor his cattle closely (and preferably have the facilities to weigh all or representative cattle at at least two week intervals) to determine whether they are growing or finishing at an optimal rate. If, for example, growing steers self-fed a complete ground ration, are gaining too slowly it will, in the example cited, be necessary to reduce the straw and increase the hay or grain. If they are growing too rapidly and tending to finish at too light a weight, then the straw or hay content of the ration will have to be increased at the expense of the grain.

In the case of the silage ration, it is likely that both the silage and the grain would be "hand"-fed once or twice daily, either alone or mixed together (mixer wagon). In this situation it is easy to make adjustments in the proportions of the two major ingredients on a day to day basis.

5. Don't forget to provide vitamin A to all cattle at recommended levels, either by mixing it in the feed or by injection. Grain and cereal straw contain essentially no vitamin $A$ and weathered hay will likely contain very little. 
6. Note that when forages of medium to excellent quality are fed as the major component of the ration, that, at levels to meet energy (TDN)

requirements, the crude protein requirement is exceeded by a considerable amount. To some extent this may be regarded as a waste of protein, however, high protein levels of forages are directly related to digestible energy content. Normally this extra protein is relatively low cost, and is converted into energy in the rumen.

Table 11. Meeting nutrient requirements of a $450 \mathrm{~kg}$ finishing steer with forages [daily gain $1.4 \mathrm{~kg}$ ( $3.1 \mathrm{lb}$.$) ]$

\begin{tabular}{|c|c|c|c|}
\hline $\begin{array}{l}\text { Minimum requirements (kg): } \\
\text { rage (Composition \% of DM) }\end{array}$ & $\begin{array}{l}\text { Dry } \\
\text { matter } \\
\frac{8.3}{\text { Intake to meet }} \\
\text { requirements }(\mathrm{kg}) \\
\text { ("as-fed" basis) }\end{array}$ & $\begin{array}{l}\begin{array}{c}\text { Crude } \\
\text { protein }\end{array} \\
1.0\end{array}$ & $\begin{array}{l}\text { Total } \\
\text { digestible } \\
\text { nutrient } \\
8.5\end{array}$ \\
\hline $\begin{array}{ll}\text { Excellent hay } & (15 \% \mathrm{CP}, 60 \% \text { TDN }) \\
\text { Good hay } & (12 \% \mathrm{CP}, 55 \% \mathrm{TDN}) \\
\text { Medium hay } & (9 \% \mathrm{CP}, 50 \% \mathrm{TDN}) \\
\text { Poor hay } & (7 \% \mathrm{CP}, 45 \% \mathrm{TDN})\end{array}$ & $\begin{array}{l}15.7 \\
17.2 \\
18.9 \\
21.0\end{array}$ & $\begin{array}{l}2.1 \\
1.9 \\
1.5 \\
1.3\end{array}$ & $\begin{array}{l}8.5 \\
8.5 \\
8.5 \\
8.5\end{array}$ \\
\hline $\begin{array}{ll}\text { Good silage } & (40 \% \mathrm{DM}, 15 \% \mathrm{CP}, 60 \% \mathrm{TDN}) \\
\text { Medium silage } & (30 \% \mathrm{DM}, 12 \% \mathrm{CP}, 55 \% \mathrm{TDN}) \\
\text { Poor silage } & (25 \% \mathrm{DM}, 9 \% \mathrm{CP}, 50 \% \mathrm{TDN})\end{array}$ & $\begin{array}{l}35.4 \\
51.5 \\
68.0\end{array}$ & $\begin{array}{r}2.1 \\
1.85 \\
1.5\end{array}$ & $\begin{array}{l}8.5 \\
8.5 \\
8.5\end{array}$ \\
\hline Example Rations* & & & \\
\hline $\begin{array}{l}\text { Hay based (ground, complete) } \\
\text { Ground good quality hay } \\
\text { AFA or Tallow ( } 180 \% \text { TDN) } \\
\text { Dry rolled barley ( } 10 \% \mathrm{CP}, 78 \% \text { TDN) } \\
\text { Total }\end{array}$ & $\begin{array}{r}9.5 \\
0.5 \\
4.0 \\
14.0\end{array}$ & $\begin{array}{l}1.0 \\
- \\
\frac{0.4}{1.4}\end{array}$ & $\begin{array}{l}4.7 \\
0.9 \\
2.8 \\
8.4\end{array}$ \\
\hline $\begin{array}{l}\text { Ground, medium quality hay } \\
\text { Dry rolled wheat }(16 \% \mathrm{CP}, 80 \% \text { TDN }) \\
\text { Total }\end{array}$ & $\frac{6}{14}$ & $\begin{array}{l}0.5 \\
\frac{1.1}{1.6}\end{array}$ & $\begin{array}{l}2.7 \\
5.8 \\
8.5\end{array}$ \\
\hline $\begin{array}{l}\text { Silage-based } \\
\text { Medium quality silage } \\
\text { Dry rolled barley }\end{array}$ & $\begin{array}{r}18 \\
\frac{8}{26}\end{array}$ & $\begin{array}{l}0.7 \\
0.7 \\
1.4\end{array}$ & $\begin{array}{l}3.0 \\
\frac{5.6}{8.6}\end{array}$ \\
\hline
\end{tabular}

*Balanced for $\mathrm{CP}$ and TDN only, minerals and vitamin A requirements would have to be considered. 


\section{Comments (Table 11)}

1. In practice, steers of this weight could not consume enough of even the excellent quality hay to meet nutritional requirements, unless it were ground through a $1.27 \mathrm{~cm}$ screen.

2. Because actual intakes are impossible to predict, given the variations in cattle and forages, the livestock producer will need to monitor performance closely and adjust rations accordingly.

3. In practice, if the farmer wants to maximize marketing forages through his beef cattle enterprise, it is best to start cattle out on ground, high quality hay, full-fed from the beginning, and to gradually increase the grain component of the ration, as required, to achieve the rate of finishing desired. Relative price of grain and hay, the animal's ability to gain and finish on a high forage ration, and the trend in market prices will all influence the timing and extent of replacing hay with grain. In general, it will be advantageous to feed a relatively high grain ration during the final few weeks (3-7) in order to increase dressing percentages and, in the case of large-framed, lean cattle, to put on the required amount of fat cover to meet the requirement for top grade. However, it isn't essential if forage-fed cattle are gaining well and putting on the desired amount of finish.

4. The feeder is cautioned against increasing the grain level of cattle being fed ground, high quality hay, particularly alfalfa, as the risk of bloat is increased once the grain level exceeds $30 \%$ and is especially critical at the $50 \%$ level. Risk of bloat is reduced, and indeed better overall performance is achieved, when the quality of the hay is reduced as the level of hay in the ration is reduced (see report elsewhere in this publication).

5. The reader is referred to details of feeding trials with finishing steers elsewhere in this publication for specific details on finishing ration formulae and the performance of cattle fed these rations.

\section{EFFECT OF LEVEL OF HAY CONSUMPTION ON GAINS OF BEEF CALVES}

One of the first experiments carried out at the Melfort station was to determine what kind of performance could be expected when calves were allowed free access to a wide variety of hays (and one silage). Calves were individually fed in separate stalls and had access between feedings to salt, a mineral mix and water. Fourteen different forages were fed (crude protein range 4.3 to $16.7 \%$, digestibile dry matter range 45.1 to $70.1 \%$ ). In subsequent experiments, six other long hays were fed free choice. The information on them (corrected for body weight differences) is included in Fig. 4, which shows the relationship between dry matter (DM) intake and average daily gains of $220 \mathrm{~kg}$ calves fed 20 different forages. 


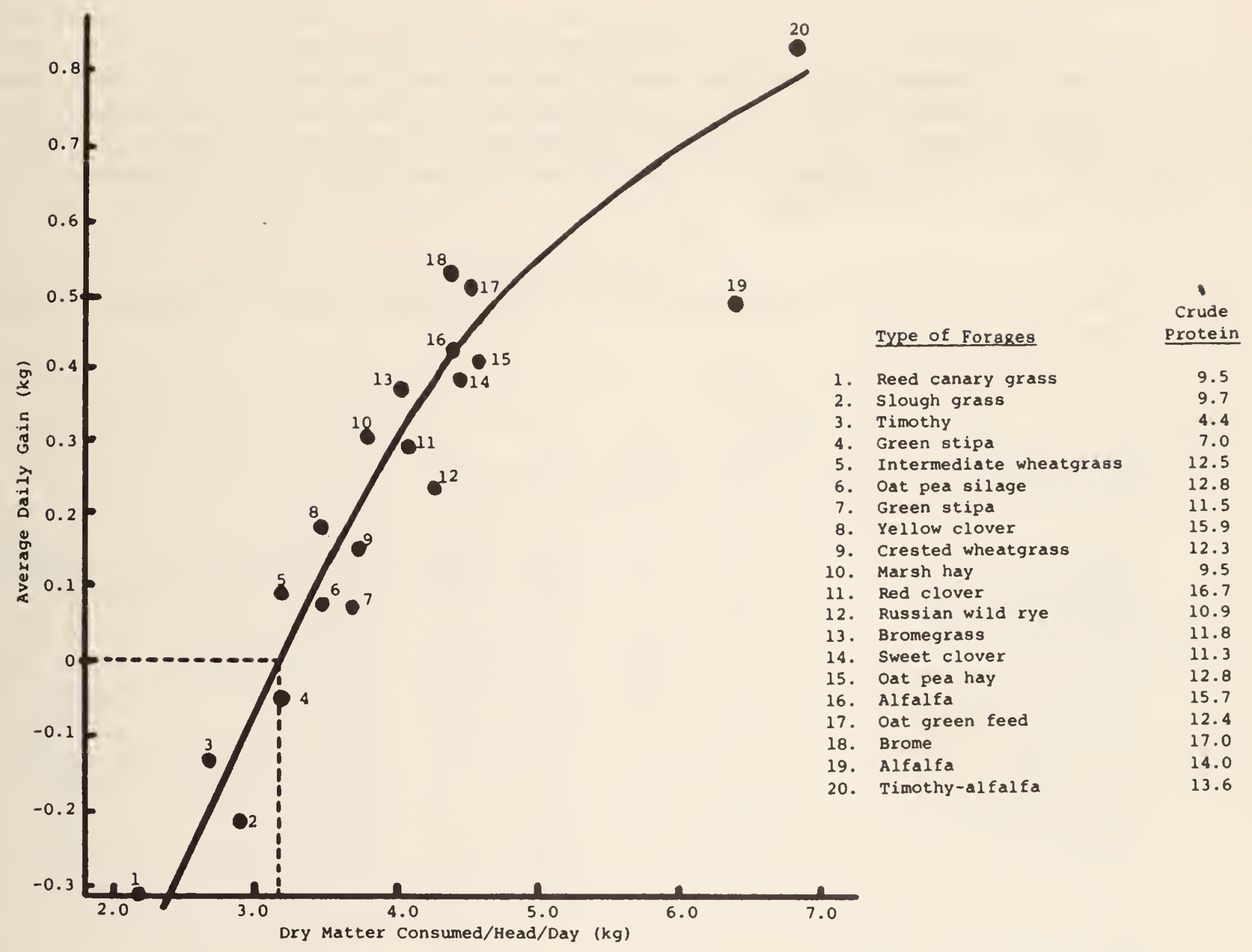

Fig. 4. Relationship between dry matter consumption and rate of gain of $220 \mathrm{~kg}$ beef calves.

These experiments showed a very good relationship between rate of gain and DM intake but also that other factors (crude protein and digestible organic matter) were involved. Maximum intake of about $7 \mathrm{~kg}$ of DM produced a gain of about $0.8 \mathrm{~kg}$ per day, with most of the hays fed consumed at 3 to 4.5 $\mathrm{kg}$ DM per day with gains in the 0.2 to $0.4 \mathrm{~kg} / \mathrm{head} /$ day range. About $3.2 \mathrm{~kg}$ of DM, daily, was required to maintain body weight. There was not a good relationship between rate of gain and crude protein level. The same forages fed as hay or silage produced markedly different rates of gain. It was concluded that if good rates of gain were to be obtained from forage-fed cattle, that methods of increasing intake would have to be developed. 


\section{PROCESSING HAY FOR GROWING BEEF STEERS}

If increasing the density of hay by grinding resulted in the animal consuming more feed before rumen capacity limited intake, it would mean that a smaller proportion of the feed consumed would be required for maintenance, leaving a larger proportion available for production. To determine the effect on density, eleven hays were ground through two or more of six screens, varying from 51 to $3 \mathrm{~mm}$ diameter openings, using a hammermill in a farm type grinder-mixer. The effect on density is shown in Table 12.

Table 12. Effegt of grinding on the density of hays of various species and qualities $\left(\mathrm{kg} / \mathrm{m}^{2}\right)$

\begin{tabular}{|c|c|c|c|c|c|c|c|c|}
\hline \multirow[b]{2}{*}{ Hay type } & \multirow{2}{*}{$\begin{array}{c}\text { Crude } \\
\text { protein } \\
(\%)\end{array}$} & \multirow[b]{2}{*}{$\begin{array}{l}\text { DOM* } \\
(\%)\end{array}$} & \multicolumn{6}{|c|}{ Size of Screen $(\mathrm{mm})$} \\
\hline & & & $\begin{array}{c}51 \\
\left(2^{\prime \prime}\right)\end{array}$ & $\begin{array}{c}25 \\
(1 ")\end{array}$ & $\begin{array}{c}13 \\
(1 / 2 ")\end{array}$ & $\begin{array}{c}6 \\
\left(1 / 4^{\prime \prime}\right)\end{array}$ & $\begin{array}{c}5 \\
\left(3 / 16^{\prime \prime}\right)\end{array}$ & $\begin{array}{c}3 \\
\left(1 / 8^{\prime \prime}\right)\end{array}$ \\
\hline Alfalfa & 16.8 & 60 & 153 & 155 & 185 & 210 & - & 228 \\
\hline Brome-alfalfa & 14.0 & - & 156 & 178 & 215 & - & 274 & - \\
\hline Timothy-alfalfa & 13.8 & - & 143 & - & 199 & - & - & - \\
\hline Brome-alfalfa & 13.1 & 54 & 98 & 97 & 118 & 151 & - & 185 \\
\hline Crested wheatgrass & 12.3 & 53 & 86 & 95 & 115 & 128 & - & 170 \\
\hline Crested wheatgrass & 12.0 & - & 109 & 127 & 153 & - & 188 & - \\
\hline Sweetclover & 11.3 & - & 122 & - & 168 & - & - & - \\
\hline Reed canarygrass & 11.0 & - & 91 & 107 & 125 & - & 166 & - \\
\hline Reed canarygrass & 9.9 & 46 & 53 & 77 & 104 & 131 & - & 174 \\
\hline Slough hay & 9.5 & - & 90 & - & 115 & - & - & - \\
\hline Tall wheatgrass & 6.8 & 41 & 60 & 67 & 84 & 96 & - & 103 \\
\hline
\end{tabular}

*DOM - Digestible Organic Matter

\begin{tabular}{lcc} 
& Whole & Ground \\
\cline { 2 - 3 } Wheat & 749 & 671 \\
Barley & 599 & 437 \\
Oats & 399 & 281
\end{tabular}

Unlike grain, which when ground, decreases in density, grinding hay through progressively smaller screen openings markedly increases density.

In general, as fineness of grinding increases, the density of hay increases. On average, grinding through a $13 \mathrm{~mm}$ (1/2") screen increased density by $23 \%$ compared to processing through a $25 \mathrm{~mm}$ ( 1 ") screen; with the greatest increase (35\%) occurring with the lower quality reed canarygrass.

The relationship of density to crude protein content is not consistent. Density tends to decrease with decreasing protein content, but some species, crested wheatgrass and sweetclover, tended to be denser than would be 
indicated by their protein level. There is a better correlation between density and digestible organic matter for the five forages for which DOM figures were obtained.

Having shown that density of hays was increased by grinding, the next step was to determine how growing beef steers responded to being fed processe hays. The results are of three trials are summarized in Tables 13, 14 and 15 .

Table 13. Effect of physical processing of two hays at different quality on performance of growing steer calves ( 8 wh. feeding period)

\begin{tabular}{|c|c|c|c|c|}
\hline & & Ground & Pelleted & Chopped \\
\hline Long & $\begin{array}{l}\text { Chopped } \\
(2.5-5.0 \mathrm{~cm})\end{array}$ & $\begin{array}{l}\text { (0.5 cm } \\
\text { screen) }\end{array}$ & $\begin{array}{c}(1.1 \mathrm{~cm} \\
\text { diameter) }\end{array}$ & $\begin{array}{l}\text { alfalfa } \\
\text { check* }\end{array}$ \\
\hline
\end{tabular}

$\underline{\text { Green stipa grass (193 kg herefords) }}$

( $7 \%$ crude protein)

$\begin{array}{lrrrrr}\text { Av. daily gain (kg) } & -0.05 & 0.07 & 0.45 & 0.63 & 0.35 \\ \text { Av. daily dry matter } & 3.0 & 3.2 & 4.8 & 5.2 & 4.0 \\ \quad \text { eaten (kg) } & & & & & \\ \text { Feed DM:gain } & \text { neg. } & 44.5 & 10.6 & 8.3 & 11.7 \\ \text { Dry matter digested (\%) } & 53 & 55 & 51 & 50 & 57 \\ \text { Av. daily DDM** eaten (kg) } & 1.6 & 1.7 & 2.5 & 2.6 & 2.3\end{array}$

Bromegrass (218 kg Angus $x$ Herefords) (17.6\% crude protein)

\begin{tabular}{|c|c|c|c|c|c|}
\hline Av. daily gain $(\mathrm{kg})$ & 0.55 & 0.76 & 0.79 & 0.97 & 0.60 \\
\hline $\begin{array}{l}\text { Average daily dry matter } \\
\text { eaten }(\mathrm{kg})\end{array}$ & 4.6 & 5.1 & 5.3 & 5.5 & 5.0 \\
\hline Feed DM:gain & 8.4 & 6.8 & 6.8 & 5.7 & 8.8 \\
\hline Dry matter digested $(\%)$ & 68 & 68 & 65 & 64 & 54 \\
\hline Av. daily DDM eaten (kg) & 3.1 & 3.5 & 3.5 & 3.5 & 2.7 \\
\hline
\end{tabular}

*Fed to calves of both types.

$\star \star$ Digestible dry matter.

Comments (Table 13)

1. Intake and rate of gain was considerably increased by reducing the ration bulk by processing.

2. Processing a poorer quality hay had a much more beneficial effect than processing a high quality hay, converting it from an unproductive feed 
to one that would support a higher rate of gain than the unprocessed good quality hay.

3. Grinding finer than through a $50 \mathrm{~mm}$ screen reduced the digestibility of the forage (the more rapid passage of the feed through the digestive system, probably resulted in incomplete absorption of the digested feed before it was excreted).

Table 14. Effect of reducing particle size on the feeding value of good and fair quality alfalfa hays

\begin{tabular}{|c|c|c|c|c|c|c|}
\hline & \multirow[b]{2}{*}{ Long } & \multirow[b]{2}{*}{ Chopped } & \multicolumn{4}{|c|}{ Ground (screen size, $\mathrm{mm}$ ) } \\
\hline & & & 51 & 25 & 13 & 5 \\
\hline \multicolumn{7}{|l|}{ Good Alfalfa Hay ( $14 \%$ CP) } \\
\hline Average initial weight $(\mathrm{kg})$ & 255 & 253 & 253 & 252 & 251 & 251 \\
\hline Average daily gain $(\mathrm{kg})$ & 0.50 & 0.52 & 0.68 & 0.71 & 0.71 & 0.79 \\
\hline Average daily DM eaten $(\mathrm{kg})$ & 7.9 & 7.9 & 8.5 & 8.5 & 8.4 & 9.4 \\
\hline DM/unit liveweight gain & 16.2 & 15.1 & 12.5 & 11.9 & 11.8 & 12.0 \\
\hline Liveweight gain/tonne DM ( $\mathrm{kg})$ & 61.7 & 66.2 & 80.0 & 84.0 & 84.7 & 83.3 \\
\hline $\begin{array}{l}\text { Relative value of hays* } \\
\text { (\$/tonne) }\end{array}$ & 86.90 & 96.80 & 127.16 & 135.96 & 137.50 & 134.42 \\
\hline $\begin{array}{l}\text { Extra value/tonne due to } \\
\text { quality (long hay) or } \\
\text { processing }(\$)\end{array}$ & 42.90 & 52.80 & 83.16 & 91.96 & 93.50 & 90.42 \\
\hline \multicolumn{7}{|l|}{ Fair Alfalfa Hay $(11.9 \% \mathrm{CP})$} \\
\hline Average initial weight $(\mathrm{kg})$ & 254 & 253 & 253 & 252 & 252 & 253 \\
\hline Average daily gain (kg) & 0.29 & 0.30 & 0.45 & 0.50 & 0.62 & 0.56 \\
\hline Average daily DM eaten (kg) & 6.8 & 6.5 & 7.9 & 8.1 & 8.8 & 8.8 \\
\hline DM/unit liveweight gain & 23.7 & 21.5 & 17.5 & 16.0 & 14.2 & 15.6 \\
\hline Liveweight gain/tonne DM ( $\mathrm{kg}$ ) & 42.2 & 46.5 & 57.1 & 62.5 & 70.4 & 64.1 \\
\hline $\begin{array}{l}\text { Relative value of hays* } \\
\text { (\$/tonne) }\end{array}$ & 44.0 & 53.46 & 76.78 & 88.66 & 106.04 & 92.18 \\
\hline $\begin{array}{l}\text { Extra value/tonne due to } \\
\text { processing }\end{array}$ & CHECK & 9.46 & 32.78 & 44.66 & 62.04 & 48.18 \\
\hline
\end{tabular}

*Based on "fair" quality alfalfa @ \$44/tonne and liveweight gains @ $\$ 2.20 / \mathrm{kg}$.

\section{Comments (Table 14)}

1. Processing through the $13 \mathrm{~mm}$ screen gave optional results for both qualities of alfalfa.

2. Valuing the fair quality hay at $\$ 44 /$ tonne and crediting the 
processed hays with the value of the extra liveweight produced per tonne of hay, indicated some startling increases, in all cases more than enough to cover the extra labor, equipment and fuel costs involved.

3. Grinding finer than through the $13 \mathrm{~mm}(1 / 2 ")$ screen was not economically sound.

4. It was doubtful that processing the good quality alfalfa finer than through the $25 \mathrm{~mm}$ ( $1 "$ ) screen was justified, particularly when feeding ground hay alone. [If feeding the ground hay in a complete ration (i.e. with processed grain, supplements, and additives), the finer grinding may be justified due to the reduced tendency for ration ingredients to "settle out" from the smaller-particled forage component, in the self-feeder or in the handling of the ration following mixing.]

5. There was no benefit to be gained by grinding more finely than through a $13 \mathrm{~mm}$ screen.

Table 15. Effect of processing hay on performance of steer calves (hays as fed, approx. 90\% DM)

\begin{tabular}{|c|c|c|c|c|c|c|c|c|}
\hline Forage & Process & $\begin{array}{c}\text { Average } \\
\text { initial } \\
\text { weight } \\
(\mathrm{kg})\end{array}$ & $\begin{array}{c}\text { Average } \\
\text { daily } \\
\text { gain } \\
\text { (kg) }\end{array}$ & $\begin{array}{l}\text { Average } \\
\text { daily } \\
\text { feed } \\
\text { (kg) }\end{array}$ & $\begin{array}{l}\text { Feed:Gain } \\
\text { ratio }\end{array}$ & $\begin{array}{l}\text { Gain/tane } \\
\text { hay (kg) }\end{array}$ & $\begin{array}{l}\text { Relative } \\
\text { value in } \\
\text { hays* } \\
\text { (\$) }\end{array}$ & $\begin{array}{l}\text { Increase in } \\
\text { value by } \\
\text { processing } \\
\text { (\$/tane) }\end{array}$ \\
\hline \multirow{4}{*}{$\begin{array}{r}\text { Sweetclover } \\
(11.3 \% \mathrm{CP})\end{array}$} & Lang & 241 & 0.41 & 5.73 & 14.0 & 71.4 & 53.00 & - \\
\hline & Chopped & 240 & 0.59 & 6.77 & 11.5 & 87.0 & 74.28 & 21.28 \\
\hline & Ground (51 mm) & 241 & 0.69 & 7.77 & 11.3 & 88.5 & 78.54 & 25.54 \\
\hline & Ground (13 mm) & 240 & 0.81 & 8.55 & 10.6 & 94.3 & 89.22 & 36.22 \\
\hline \multirow{4}{*}{$\begin{array}{l}\text { Marsh Hay } \\
(9.5 \% \text { CP) }\end{array}$} & Lang & 271 & 0.32 & 5.45 & 17.1 & 58.4 & 43.00 & - \\
\hline & Chopped & 272 & 0.44 & 6.68 & 15.3 & 63.4 & 34.28 & -8.72 \\
\hline & Ground (51 mm) & 272 & 0.47 & 7.00 & 15.0 & 66.7 & 42.27 & -0.73 \\
\hline & Ground (13 mm) & 271 & 0.55 & 7.45 & 13.7 & 73.0 & 50.23 & 7.23 \\
\hline \multirow{4}{*}{$\begin{array}{l}\text { Timothy-Alfalfa } \\
\text { (13.6\% CP) }\end{array}$} & Lang & 290 & 0.85 & 10.59 & 12.4 & 80.6 & 60.00 & - \\
\hline & Chopped & 290 & 1.07 & 10.77 & 10.0 & 100.0 & 90.53 & 30.53 \\
\hline & Ground (51 mm) & 290 & 1.03 & 11.27 & 10.9 & 91.7 & 73.89 & 13.89 \\
\hline & Ground (13 mm) & 290 & 1.12 & 11.27 & 10.1 & 99.0 & 86.21 & 26.21 \\
\hline \multirow{4}{*}{$\begin{array}{l}\text { Sweetclover } \\
(14.2 \% \text { CP) }\end{array}$} & Long & 240 & 0.35 & 7.39 & 21.1 & 49.4 & 37.00 & - \\
\hline & Chopped & 240 & 0.45 & 6.44 & 14.3 & 69.9 & 68.00 & 31.00 \\
\hline & Ground (51 mm) & 240 & 0.65 & 8.16 & 12.6 & 79.4 & 89.82 & 52.82 \\
\hline & Ground (13 mm) & 240 & 0.71 & 8.16 & 11.5 & 87.0 & 103.88 & 66.88 \\
\hline
\end{tabular}

*Assuming base values of lang hay as shown, crediting processed hay with the value of additional liveweight gain/tane (a) $\$ 2.20 / \mathrm{kg}$ and deducting estimated labor $(\$ 7 / \mathrm{hr})$, fuel $(40 \mathrm{t} / \mathrm{L})$, and machinery upkeep cost of $\$ 10 / \mathrm{hr}$.

\section{Comments (Table 15)}

1. Average daily gain, feed intake and feed per unit of gain improved as the hays were more finely processed, except for the timothy-alfalfa hay 
which, when fed in the long form, supported a higher rate of gain than any of the other ground hays.

2. Processing the sweetclover hays was economically sound, with the value of the hay increasing with increasingly finer processing. (Sweetclover hay tends to be stemmy, which probably reduces it acceptability relative to other finer stemmed or leafier hays.)

3. Processing the marsh hay was more expensive than for the other hays, with the result that only processing through the $13 \mathrm{~mm}(1 / 2$ " screen) was economical.

\section{EFFECT OF GRINDING HAY ON PERFORMANCE OF STEER CALVES FED FOR EQUAL RATE OF GAIN}

Self-feeding chopped or ground hay to growing steers calves improved feed intake, rate of gain and efficiency of feed utilization compared to calves fed unprocessed hay. Whether this was due to the grinding per se or the increased intake, or both was not known. Consequently, a feeding trial involving individually-fed, $285 \mathrm{~kg}$ Hereford steer calves was carried out in each of three successive years to determine the effect of processing either the forage portion of the ration or the entire ration, when feed intake was limited to that required to maintain a rate of gain of $0.45 \mathrm{~kg}$ per head per day. The ration comprised about $70 \%$ roughage (hay and straw), $20 \%$ grain and $10 \%$ of a protein, mineral, vitamin $A$ and antibiotic supplement.

The results are shown in Table 16 .

Table 16. Effect of processing hay on performance of steer calves fed for the same rate of gain (average 3 years - 178 day feeding period)

\begin{tabular}{|c|c|c|c|c|}
\hline & $\begin{array}{c}\text { Lot \#1 } \\
\text { Fed } \\
\text { long } \\
\text { forage }\end{array}$ & $\begin{array}{c}\text { Lot \#2 } \\
\text { Fed } \\
\text { chopped } \\
\text { forage }\end{array}$ & $\begin{array}{l}\text { Lot \#3 } \\
\text { Ration } \\
\text { ground } \\
(0.8 \mathrm{~cm} \\
\text { screen) }\end{array}$ & $\begin{array}{c}\text { Lot \#4 } \\
\text { Ration } \\
\text { pelleted } \\
(0.5 \mathrm{~cm} \\
\text { die) }\end{array}$ \\
\hline Number of calves & 24 & 24 & 24 & 24 \\
\hline Average initial weight $(\mathrm{kg})$ & 284 & 285 & 285 & 287 \\
\hline Average daily gain (kg) & 0.45 & 0.46 & 0.46 & 0.45 \\
\hline Average daily feed eaten (kg) & 5.32 & 5.45 & 5.59 & 5.23 \\
\hline Feed:gain ratio & 11.6 & 12.0 & 12.2 & 11.6 \\
\hline Average daily gain on pasture $(\mathrm{kg})$ & 0.92 & 0.95 & 0.91 & 0.90 \\
\hline
\end{tabular}




\section{Comment (Table 16)}

1. Processing the forage component of the ration is only beneficial when it results in a significant increase in intake and should not be done when the livestock involved can meet their nutritional requirements on unprocessed hay.

\section{FACTORS AFFECTNG THE ENERGY REQUIRED TO GRIND HAY}

Because of the beneficial effects of processing hay on the performance of growing beef calves, it was deemed necessary to determine the fuel consumption and processing rate involved in preparing ground hay-based rations.

In earlier studies, it was determined that fuel consumed in grinding rectangular bales through a grinder-mixer fitted with a $13 \mathrm{~mm}(1 / 2$ ") screen ranged from 5.66 litres (L) per tonne for alfalfa to $17.9 \mathrm{~L} /$ tonne for straw. When grinding loose hay (from the hay drying tower) more fuel was required because of the uneven unloading rate and the low load:power ratio. Shredding round crested wheatgrass bales with a McKee round bale shredder and feeding the material into a New Holland grinder-mixer resulted in an unacceptable fuel requirement $(22.2 \mathrm{~L} /$ tonne) due to the requirement to use two tractors and the difficulty in maintaining a steady and optimum flow of hay through the system. A more efficient system will have to be devised if round bales are to be ground and mixed into complete rations.

It is not normally thought that mixing and unloading require much power but this study showed that $40 \%$ of the fuel consumed in ration preparation was required for this operation due to the amount of time involved. Using tractor-generated power to operate a grain roller was very inefficient.

Fuel consumption and work rate when grinding alfalfa and crested wheatgrass bales containing different moisture levels through screens of three different sizes, are shown in Figs. 5 and 6 . A $75 \mathrm{Kw}$ tractor and a Bearcat Model 1260 grinder-mixer were used for this study. At a very low moisture content, fuel consumption was low, regardless of screen size. Fuel consumption sharply increased at higher moisture levels, with the greatest increases occurring when the smaller screens were used. Associated with the increased fuel consumption is a reduction in work rate. With alfalfa bales containing $18 \%$ moisture, partial clogging of the screen restricted through put. Processing crested wheatgrass required more energy and time than processing alfalfa. 

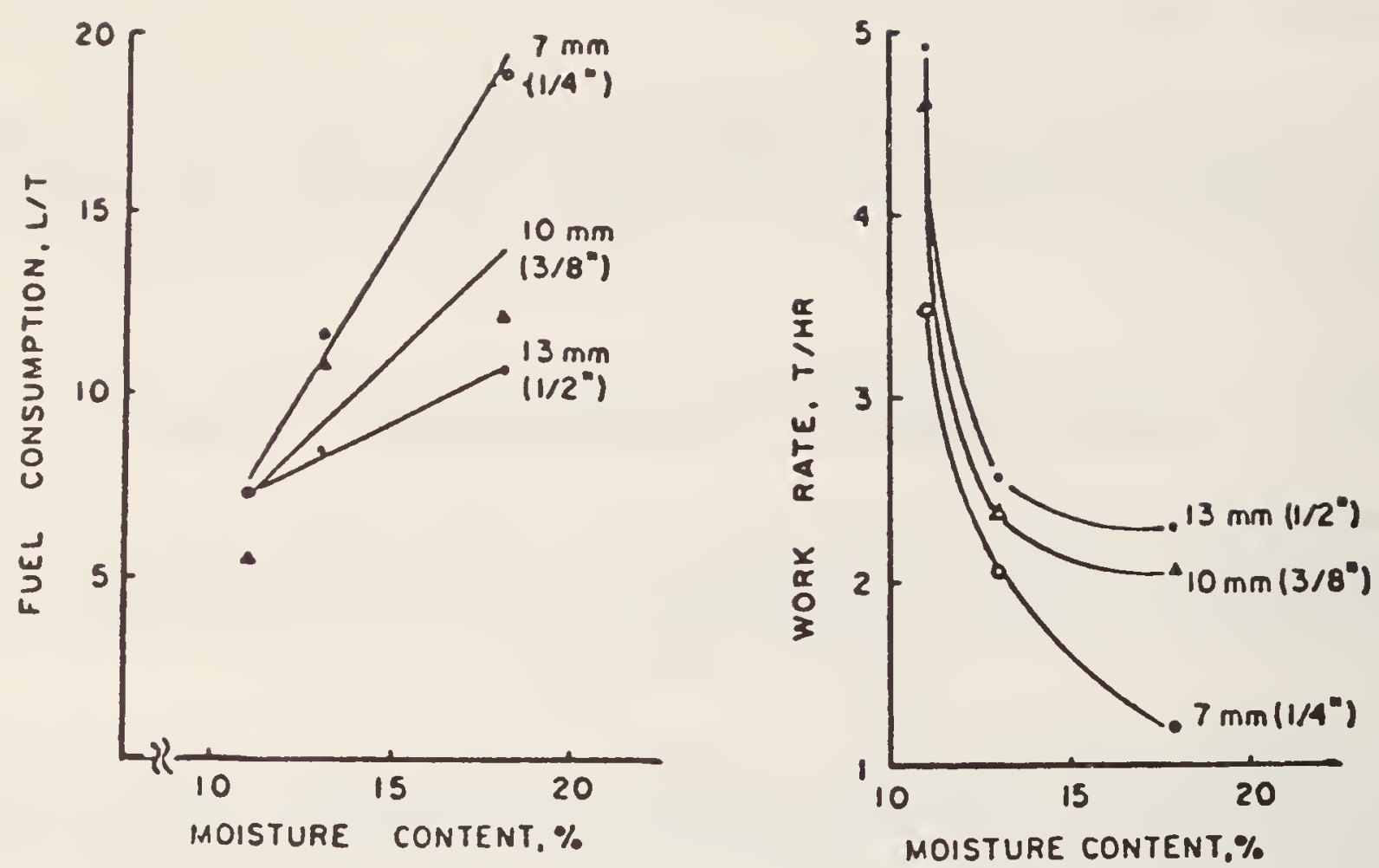

Fig. 5. Fuel consumption and work rate when grinding alfalfa bales of different moisture contents through screens of different sizes.
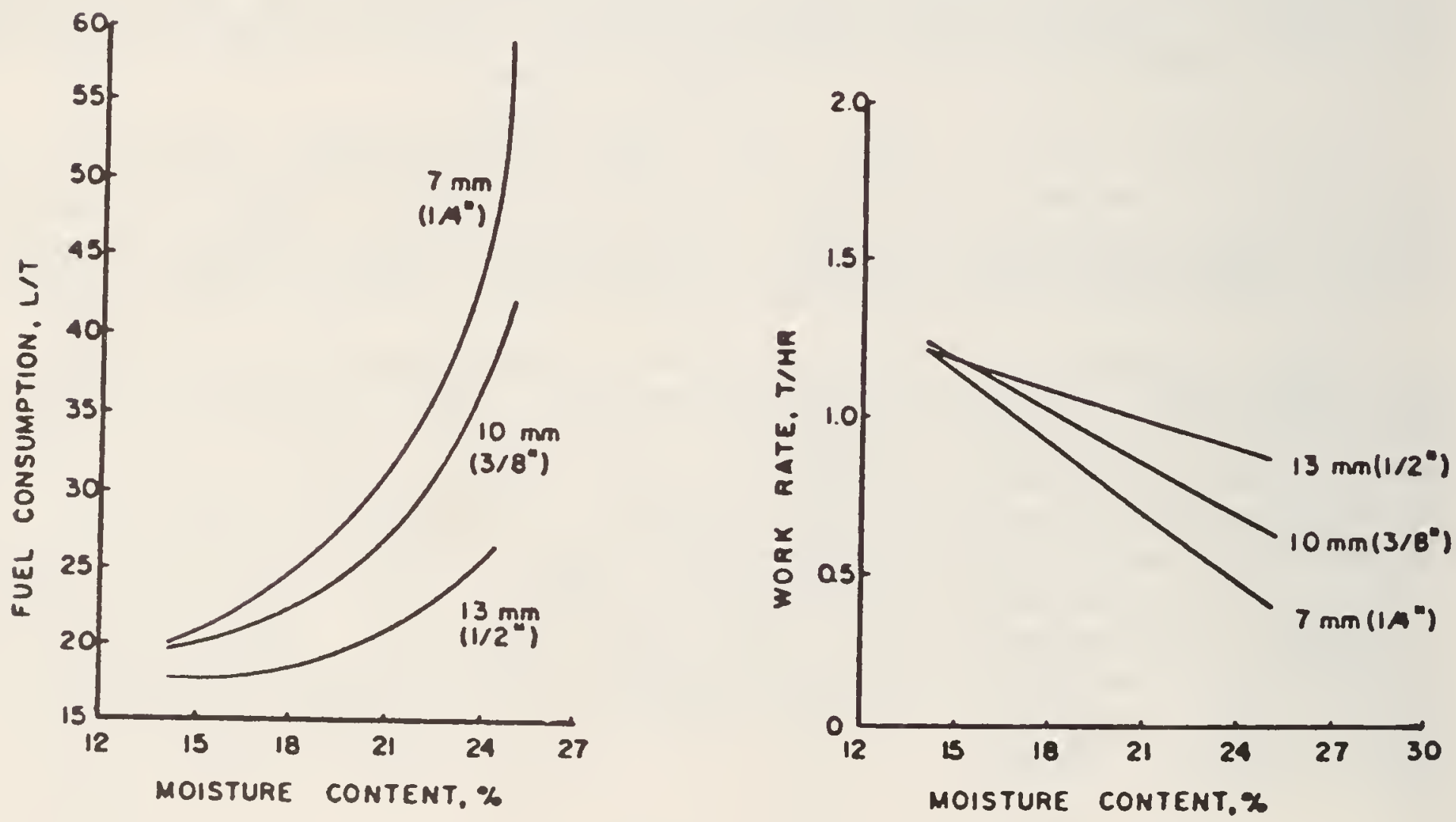

Fig. 6. Fuel consumption and work rate when gridning crested wheatgrass bales of different moisture contents through screens of different sizes. 
It is concluded that where hays are to be ground, harvesting, storage and handling systems he designed to result in as dry a hay as possible, consistent with minimal leaf loss (perhaps a hay drying system) and that the use of electrical power, which costs about one-third that of diesel generated power, be used, if feasible. Obviously hammers and screens should be maintained in good condition.

\section{FEEDING STEER CALVES FORAGE-BASED RATIONS}

\section{A COMPARISON OF THREE GRASS HAYS FED TO GROWING STEER CALVES}

Because of its ability to establish and produce on saline land, tall wheatgrass may become more available as a feed for livestock. An experiment was carried out to compare the feeding value of tall wheatgrass, bromegrass and crested wheatgrass, self-fed in the ground form $(1.27 \mathrm{~cm}$ screen) to 235 $\mathrm{kg}$ steer calves over a 146 day period. The ground hays constituted $96 \%$ of the ration, with the remainder of the ration was made up of $21 / 2 \%$ acidulated fatty acids (AFA), plus minerals, vitamin $A$ and an antibiotic. The calves had free access to cobalt-iodized block salt, a salt-calcium phosphate mineral mix and water. The results are summarized in Table 17.

Table 17. The effect of type of hay on the performance of $235 \mathrm{~kg}$ steer calves (146 days, 16 hd/ration)

\begin{tabular}{lrrr}
\hline Hay (ground) & Bromegrass & $\begin{array}{c}\text { Crested } \\
\text { wheatgrass }\end{array}$ & $\begin{array}{c}\text { Tall } \\
\text { wheatgrass }\end{array}$ \\
\hline Average daily gain (kg) & 0.82 & 0.91 & 1.14 \\
Average daily feed (kg) & 9.54 & 8.78 & 9.84 \\
Average final weight (kg) & 355 & 369 & 402 \\
Feed:gain ratio & 11.6 & 9.6 & 8.6 \\
Total feed consumed/head (kg) & 1392 & 1282 & 1437 \\
Feed cost/kg gain (c) & 78 & 68 & 68 \\
Value of gain less feed and processing & & & 195.97 \\
$\quad$ (fuel) cost (\$) & 131.29 & 156.54 & 87.4 \\
Feed Analysis: & & & 11.6 \\
- Dry matter (\%) & 86.0 & 87.9 & 51.5 \\
- Crude protein (\%) & 8.4 & 9.6 & 7.7 \\
- Digestible organic matter (\%) & 46.5 & 46.9 & 5.1 \\
- Ash (\%) & 8.4 & 6.4 & 4.3 \\
Litres fuel/tonne to grind & 6.2 & 7.0 & 3.4 \\
Tonnes processed/hour & 3.5 & & \\
\hline
\end{tabular}


1. Considering the chemical analyses of the hays, rate of liveweight gain and feed conversion efficiencies were quite good.

2. Valuing the hays at $\$ 50, \$ 55$ and $\$ 66$ per tonne (relative to their crude protein content), the value of the liveweight gains @ $\$ 1.87 / \mathrm{kg}$ exceeded the feed ingredient and "fuel to process" costs by $\$ 131, \$ 157$ and $\$ 196$ per head, for the bromegrass, crested wheatgrass and tall wheatgrass fed steers, respectively, (diesel fuel (a $40 \mathrm{~d} / \mathrm{L}$ ).

\section{ADDING ACIDULATED FATTY ACIDS (AFA) TO A CRESTED WHEATGRASS HAY AND WHEAT RATION FOR GROWING STEER CALVES}

A high energy by-product of the manufacture of canola oil (AFA) was evaluated as a supplement to a growing ration for steer calves fed a ration based on ground $(1.27 \mathrm{~cm}$ screen), crested wheatgrass hay (93\% DM, $11.4 \% \mathrm{CP}$ and $49.6 \% \mathrm{DOM}$ ) and rolled wheat. The AFA was fed at $3 \%$ of the ration. The results are summarized in Table 18.

Table 18. Adding acidulated fatty acids to a steer calf growing ration (18 head/treatment, 84 day test)

$\frac{\text { Lot \#1 }}{\text { Control }} \quad \frac{\text { Lot \#2 }}{3 \% \text { A.F.A. }}$

Average initial weight $(\mathrm{kg})$

Average final weight $(\mathrm{kg})$

Average daily gain $(\mathrm{kg})$

Total feed/head ( $\mathrm{kg}$ )

- crested wheatgrass hay (kg)

- rolled wheat $(\mathrm{kg})$

- A.F.A.

Mineral, vitamin $A$ and antibiotic supp.

Feed/unit gain

12.0 20.5

Feed* cost/head (including processing) Feed cost/kg gain ( $c$ ) Value** of gain less feed costs/hd (\$)

61.83

*Crested wheatgrass hay, \$65/tonne; wheat, $11 \not / \mathrm{kg} ; A . F . A ., 35 k / \mathrm{kg} ; \mathrm{salt}$, $31 \mathrm{k} / \mathrm{kg}$; calcium phosphate, $70 \mathrm{~d} / \mathrm{kg}$; Vitamin supplement, $\$ 2.64 / \mathrm{kg}$; Aurofac $10, \$ 1.76 / \mathrm{kg} ;$ grinding-mixing, $\$ 6.60 /$ tonne. **Assuming gains worth $\$ 2.20 / \mathrm{kg}$. 
Comment (Table 18)

The addition of A.F.A. to a ration which was supporting an excellent rate of gain and exceptional feed:gain ratio, improved rate of gain by $14 \%$ and feed efficiency by over $11 \%$, increasing the value of animal gain, less feed and processing costs by $\$ 25$ per head.

RESPONSE OF STEER CALVES FED A GROUND CRESTED VHEATGRASS RATION, TO IMPLANTATION VITH RALGRO AND SUPPLEMENTATION VITH ACIDULATED FATTY ACIDS

Crested wheatgrass has not been used extensively in the Aspen parkbelt, presumably because it was considered a dryland grass. However, the performance of the grass has been remarkedly good, both in terms of yield, the ease with which it can be made into hay, and its excellent feeding value both as hay and pasture, providing in the latter case it is managed to prevent heading.

To further evaluate the performance of growing calves fed on a ground, crested wheatgrass-based growing ration and to determine the effect of implanting with Ralgro and supplementing with A.F.A., a feeding trial was carried out with $36,214 \mathrm{~kg}$, newly-weaned crossbred steer calves, over a 63 day feeding period. The calves were self-fed in four lots on either of two rations formulated as follows, with one lot on each ration receiving a $24 \mathrm{mg}$ implant of Ralgro at the start of the test.

Ground ( $1.27 \mathrm{~cm}$ screen) crested wheatgrass

Canola meal

Cobalt-iodized, trace mineralized salt

4.0

4.0

Calcium phosphate

0.5

0.5

Vitamin ADE supplement

0.5

0.5

TM 10

Ration dry matter (\%)

0.02

0.02

0.05

0.05

Crude protein (\% of DM)

84.5

84.8

12.8

12.9

The results are summarized in Table 19 . 
Table 19. Effect of implant and AFA on the utilization of a crested wheatgrass-based ration for growing steer calves (63 day test, 9 head/ration)

\begin{tabular}{lrrrr}
\hline & \multicolumn{3}{c}{ Ration Treatment } \\
\cline { 2 - 5 } & \multicolumn{1}{c}{$\begin{array}{r}4 \\
\text { Control }\end{array}$} & $\begin{array}{r}\text { Control } \\
\text { + Ralgro }\end{array}$ & $\begin{array}{c}\text { Control } \\
+ \text { AFA }\end{array}$ & $\begin{array}{r}\text { Control } \\
\text { Ralgro } \\
\text { AFA }\end{array}$ \\
\hline & 295 & 297 & 297 & 303 \\
Av. final weight (kg) & 1.29 & 1.32 & 1.33 & 1.43 \\
Av. daily gain (kg) & 6.66 & 6.43 & 6.33 & 6.17 \\
Feed:gain ratio (90\% DM) & 1192 & 1178 & 1169 & 1221 \\
Total feed/animal (kg 90\% DM) & 178.20 & 184.80 & 184.80 & 198.00 \\
Value of liveweight gain @ \$2.20/kg (\$) & 45.36 & 51.01 & 53.46 & 57.59 \\
Value of feed + implement (\$) & 132.84 & 133.79 & 131.34 & 140.41 \\
Value of gain less feed \& implant (\$) & & & & \\
\hline
\end{tabular}

\section{Comments (Table 19)}

1. Rate of gain and feed conversion efficiency of calves fed the control ration (75\% ground grass hay) were excellent for calves of this size.

2. Use of the implant and of AFA improved both rate of gain and feed conversion efficiency and the combination of the two resulted in an additive effect.

3. When the implant was used in combination with the AFA, returns over feed and implant cost was about $\$ 8 /$ head over that of the control animals.

4. The excellent performance of these calves may in part be due to the use of a protein supplement. (0ther studies indicate that despite the theoretical adequacy of crude protein level in a hay or grain-based ration, there may be a benefit to adding additional protein.)

\section{EPFECT OF AMMONIATING HAY ON ITS FEEDING VALUE FOR GROWING STEERS}

Considerable losses in both quantity and quality of hay occur due to problems encountered during harvesting. Over-dry hay, particularly, legumes, can lose feeding value due to excessive loss of leaves during raking, baling or field chopping, while considerable molding can occur during storage when hay is harvested at too high a moisture content.

Anhydrous ammonia ( $2 \% \mathrm{wt} / \mathrm{wt}$ ) has been found to destroy molds, yeasts and bacteria when used to treat high moisture hay, and thus offers a useful technique when farmers are faced with having to put up hay at a higher-than-normal, moisture content. Anhydrous ammonia also increases the 
non-protein nitrogen content of hay and has been found to increase the level of digestible energy, particularly of high fibre feedstuffs such as cereal straw, by hydrolyzing cellulose.

To investigate the effect of ammoniating hays on their feeding value, an experiment was undertaken at Melfort, in each of three successive years, in which brome-alfalfa and alfalfa hays, harvested at two moisture levels $(<20$ and $30 \%)$ were ammoniated ( $2 \% \mathrm{wt} / \mathrm{wt})$ and compared to field-cured $(<20 \%$ moisture) non-ammoniated hay. The hays were harvested as large round bales and treatment with ammonia carried out in plastic-covered stacks. A feeding trial with steers and a digestibility trial with sheep were conducted.

The key findings are summarized in Table 20.

Table 20. Effects of ammoniating hay on chemical composition and feeding value

\begin{tabular}{|c|c|c|c|c|c|c|}
\hline & \multicolumn{3}{|c|}{ Brome-Alfalfa } & \multicolumn{3}{|c|}{ Alfalfa } \\
\hline & \multirow{2}{*}{$\frac{\text { Field-cured }}{17 \%}$} & \multicolumn{2}{|c|}{ Ammoniated } & \multirow{2}{*}{$\begin{array}{c}\frac{\text { Field-Qured }}{17 \%} \\
\text { moisture }\end{array}$} & \multicolumn{2}{|c|}{ Ammoniated } \\
\hline & & $\begin{array}{c}18 \% \\
\text { moisture }\end{array}$ & $\begin{array}{c}31 \% \\
\text { moisture }\end{array}$ & & $\begin{array}{c}19 \% \\
\text { moisture }\end{array}$ & $\begin{array}{c}29 \% \\
\text { moisture }\end{array}$ \\
\hline \% Dry matter recovery (14 wk) & 97 & 99 & 98 & 97 & 99 & 94 \\
\hline - Crude protein $(\%)$ & 11.6 & 17.4 & 19.0 & 17.7 & 23.4 & 24.8 \\
\hline \multicolumn{7}{|l|}{ Steer Performance ( 3 yr. av.) } \\
\hline Dry matter intake - kg/day & 8.3 & 8.2 & 8.8 & 9.1 & 8.7 & 8.1 \\
\hline$-\%$ body wt. & 2.39 & 2.45 & 2.55 & 2.61 & 2.50 & 2.34 \\
\hline Average daily gain (kg) & 0.84 & 0.84 & 0.82 & 0.80 & 0.76 & 0.83 \\
\hline Feed:gain ratio & 10.1 & 10.2 & 11.2 & 11.4 & 11.5 & 9.8 \\
\hline \multicolumn{7}{|l|}{ Sheep Performance ( 2 yr. av.) } \\
\hline Dry matter intake (\% body wt.) & 2.89 & 3.07 & 3.14 & 3.13 & 3.22 & 3.05 \\
\hline Dry matter digestibility & 61 & 63 & 58 & 55 & 56 & 58 \\
\hline Nitrogen digestibility & 60 & 57 & 43 & 67 & 68 & 63 \\
\hline Rumen pH & 6.9 & 7.0 & 7.0 & 7.0 & 7.1 & 7.3 \\
\hline
\end{tabular}

\section{Comments (Table 20)}

1. $2 \%$ ammonnia in plastic-covered stacks (cost $\$ 13 /$ tonne of DM) was adequate to preserve large round brome-alfalfa and alfalfa bales harvested at $30 \%$ moisture.

2. Cattle fed ammoniated low or high moisture hays performed about the same as those fed the field-cured non-ammoniated hay, although ammoniating the high moisture brome-alfalfa hay tended to reduce feed efficiency while the reverse was true with the alfalfa hay.

3. The high moisture hay was prevented from undergoing spoilage, through the use of ammonia, where it might otherwise have suffered a serious loss in feeding value. 
BFFECT OF SUPPLEMENTAL GRAIN, AND OF IMPLANTING, ON THE PERFORMANCE OF STEER CAI.VF.S FFD BARI.FY-SJ.LAGE

Because silage tends to be bulky, due to its high moisture content, relative to hay, it is not normally fed to growing calves as the major portion of the ration. For producers who normally rely on silage for their feeding operations, it is important to know how to improve the performance of growing calves. One common method is to supplement the silage with grain, thereby increasing energy intake. Another possibility for improving rate of gain and feed utilization is to use growth promoting implants.

Ninety-six crossbred steer calves (Charolais-sired out of Angus $x$ Hereford and Simmental x Hereford cows) were assigned, on the basis of weight and breeding, to six, uniform lots, and the ration and implant treatments assigned at random to the lots. All lots of calves received barley silage (39\% DM, $11.2 \% \mathrm{CP}, 52.7 \% \mathrm{DOM})$ ) on an ad libitum basis, three received dry rolled barley at the rate of $2 \mathrm{~kg} / \mathrm{head} /$ day, and, within each ration type (silage or silage + grain) three implant treatments (control, Ralgro and Synovex S) were administered. All calves had free access to salt and a calcium-phosphorus $(1: 1)$ supplement. The results are shown in Table 21 .

Table 21. The effect of supplementing silage with grain on the performance of implanted and non-implanted growing beef steers (139 days, 16 calves/treatment)

\begin{tabular}{|c|c|c|c|c|c|c|}
\hline \multirow[b]{2}{*}{ Implant treatment } & \multicolumn{3}{|c|}{ Silage } & \multicolumn{3}{|c|}{ Silage + Grain } \\
\hline & Control & Ralgro & Symovex S & Control & Ralgro & Synovex S \\
\hline Average initial weight (kg) & 264 & 265 & 267 & 265 & 268 & 269 \\
\hline Average daily gain (kg) & 0.70 & 0.76 & 0.80 & 0.88 & 0.95 & 1.05 \\
\hline Average daily dry matter eate & & & & & & \\
\hline - silage & 6.4 & 6.0 & 6.0 & 5.0 & 5.1 & 5.9 \\
\hline Total & $\overline{6.4}$ & $\overline{6.0}$ & $\overline{6.0}$ & 6.7 & $\frac{1.1}{6.8}$ & 7.6 \\
\hline Dry matter:gain ratio & 9.1 & 8.0 & 7.8 & 7.6 & 7.1 & 7.2 \\
\hline
\end{tabular}

*Silage \& \$66/tome DM; grain \& \$110/tanne DM; liveweight gains \& \$2/kg; Ralgro \& \$1.35 and Synovex e $\$ 1.75$.

Comments (Table 21)

1. Feeding barley increased rate of gain by an average of $27 \%$ and feed conversion efficiency by $11 \%$, with the greatest improvement in feed efficiency occurring with the unimplanted animals.

2. Ralgro improved rate of gain by $8.0-8.5 \%$ for steers fed either ration, while Synovex increased rate of gain by $14 \%$ for steers fed the silage ration and $31 \%$ for steers fed the silage plus grain ration. 
3. Ralgro produced a similar response in rate of gain for steers fed either ration, while synovex produced a greater response in steers fed the silage + grain ration. However, the effect of the implants on feed conversion efficiency was more marked ( 12.5 vs $0.6 \%$ ) with the silage ration.

4. Feeding barley increased returns over feed and implant costs by $\$ 42$ per head, the use of Ralgro by $\$ 18$ per head and the use of Synovex $\mathrm{S}$ by $\$ 37$ per head.

\section{FEEDING HEIFER CALVES FORAGE-BASED RATIONS}

\section{GROWING RATIONS FOR BEEF HEIFERS}

Beef heifer calves, weaned off pasture in the fall, can be grown out the first winter on a wide variety of rations, provided of course, that their energy, protein, mineral and vitamin requirements are met. Normally, lowest cost rations are advised for cattle being grown for the slaughter market, but in the case of heifers being raised for breeding stock, the kind of feed during the growing period has an influence on future reproductive performance. According to studies carried out at the Lethbridge Research Station, rations for such heifers should be based on good quality hay or silage. Care should be taken to feed rations that promote growth (i.e. muscular development) rather than fattening. The rate of gain must be adequate to assure that heifers are of sufficient size to allow them to be bred to calve at two years of age. Good forage-based wintering rations and access to good pastures should achieve this goal.

It is particularly important that adequate minerals be available, either in the ration and/or in blocks or mineral boxes on a free choice basis. When heifers are being fed good quality hay or pasture they will be getting adequate amounts of calcium but will need additional phosphorus. Providing vitamin $A$ by injection or in the feed will be required during the wintering period if the hay is not of a bright green color or if the ration is based on grain and straw.

Performance of growing heifer calves, on several rations formulated to equalize rate of gain, is shown in Table 22. Since optimum rate of gain will differ with the breed of cattle, feeders should always watch cattle closely and adjust the ration accordingly, to either increase or reduce rate of gain. 
Table 22. Performance of growing beef heifers fed different rations to produce the same rate of gain

\begin{tabular}{|c|c|c|c|c|c|c|}
\hline & & $\begin{array}{l}\text { Brome- } \\
\text { alfalfa } \\
\text { hay }+ \\
\text { grain }\end{array}$ & \multicolumn{2}{|c|}{$\begin{array}{l}\text { Barley } \\
\text { silage, } \\
\text { straw + } \\
\text { grain }\end{array}$} & $\begin{array}{l}\text { Sweet } \\
\text { clover } \\
\text { silage } \\
+ \text { straw } \\
+ \text { grain }\end{array}$ & $\begin{array}{l}\text { Complete } \\
\text { ground } \\
\text { ration }\end{array}$ \\
\hline $\begin{array}{l}\text { Average initial weight }(\mathrm{kg}) \\
\text { Average final weight }(\mathrm{kg}) \\
\text { Average daily gain }(\mathrm{kg})\end{array}$ & & $\begin{array}{r}242 \\
363 \\
0.71\end{array}$ & $\begin{array}{r}237 \\
360 \\
0.72\end{array}$ & & $\begin{array}{r}240 \\
359 \\
0.70\end{array}$ & $\begin{array}{r}240 \\
359 \\
0.70\end{array}$ \\
\hline $\begin{array}{l}\text { Average daily feed* }(\mathrm{kg}) \\
\text { - forage } \\
\text { - straw } \\
\text { - grain } \\
\text { - canola meal }\end{array}$ & & $\begin{array}{c}\frac{8.48}{7.22} \\
- \\
1.22 \\
-\end{array}$ & $\begin{array}{l}\frac{7.47}{5.51} \\
0.55 \\
1.32 \\
-\end{array}$ & & $\begin{array}{l}7.87 \\
5.15 \\
0.96 \\
1.70 \\
-\end{array}$ & $\begin{array}{l}9.00 \\
0.34 \\
5.49 \\
2.18 \\
0.84\end{array}$ \\
\hline \multirow[t]{2}{*}{ Feed:gain ratio } & & 12.0 & 10.2 & & 11.3 & 12.9 \\
\hline & $\begin{array}{l}\text { Brome- } \\
\text { alfalfa }\end{array}$ & $\begin{array}{l}\text { Barley } \\
\text { silage }\end{array}$ & $\begin{array}{l}\text { Sweet } \\
\text { clover } \\
\text { silage }\end{array}$ & $\begin{array}{r}\text { Barley } \\
\text { straw }\end{array}$ & Wheat & $\begin{array}{c}\text { Complete } \\
\text { ration }\end{array}$ \\
\hline \multicolumn{7}{|l|}{ Chemical analyses (\%) } \\
\hline $\begin{array}{l}\text { - dry matter } \\
\text { - crude protein (DM) } \\
\text { - digestible organic } \\
\text { matter (DOM) }\end{array}$ & $\begin{array}{l}85.0 \\
11.7\end{array}$ & $\begin{array}{l}39.9 \\
11.8\end{array}$ & $\begin{array}{l}37.3 \\
15.0\end{array}$ & $\begin{array}{r}83.7 \\
6.9\end{array}$ & $\begin{array}{l}86.3 \\
17.0\end{array}$ & $\begin{array}{l}82.9 \\
10.3\end{array}$ \\
\hline
\end{tabular}

*90\% dry matter basis, includes mineral, vitamin $\mathrm{A}$ and anitibiotic supplements.

\section{A COMPARISON OF FORAGE-BASED VS GRAIN-BASED RATIONS FOR WINTERING HEIFER CALVES}

Heifer calves destined for finishing in the feedlot can be grown out on a wide variety of rations. The choice of ration will depend on the available feeds either produced or purchased, the relative cost of the nutrients in these feeds and of the supplement, if any, required to balance the nutrients to most efficiently meet the needs of the livestock being fed. The desired rate of gain and the optimum market weight for the type of animal being fed should also be considered, since some rations will permit finishing at lighter weights than others and this may or may not be economically desirable. 
An experiment, involving 84 Charolais-sired, crossbred heifer calves, averaging $248 \mathrm{~kg}$ was set up to evaluate four rations as follows:

1. Brome-alfalfa hay (large round bales) $+1.45 \mathrm{~kg}$ wheat/hd/day .

2. Brome-alfalfa silage $+1.45 \mathrm{~kg}$ wheat/hd/day.

3. Wheat + straw + canola meal.

4. Wheat + ammoniated straw.

All feeds, except the concentrate allowance for the forage-fed cattle, were fed free choice or self-fed. Cattle had access to salt, a mineral mix and water free choice. The concentrate mix and the complete rations contained salt, minerals, vitamin ADE and an antibiotic. The results of the test are summarized in Table 23. Within each lot, one-third of the heifers received no implant, one-third were implanted with Ralgro and one-third with Synovex $H$. The effect of these treatments on rate of liveweight gain ( $\mathrm{kg} /$ day) is summarized by ration as follows ( 7 animals/sub-treatment).

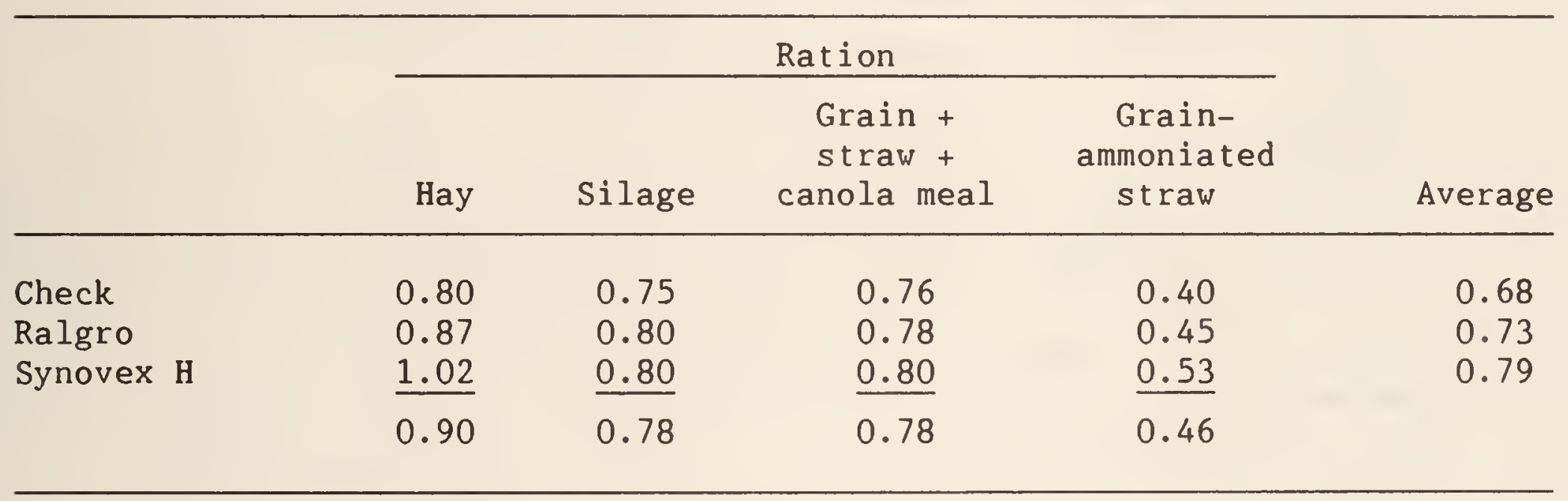

\section{Comments (Table 23)}

1. Hay-fed heifers gained faster than those on the silage ration, but ate more feed and converted it less efficiently into liveweight gain, thus returning about $\$ 6$ per head less when feed costs were subtracted from the value of the gains.

2. Heifers fed the grain and straw ration gained at the same rate as the silage-fed heifers but ate more feed and converted it less efficiently into gains, thus returning about $\$ 35$ less when feed costs were deducted from the value of the gains.

3. Ammoniation of the straw brought the protein level of the ration up to that of the wheat-straw-canola meal ration. However, the digestible organic matter (roughly TDN) level of the ration was markedly less. While the feed cost per $\mathrm{kg}$ gain was the same for heifers fed Rations 3 and 4, the reduced gains made this ration less economical. 
4. The feeding of good quality forages was superior to feeding the grain based rations.

Table 23. A comparison of rations for growing beef heifer calves

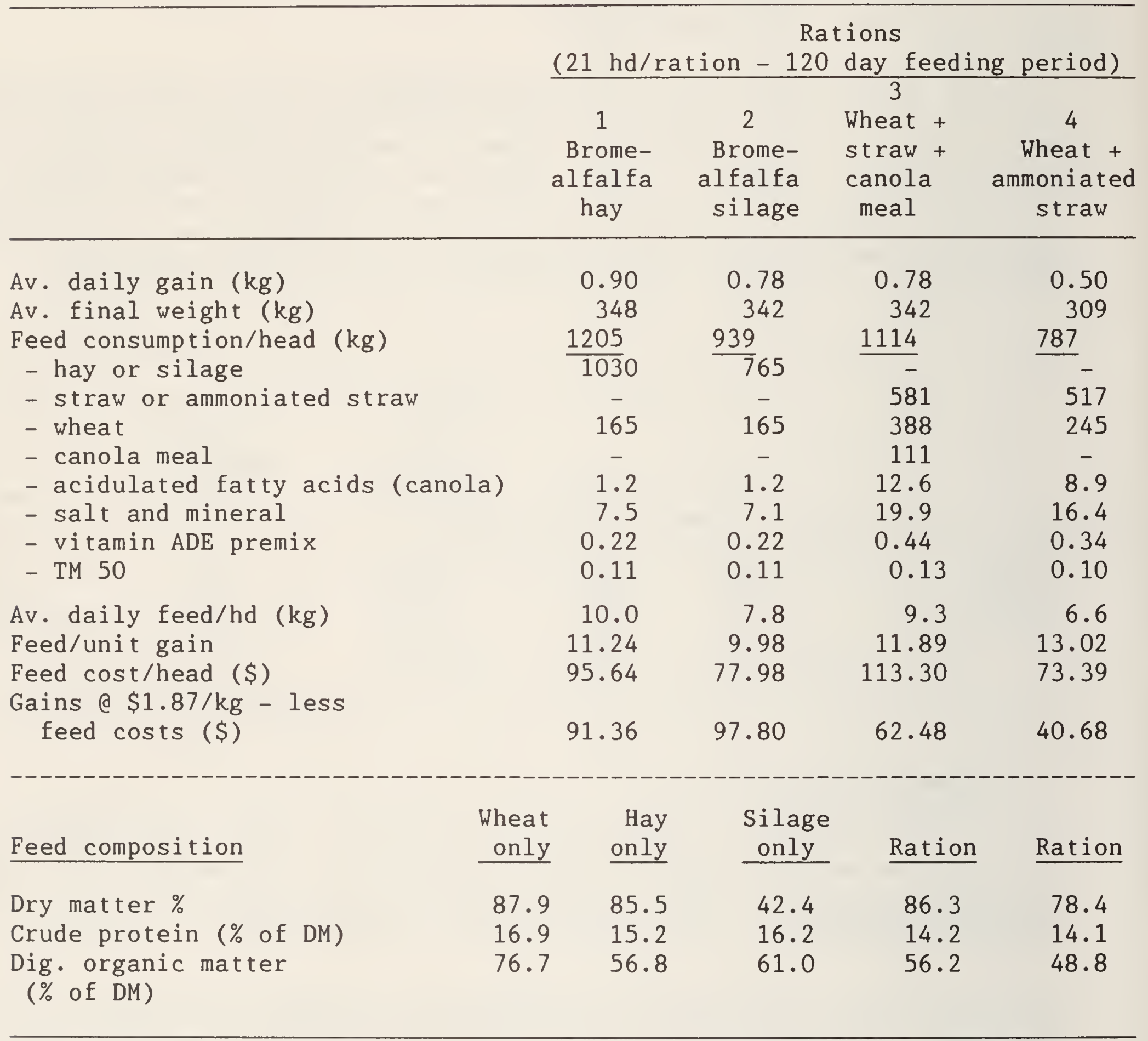

Brome-alfalfa hay, \$66/tonne; 0at straw, \$44/tonne; Br.-alf. silage, $\$ 66 /$ tonne (85.5\% DM); Ground, ammoniated straw, $\$ 52.80 /$ tonne; Wheat, $13.2 \mathrm{c} / \mathrm{kg}$; Canola meal, $\$ 220 /$ tonne; A.F.A., 35.2k/kg; Co. I. TM salt, $30.8 \mathrm{k} / \mathrm{kg}$; Calcium phosphate $\left(18 \% \mathrm{Ca}, 20.5 \% \mathrm{P}_{2} 0_{5}\right), 65 \mathrm{k} / \mathrm{kg} ;$ Vitamin ADE $(10,000$ I.U. vit. A/gm), $\$ 1.25 / \mathrm{kg}$; TM 50 (110 gm oxytetracycline $/ \mathrm{kg}), \$ 12.87 / \mathrm{kg}$.

Feed related data under Ration 4 adjusted to $86.3 \%$ DM basis (to compare with Ration 3 ) and silage adjusted to $85.5 \%$ DM to compare with Ration 1. 


\section{CRESTED UHEATGRASS VS BROME-ALFALFA FED UNPROCESSED TO GROWING HEIFERS}

Long bromegrass-alfalfa and crested wheatgrass hays, harvested under several different systems, were fed free choice to yearling beef heifers, with a fixed amount of dry rolled barley hand-fed daily. The results of this trial, averaged across harvesting systems are shown in Table 24.

Table 24. Crested wheatgrass vs bromegrass-alfalfa hays fed to growing heifers ( 27 head/treatment)

Number of heifers

Moisture content at harvest (\%)

Average daily gain $(\mathrm{kg})$

Average daily feed ( $\mathrm{kg} / \mathrm{head}$ )

- hay

- grain

Dry matter:gain ratio

Gain/tonne dry matter ( $\mathrm{kg}$ )

Crude protein (\%)

Digestible organic matter (\%)

Intake of $\mathrm{DOM} / \mathrm{head} / \mathrm{day}(\mathrm{kg})$
27

24.3

0.72

8.00

0.77

12.2

162

11.0

57.8

5.25
27

25.9

0.39

6.88

0.77

19.9

100

11.5

53.4

4.27

\section{Comment (Table 24)}

1. Despite being harvested, on average, drier than brome-alfalfa and despite its somewhat lower crude protein content, crested wheatgrass had a higher digestible organic matter content and was more palatable than the brome-alfalfa, resulting in a higher rate of gain and a better feed:gain ratio than brome-alfalfa.

\section{FEEDING TALL VHEATGRASS TO GROWING HEIFER CALVES}

One of the few crops that will establish and produce on moderately saline soil is tall wheatgrass. Because of the Melfort Station's involvement in rejuvenating an area which had become unproductive, even for barley production, a quantity of hay ( $86.5 \%$ D.M., $12.6 \%$ C.P. and $51 \%$ D.0.M.) became available for feeding to beef cattle. A feeding trial involving four lots of $290 \mathrm{~kg}$ growing crossbred beef heifers (Angus $x$ Hereford and Simmental $x$ Hereford) fed for a 60 day period, was conducted. The heifers were self-fed hay, either long, chopped or ground through $1.27 \mathrm{~cm}\left(1 / 2^{\prime \prime}\right)$ and $0.63 \mathrm{~cm}\left(1 / 4^{\prime \prime}\right)$ screens, and received 0.9 ( $2 \mathrm{lb}$.) of a concentrate mixture per head daily. The results are presented in Table 25. 
Table 25. The effect of processing tall wheatgrass on the performance of growing beef heifers ( 60 day test)

\begin{tabular}{lccrr}
\hline & $\begin{array}{c}\text { Long hay } \\
\text { (Standard } \\
\text { bale) }\end{array}$ & $\begin{array}{c}\text { Chopped } \\
\text { hay } \\
(5-8 \mathrm{~cm})\end{array}$ & $\begin{array}{r}1.27 \mathrm{~cm} \\
\text { screen }\end{array}$ & $\begin{array}{r}0.63 \mathrm{~cm} \\
\text { screen }\end{array}$ \\
\hline Average final weight (kg) & 355 & 365 & 373 & 374 \\
Average daily gain (kg) & 1.12 & 1.25 & 1.40 & 1.42 \\
Feed consumed/hd (kg) & 548 & 563 & 602 & 659 \\
- tall wheatgrass hay & 488 & 505 & 544 & 601 \\
- dry rolled wheat & 53 & 53 & 53 & 53 \\
- cobalt-iodized TM salt* & 3.6 & 2.4 & 2.8 & 2.4 \\
- calcium phosphate* & 3.1 & 2.5 & 2.1 & 2.2 \\
- Vitamin ADE premix & 0.11 & 0.11 & 0.11 & 0.11 \\
- TM 50 & 0.05 & 0.05 & 0.05 & 0.05 \\
Av. daily feed (kg) & 9.13 & 9.41 & 10.05 & 11.00 \\
Feed:gain ratio & 8.15 & 7.53 & 7.18 & 7.75 \\
Feed cost/kg gain (c)** & 63 & 56 & 53 & 57 \\
Litres fuel/tonne of hay processed & - & 3.34 & 6.11 & 7.19 \\
Processing time/tonne (min.) & - & 20.7 & 15.8 & 18.4 \\
\hline
\end{tabular}

*Includes consumption of free choice salt and mineral mix.

**Hay @ $\$ 66 /$ tonne; wheat @ $11 \mathrm{c} / \mathrm{kg}$; salt @ $31 \mathrm{c} / \mathrm{kg}$; calcium phosphate @ $65 \mathrm{c} / \mathrm{kg}$; vitamin $\operatorname{mix}(10,000 \mathrm{IU}$ vit. $\mathrm{A} / \mathrm{gm}), \$ 1.28 / \mathrm{kg}$; and TM 50 e $\$ 5.39 / \mathrm{kg}$.

\section{Comment (Table 25)}

1. Tall wheatgrass produced excellent rates of gain and feed:gain ratios when harvested at an optimum stage of maturity (crude protein content) and properly stored. Processing improved rates of gain and feed efficiency, with optimal processing with the $1.27 \mathrm{~cm}$ screen.

As a matter of interest the hay land was fertilized with $90 \mathrm{~kg} N$ and 45 $\mathrm{kg} \mathrm{P}_{2} \mathrm{O}_{5} / \mathrm{ha}$, and yielded 5.6 tonnes/ha in two cuts.

THE FEEDING VALUE OF SEVERAL SILAGES WHEN FED TO GROUING HEIFERS

During a 197 day feeding period, $218 \mathrm{~kg}$ crossbred hejer calves were used to evaluate four silages, (brome-alfalfa, barley, weedy alfalfa and a salvaged canola crop). The composition of the rations and the chemical analyses data are in Table 26. 
Table 26. Composition of silage rations fed to growing heifers

Brome-alfalfa Weedy-alfalfa Barley Canola*

Ration Composition (\% DM)

$\begin{array}{lrrrr}\text { Silage } & 78.0 & 81.1 & 78.6 & 62.7 \\ \text { Rolled wheat } & 20.0 & 17.1 & 19.5 & 33.9 \\ \text { Acidulated fatty acids } & 0.5 & 0.5 & 0.5 & 0.9 \\ \text { Cobalt-iodized salt } & 0.6 & 0.6 & 0.6 & 1.1 \\ \text { Calcium phosphate } & 0.8 & 0.6 & 0.7 & 1.3 \\ \text { Vitamin ADE premix } & 0.06 & 0.06 & 0.06 & 0.06 \\ \text { TM 50 } & 0.04 & 0.04 & 0.04 & 0.04\end{array}$

Ration Analyses

$\begin{array}{lllll}\text { Dry matter } & 51 & 46 & 40 & 52 \\ \text { Crude protein } & 15 & 18 & 16 & 16\end{array}$

Silage Analyses

Dry matter

Crude protein 15

Digestible organic matter $\quad 50$

$43 \quad 36 \quad 44$

$18 \quad 16 \quad 16$

$61 \quad 58 \quad 49$

*Canola was salvaged from windrows that had been exposed to the weather for several days. Water was added as it was ensiled. Difficulty was encountered in obtaining a uniform particle size. This, plus the initial high dry matter level, made packing difficult and led to some molding of the silage. Moldy material was removed in so far as possible at the time of feeding.

The results are summarized in Table 27.

Table 27. The feeding value of silages from several high protein crops (107 day trial)

\begin{tabular}{lrrrr}
\hline & \multicolumn{4}{c}{ Type of Silage } \\
\cline { 2 - 5 } & Brome-alfalfa & Weedy-alfalfa & Barley & Canola \\
\hline & & & \\
Av. final weight (kg) & 287 & 0.77 & 0.66 & 0.25 \\
Av. daily gain & 0.64 & 7.45 & 6.53 & 3.95 \\
Av. daily feed (DM), (kg) & 6.38 & 9.68 & 9.89 & 15.80 \\
Feed:gain ratio & 9.97 & 71.38 & 61.79 & 39.38 \\
Feed cost/head (\$) & 60.16 & 153.34 & 130.90 & 50.49 \\
Value of liveweight gain (\$) & 127.16 & 81.96 & 69.11 & 11.11 \\
a \$1.87 less feed costs* (\$) & 67.00 & & & \\
\hline *Valuing silage @ \$66, \$70, \$66 and \$50 per tonne DM, respectively, and wheat \\
a \$132/tonne.
\end{tabular}


1. Performance of the calves fed the weedy alfalfa silage, relative to those fed the barley silage, showed that good silage could be made from a high protein crop (some believe that a high protein:TDN ratio makes a crop difficult to ensile).

2. Performance of calves on the canola silage was substandard, but expected, in view of the condition of the crop at the time it was put up. These results should not be interpreted as indicating that silage made from a canola crop put up under more normal conditions would not make good feed. In some years canola crops are frozen prior to harvesting and could well be salvaged for livestock feed in the form of silage. Nitrate levels should be checked prior to feeding the silage, and the silage suitably "diluted" with other feeds, if necessary.

\section{FINISHING BEEF STEERS AND HEIFERS ON FORAGE-BASED RATIONS}

\section{HAY TO GRAIN RATIO AND THE EFFECT OF HAY QUALITY IN STEER FINISHING RATIONS}

To investigate the effect of level of ground hay on the performance of finishing steers, a test involving four lots of eight Hereford steers was carried out to evaluate rations containing 20, 50, 80 and $99 \%$ ground bromegrass hay (plus a mineral, vitamin and antibiotic supplement). The key results are summarized in Table 28.

Table 28. Effects of feeding ground hay at various levels in steer finishing rations

\begin{tabular}{|c|c|c|c|c|}
\hline & \multicolumn{4}{|c|}{ Ration } \\
\hline & $20 \%$ Hay & $50 \%$ Hay & $80 \%$ Hay & $99 \%$ Hay \\
\hline Days on test & 77 & 70 & 70 & 63 \\
\hline Average daily gain (kg) & 0.79 & 1.00 & 1.07 & 1.02 \\
\hline Average daily feed eaten ( $\mathrm{kg}$ ) & 7.2 & 8.7 & 11.5 & 11.7 \\
\hline Feed:gain ratio & 9.2 & 9.7 & 10.8 & 11.5 \\
\hline Average final weight (kg) & 459 & 459 & 462 & 458 \\
\hline Dressing \% & 53.7 & 53.2 & 52.2 & 50.6 \\
\hline Carcass grades: Choice & 3 & 8 & 4 & 2 \\
\hline Good & 3 & 0 & 4 & 5 \\
\hline Standard & 2 & 0 & 0 & 1 \\
\hline
\end{tabular}




\section{Comments (Table 28)}

1. It was demonstrated that steers could be finished on rations containing substantial amounts of ground hay.

2. Taking all cattle to a similar carcass weight was not a sound practice. Due to higher intakes of the bulky rations, steers fed the high forage rations appeared to be closer to finish than they actually were, and should have been taken to heavier liveweights to equalize carcass weights and grades across the rations containing different levels of hay.

The next step was to look at the effect of hay quality and level in rations for finishing steers. Forty-eight, steers averaging $386 \mathrm{~kg}$, were weighed directly off pasture and assigned to one of six ration treatments, comprising 20,50 and $80 \%$ of either good or poor quality ground hay. Rations were self-fed from the start, except that steers assigned to the $20 \%$ and $50 \%$ rations received the $80 \%$ hay ration for one week, then the former a $50 \%$ hay ration for a week before receiving their final ration. The key results of the 61 day test are summarized in Table 29.

Table 29. Effect of level and quality of ground hay in steer finishing rations

\begin{tabular}{|c|c|c|c|}
\hline Hay Level: & $20 \%$ & $50 \%$ & $80 \%$ \\
\hline
\end{tabular}

$\begin{array}{lrrrrrr}\text { Average daily gain (kg) } & 0.99 & 1.22 & 1.46 & 1.09 & 1.14 & 1.44 \\ \text { Average daily feed (kg) } & 11.1 & 10.2 & 13.2 & 11.4 & 12.4 & 13.0 \\ \text { Feed:gain ratio } & 11.2 & 8.4 & 9.0 & 10.3 & 10.9 & 9.0 \\ \text { Average final weight (kg) } & 446 & 460 & 475 & 454 & 456 & 477 \\ \text { Dressing \% } & 54.8 & 54.4 & 53.0 & 54.7 & 51.8 & 53.8 \\ \text { Cold carcass weight (kg) } & 244 & 250 & 252 & 248 & 237 & 257 \\ \text { Average depth of backfat (mm) } & 14 & 13 & 15 & 14 & 11 & 13 \\ \text { Carcass grades: Choice } & 2 & 2 & 3 & 2 & 1 & 2 \\ \quad \text { Good } & 5 & 5 & 4 & 6 & 5 & 6 \\ \text { Standard } & 1 & 0 & 1 & 0 & 2 & 0\end{array}$

*Good - Alfalfa and bromegrass, 14\% CP; Poor - Meadow fescue: wheat straw $(9: 1), 7.5 \% \mathrm{CP}$; Grain, $14 \% \mathrm{CP}$.

Comments (Table 29)

1. Hay quality was important at the 20 and $80 \%$ levels, with the good quality hay producing better rates of gain and feed:gain ratios than did the poor quality hay. 
2. Dressing percentages were reduced as the level of hay increased with a much greater reduction in the case of the steers fed the poorer quality forage.

3. There was a tendency for steers fed the $50 \%$ level of good quality hay (mainly alfalfa) to bloat, which reduced both rate of gain and feed efficiency. Perhaps because of this, poor quality hay gave the test performance when fed at the 50\% level while the high quality hay gave best results when fed at the $80 \%$ level.

To provide further information on the effect of hay quality and level in steer finishing rations a more extensive experiment was carried out in each of two years. In this test, good, medium and poor quality forages were ground ( $8 \mathrm{~mm}$ screen) and self-fed at levels of $20,45,70$ and $95 \%$ of complete rations to a total of 192 crossbred steers ( 4 Charolais $\times$ Hereford and 4 Angus $x$ Hereford assigned to each ration) in each of the two replicates (years). Steers averaged $363 \mathrm{~kg}$ at the start of the test. Long hay was available initially to the cattle fed the high grain rations and oats was used as the grain portion of the ration, then gradually replaced with barley.

Various hays and straw (in some rations) were blended to provide a "good" hay (about 16\% CP), a "medium" hay $(11.5 \% \mathrm{CP})$ and a "poor" hay (9.8\% CP). All steers were implanted and self-fed. Rations were supplemented with minerals, vitamin $A$ and an antibiotic and carcasses individually assessed under the Blue Tag Program of the Production and Inspection Branch at Agriculture Canada. The results are summarized as follows (Table 30) to facilitate comparisons.

Table 30.

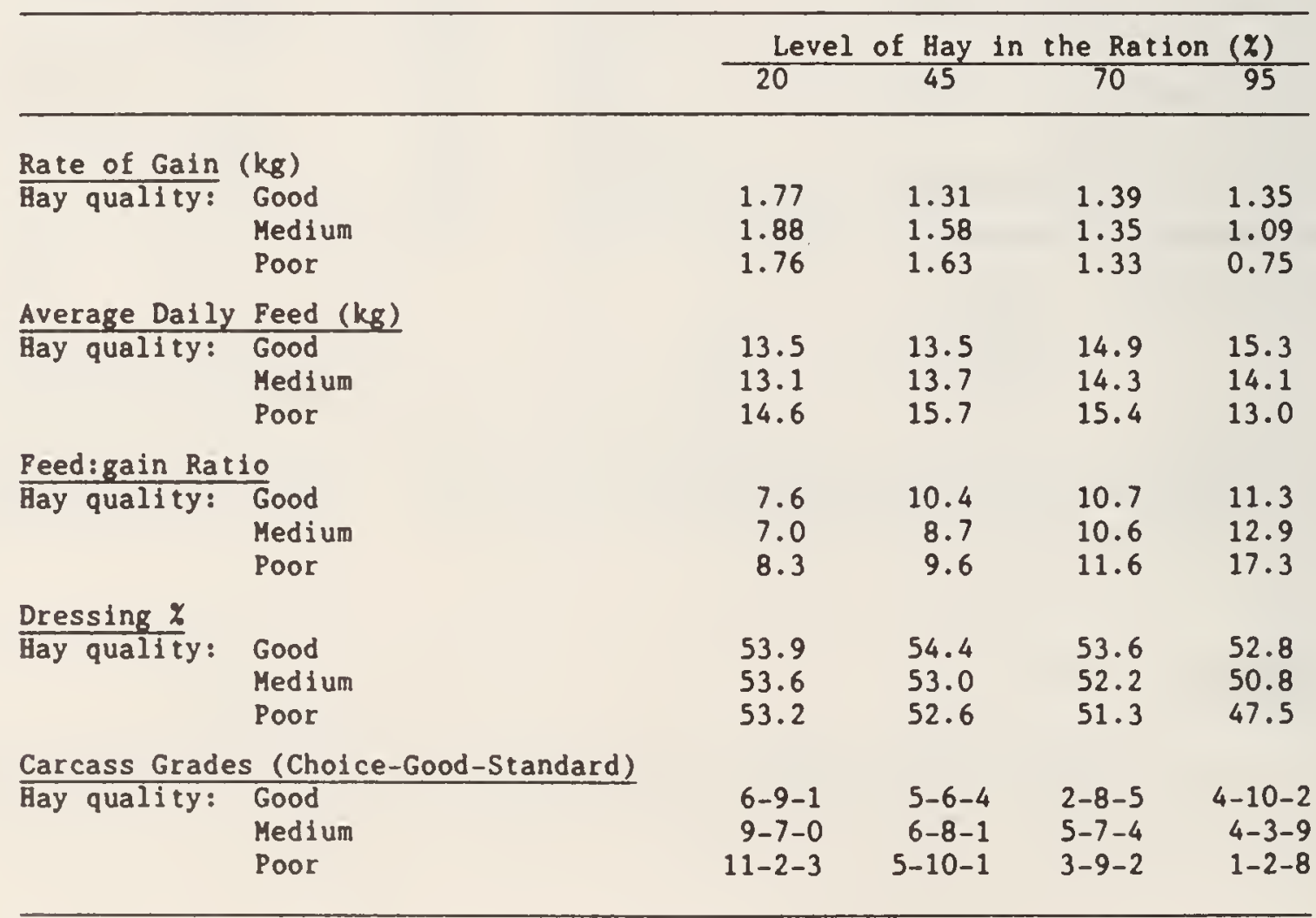


1. Rate of gain was adversely affected by increasing the level of ground hay in the ration, with the greatest depression occurring when the poor quality forage was fed. At the $45 \%$ hay level, rate of gain was improved as the quality of hay decreased, probably due to the occurrence of bloat when the good quality (largely alfalfa) hay was fed at this level. (In the first year, 3 steers fed the 45\% good hay ration bloated repeatedly, and in the second year, bloat occurred in steers fed the 45 and $70 \%$ levels of good hay, with one death occurring in each treatment.

2. Steers fed good quality hay increased their intake of feed as the level of hay in the ration increased, presumably in an effort to increase energy intake. Those fed medium quality hay increased intake to the $70 \%$ hay level, while those fed the poor quality hay, while eating more feed than those fed either the good or medium quality hay, maximized intake at the $45 \%$ hay level.

3. As the level of hay in the ration increased, feed efficiency, as expected, was reduced with those fed the good quality hay requiring 3.7 more units of feed per unit of gain as the level of hay increased from 20 to $95 \%$, while those fed the poor quality hay required an additional 9 units of feed per unit of gain when the hay level increased from 20 to $95 \%$.

4. As forage level increased, the dressing percentage of the steers fed the good quality hay fell from 53.9 on the $20 \%$ hay ration to 52.8 on the $95 \%$ hay ration, while the comparable drop for the steers fed the poor quality hay was from 53.2 to $47.5 \%$.

5. Carcass grades (under the grading system existing at the time) indicated that even at the high level of poor quality hay, it was possible for some steers to reach an acceptable degree of finish, although the trend in grades certainly indicates a decided reduction in grades as the level of medium and poor quality hay increased. With a subsequent change in the grading system to favor leaner carcasses, the effect on grades would not be so drastic today, nevertheless, the feeding of at least $30 \%$ grain with the medium quality hay and $50 \%$ grain with the poorer quality hay would appear to be required. In practice, the feeder would have to adjust the hay:grain level according to the performance of the cattle and the relative cost of hay and grain.

6. The project indicated the importance of high quality hay when constituting over $70 \%$ of the finishing ration. It also showed that hay quality was of minor importance when fed with grain at $20 \%$ of the ration. At the $45 \%$ hay level, good quality alfalfa is to be avoided and poorer quality hay, although reducing dressing percentage, supported a higher rate of gain and good carcass grades.

If the producer wishes to use ground, good quality alfalfa hay in cattle finishing rations, it is recommended that at the $30 \%$ grain level, the ration 
include $5 \%$ straw, in order to dilute the alfalfa and reduce the tendency to b] nat, and that the straw be increased to $20 \%$ at the $50 \%$ grain level. The plan for this feeding practice is illustrated in Figure 7.

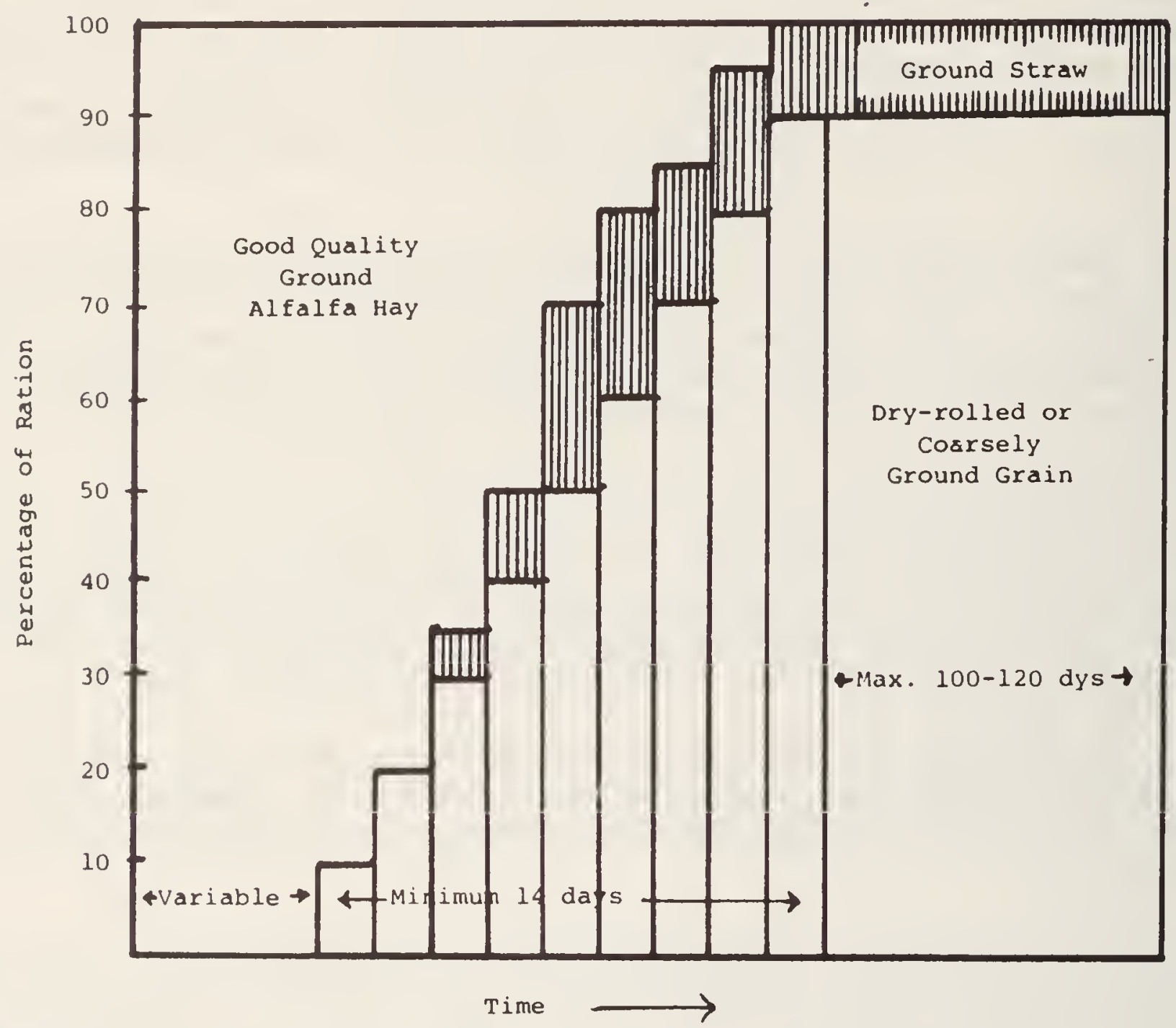

Fig. 7. Feeding plan when changing from ground, high quality alfalfa to high grain ration

\section{ADJUSTING FROM HIGH-FORAGE TO HIGH-GRAIN RATIONS FOR FINISHING STEERS}

While it has been demonstrated that very good rates of gain could be obtained by feeding good quality, ground hay at levels of up to 95 percent of the ration, it has also been found that, in general, feed costs were higher, dressing percentages and grades lower and that returns to labor tended to be lower as increasing levels of ground hay were included in steer finishing rations. Many factors will affect the economics of feeding high levels of ground hay, - the cost of grain vs hay, the availability of efficient feed processing equipment, the cost of fuel and the market value of the product. During the progress of our work on forage finishing of cattle, there was a marked shift in the carcass grading standards, favoring leaner beef. This, of course, favored the forage over the grain-fed animals, as the lower energy forage-based rations tended to allow the animal to grow to heavier weights 
before reaching the required degree of finish.

It was observed during our work, that forage-fed cattle got off to an excellent start when self-fed ground hay rations, with no setbacks due to overeating, as sometimes occur with grain-fed cattle. We also noted that both forage- and grain-fed cattle had a tendency to tire of their rations toward the end of the feeding period, and that grain-fed cattle, fed for long periods, tended to develop parakeratosis of the rumen lining, and absessed livers. Grain-fed cattle always had a higher dressing percentage than forage-fed cattle.

Because of this it was felt that we should study the effect of starting cattle out on high, ground-hay rations and gradually change to a high-grain ration over different time periods.

A feeding trial involving 48, $294 \mathrm{~kg}$ Charolais $\mathrm{x}$ Angus steers was carried out in each of two summers to evaluate four feeding systems as follows:

1. A $50 \%$ ground hay starter ration was fed for two days, with the amount of grain increased at two day intervals, so that by the 9 th day the cattle were at the $90 \%$ grain level.

2. Each lot (12 head) fed $909 \mathrm{~kg}$ lots of $70,60,50,40,30$ and $20 \%$ (half straw) ground hay rations in succession before receiving the $90 \%$ grain finishing ration.

3. As for Lot 2, except that $1818 \mathrm{~kg}$ of each ration was fed.

4. As for Lot 2, except that $2727 \mathrm{~kg}$ of each ration was fed.

All steers had access to cobalt-iodized block salt and water at all times, except that for the 12 hours prior to weighing (at weekly intervals) water bowls were covered. Grain was dry-rolled and roughage processed through a $13 \mathrm{~mm}$ screen. Implant treatments were evaluated within ration treatments, with 9 of the 12 steers on each ration treatment receiving implants.

All cattle were marketed directly to the plant after 155 days on feed, and carcasses evaluated under the Blue Tag Program of the Production and Inspection Branch of Agriculture Canada.

The ration formula are shown in Table 31 . 
Table 31. Ration formulae (\%)

\begin{tabular}{|c|c|c|c|c|c|c|c|c|}
\hline \multirow[b]{2}{*}{ Ingredient } & \multicolumn{8}{|c|}{ Roughage Level } \\
\hline & Starter & 70 & 60 & 50 & 40 & 30 & 20 & Finisher \\
\hline Brome-alfalfa hay & 50 & 70 & 60 & 50 & 40 & 30 & 10 & 0 \\
\hline Wheat straw & - & - & - & - & - & - & 10 & 10 \\
\hline Beet pulp & - & - & - & - & - & - & 10 & 10 \\
\hline Molasses & 4.65 & - & - & - & - & - & - & - \\
\hline Grain (rolled) & 25 & 28.3 & 38.4 & 48.4 & 58.4 & 68.4 & 78.4 & 88.4 \\
\hline $\begin{array}{l}\text { Calcium phosphate } \\
(18.5 \% \mathrm{Ca}, 20.5 \% \mathrm{P})\end{array}$ & 2.25 & 1.0 & 0.85 & 0.71 & 0.5 & 0.37 & 0.21 & - \\
\hline Limestone & - & - & 0.14 & 0.29 & 0.5 & 0.64 & 0.79 & 1.0 \\
\hline Cobalt-iodized salt & 0.4 & 0.5 & 0.5 & 0.5 & 0.5 & 0.5 & 0.5 & 0.5 \\
\hline $\begin{array}{l}\text { ADE supplement } \\
(10,000 \text { IU vit. } \\
\text { A/gm })\end{array}$ & 0.05 & 0.05 & 0.05 & 0.05 & 0.05 & 0.05 & 0.05 & 0.05 \\
\hline Aurofac 10 & 0.15 & 0.15 & 0.15 & 0.15 & 0.15 & 0.15 & 0.15 & 0.15 \\
\hline Crude protein \% & 13.2 & 14.9 & 14.7 & 14.4 & 14.1 & 13.9 & 12.2 & 12.0 \\
\hline Calculated TDN & 57 & 56 & 59 & 61 & 64 & 67 & 68 & 71 \\
\hline Density $\left(\mathrm{kg} / \mathrm{m}^{2}\right)$ & 312 & 276 & 284 & 300 & 334 & 365 & 401 & 457 \\
\hline
\end{tabular}

The performance of the steers is summarized in Table 32.

Table 32. Performance of steers fed increasing levels of ground hay ( $2 \mathrm{yr}$ average, 24 steers/ration - 155 day trial)

\begin{tabular}{|c|c|c|c|c|}
\hline & $\begin{array}{l}\text { Lot } \# 1 \\
\text { (Av. } \\
1 \% \text { hay) }\end{array}$ & $\begin{array}{l}\text { Lot } \# 2 \\
\text { (Av. } \\
11 \% \text { hay) }\end{array}$ & $\begin{array}{c}\text { Lot } \# 3 \\
\text { (Av. } \\
21 \% \text { hay) }\end{array}$ & $\begin{array}{l}\text { Lot \#4 } \\
\text { (Av. } \\
31 \% \text { hay) }\end{array}$ \\
\hline $\begin{array}{l}\text { Average final weight }(\mathrm{kg}) \\
\text { Average daily gain }(\mathrm{kg}) \\
\text { Average daily feed }(\mathrm{kg})\end{array}$ & $\begin{array}{r}519 \\
1.45 \\
11.0\end{array}$ & $\begin{array}{r}518 \\
1.45 \\
11.6\end{array}$ & $\begin{array}{r}520 \\
1.47 \\
12.0\end{array}$ & $\begin{array}{r}528 \\
1.52 \\
12.4\end{array}$ \\
\hline $\begin{array}{l}\text { Total feed/head }(\mathrm{kg}) \\
\text { - hay } \\
\text { - straw } \\
\text { - grain } \\
\text { - other }\end{array}$ & $\begin{array}{r}\frac{1701}{20} \\
167 \\
1480 \\
34\end{array}$ & $\begin{array}{r}\frac{1809}{198} \\
146 \\
1436 \\
29\end{array}$ & $\begin{array}{r}\frac{1855}{394} \\
113 \\
1320 \\
28\end{array}$ & $\begin{array}{r}1917 \\
597 \\
79 \\
1210 \\
31\end{array}$ \\
\hline $\begin{array}{l}\text { Feed:gain ratio } \\
\text { Average carcass weight }(\mathrm{kg}) \\
\text { Dressing \% } \\
\text { Carcass grades } \star \text { : A1, A2 }\end{array}$ & $\begin{array}{r}7.55 \\
293.6 \\
56.5 \\
19\end{array}$ & $\begin{array}{r}8.05 \\
292.2 \\
56.4 \\
20\end{array}$ & $\begin{array}{r}8.19 \\
292.3 \\
56.2 \\
19 \\
5\end{array}$ & $\begin{array}{r}8.22 \\
295.9 \\
56.1 \\
22\end{array}$ \\
\hline $\begin{array}{l}\text { Backfat }(\mathrm{mm}) \\
\text { Area of lean eye }\left(\mathrm{cm}^{2}\right)\end{array}$ & $\begin{array}{r}5 \\
19 \\
77\end{array}$ & $\begin{array}{r}4 \\
19 \\
77\end{array}$ & $\begin{array}{r}5 \\
18 \\
76\end{array}$ & $\begin{array}{r}2 \\
18 \\
77\end{array}$ \\
\hline
\end{tabular}

$\star \star$ Estimated from $1971-72$ grading system. 
The effect of using implants for steers within ration treatment is summarized in Table 33.

Table 33. A comparison of Ralgro and Synovex implants for steers

\begin{tabular}{lrrr}
\hline & Implant & Treatment & (av. 148 days) \\
\cline { 2 - 4 } & Control & Ralgro & Synovex S \\
\hline Average initial weight (kg) & 300 & 302 & 304 \\
Average final weight (kg) & 504 & 530 & 535 \\
Average daily gain (kg) & 1.38 & 1.54 & 1.56 \\
Carcass weight (kg) & 282 & 299 & 303 \\
Dressing \% & 55.9 & 56.5 & 56.6 \\
Depth of backfat (mm) & 21 & 20 & 19 \\
Area of eye of lean $\left(\mathrm{cm}^{2}\right)$ & 73 & 74 & 80 \\
\hline
\end{tabular}

Comments (Table 33)

1. Cattle in the test were considerably overfinished by today's standards.

2. Including progressively more ground forage in the ration, marginally increased rate of gain, increased intake of feed and increased feed:gain ratio. The increased rate of gain was offset by the reduction in dressing percentage as the amount of forage in the ration increased, with the result that carcass weights were essentially comparable.

3. Unless hay was valued at less than half the cost of grain, it is unlikely that it would be worth the effort to incorporate the rather minimal amounts of hay into the high grain rations used in this test.

4. Implanting with Ralgro and Synovex $\mathrm{S}$ increased rate of gain by 11.5 and $13 \%$, respectively, and resulted in increased carcass weights with marginally less backfat compared to the unimplanted steers.

\section{A COMPARISON OF SEVERAL RATES OF REDUCING THE LEVEL OF GROUND HAY IN STEER FINISHING RATIONS}

Because we had found no adverse effert due to including a fairly high (70\%) level of ground hay during the early stages of a steer finishing trial (average $30 \%$ hay over the feeding period) it was deemed important to determine how much hay could be included into a ration in which the grain component would increase to a high level during the last few weeks of the feeding period. 
Twelve crossbred steers were assigned to each of four ration treatments. steers were se]f-fed rations containing $50,70,80$ and 90 percent ground mixed grass hay initially, and over periods of time ranging from 9 days to 15, 16 and 18 weeks, gradually shifted onto a finishing ration containing 90 , 90,80 and $70 \%$ grain, respectively (Fig. 8).

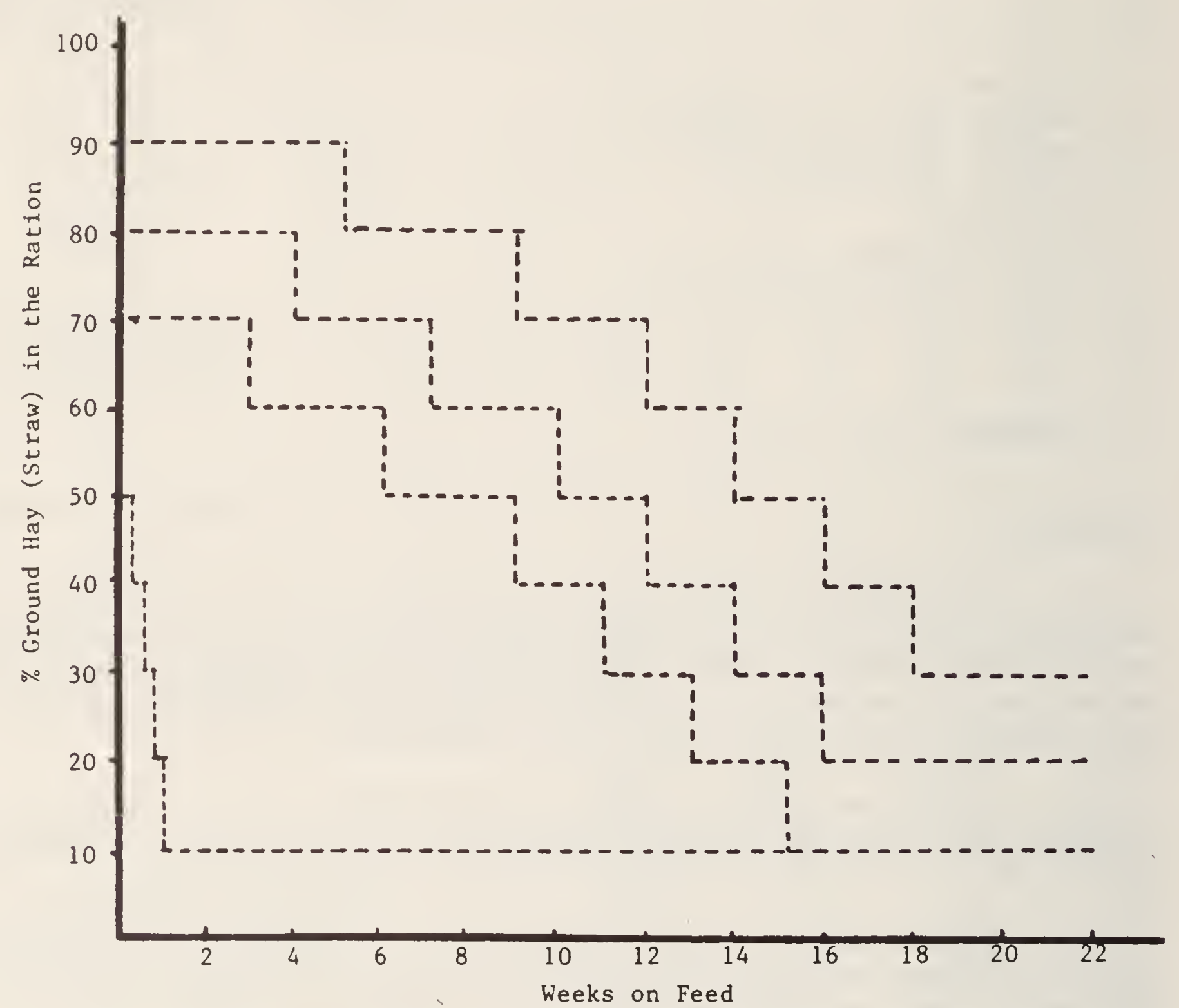

Fig. 8. Feeding plan.

The ration composition is shown in Table 34, animal performance is summarized in Table 35, and the effect of implant treatment (administered within ration treatments) or rate of gain and carcass characteristics is summarized in Table 36.

Four steers failed to complete the test, one in each lot. One injured a hip and three began to loss weight and did not respond to treatment. 
Table 34. Composition of steer finishing rations (\%)

\begin{tabular}{|c|c|c|c|c|c|c|c|c|c|c|}
\hline \multirow{2}{*}{$\begin{array}{l}\text { Ingredient } \\
\text { Ground grass hay }\end{array}$} & \multirow{2}{*}{$\begin{array}{r}\text { Starter } \\
50\end{array}$} & \multicolumn{8}{|c|}{ - Ground Hay Rations } & \multirow{2}{*}{$\begin{array}{r}\text { Finister } \\
0\end{array}$} \\
\hline & & 90 & 80 & 70 & 60 & 50 & 40 & 30 & 20 & \\
\hline Ground wheat straw & - & - & - & - & - & - & - & - & 10 & 10 \\
\hline Beet pulp & 17.5 & - & - & - & - & - & - & - & - & - \\
\hline Molasses & 4.65 & - & - & - & - & - & - & - & - & - \\
\hline Tallow or canola oil & - & 2.0 & 2.0 & 2.0 & 2.0 & 2.0 & 2.0 & 2.0 & 2.0 & 2.0 \\
\hline Rolled grain & 25.0 & 6.2 & 16.3 & 26.4 & 36.4 & 46.4 & 56.4 & 66.4 & 76.4 & 86.4 \\
\hline Calcium phosphate & 2.25 & 1.2 & 1.1 & 1.0 & 0.9 & 0.7 & 0.5 & 0.4 & 0.2 & - \\
\hline Limestone & - & - & - & - & 0.1 & 0.3 & 0.5 & 0.6 & 0.8 & 1.0 \\
\hline Salt & 0.4 & 0.5 & 0.5 & 0.5 & 0.5 & 0.5 & 0.5 & 0.5 & 0.5 & 0.5 \\
\hline Vitamin ADE supplement & 0.05 & 0.02 & 0.02 & 0.02 & 0.02 & 0.02 & 0.02 & 0.02 & 0.02 & 0.02 \\
\hline Aurofac 10 & 0.15 & 0.1 & 0.1 & 0.1 & 0.1 & 0.1 & 0.1 & 0.1 & 0.1 & 0.1 \\
\hline Crude protein $\%$ ( $90 \%$ DY basis) & 10.8 & 10.1 & 10.4 & 11.2 & 11.4 & 12.0 & 12.4 & 13.0 & 12.4 & 12.4 \\
\hline Density $\left(\mathrm{kg} / \mathrm{m}^{2}\right)$ & 245 & 187 & 212 & 226 & 259 & 273 & 307 & 340 & 340 & 412 \\
\hline
\end{tabular}

35. Performance of finishing steers started at different levels of ground hay ( 147 day test)

\begin{tabular}{|c|c|c|c|c|}
\hline & $\begin{array}{l}\text { Lot } 1 \\
90 \% \text { grain } \\
\text { at } 9 \text { days }\end{array}$ & $\begin{array}{l}\text { Lot } 2 \\
90 \% \\
\text { grain } \\
\text { at } 105 \\
\text { days }\end{array}$ & $\begin{array}{l}\text { Lot } 3 \\
80 \% \\
\text { grain } \\
\text { at } 119 \\
\text { days }\end{array}$ & $\begin{array}{l}\text { Lot } 4 \\
70 \% \\
\text { grain } \\
\text { at } 126 \\
\text { days }\end{array}$ \\
\hline $\begin{array}{l}\text { Average initial weight }(\mathrm{kg}) \\
\text { Average final weight }(\mathrm{kg}) \\
\text { Average daily gain }(\mathrm{kg}) \\
\text { Average daily feed }(\mathrm{kg}) \\
\text { Feed:gain ratio }\end{array}$ & $\begin{array}{r}347 \\
573 \\
1.53 \\
10.72 \\
6.99\end{array}$ & $\begin{array}{r}351 \\
580 \\
1.56 \\
12.33 \\
7.89\end{array}$ & $\begin{array}{r}348 \\
562 \\
1.45 \\
12.37 \\
8.50\end{array}$ & $\begin{array}{r}349 \\
553 \\
1.39 \\
12.26 \\
8.83\end{array}$ \\
\hline $\begin{array}{l}\text { Total feed/head }(\mathrm{kg}) \\
\text { - hay } \\
\text { - straw } \\
\text { - grain } \\
\text { - other }\end{array}$ & $\begin{array}{r}1579 \\
25 \\
153 \\
1340 \\
61\end{array}$ & $\begin{array}{r}1814 \\
600 \\
67 \\
1090 \\
57\end{array}$ & $\begin{array}{r}1820 \\
885 \\
35 \\
843 \\
57\end{array}$ & $\begin{array}{r}1805 \\
1175 \\
0 \\
573 \\
57\end{array}$ \\
\hline $\begin{array}{l}\text { Feed cost/head (\$) } \\
\text { Feed cost/kg gain ( }(c) \\
\text { Carcass weight (kg) } \\
\text { Dressing } \%\end{array}$ & $\begin{array}{r}198.75 \\
88 \\
323 \\
56.3\end{array}$ & $\begin{array}{r}205.87 \\
90 \\
324 \\
55.8\end{array}$ & $\begin{array}{r}193.63 \\
90 \\
316 \\
56.1\end{array}$ & $\begin{array}{r}178.31 \\
87 \\
313 \\
56.5\end{array}$ \\
\hline $\begin{array}{ll}\text { Carcass grades: } & \mathrm{A} 1, \mathrm{~A} 2 \\
& \mathrm{~A} 3\end{array}$ & $\begin{array}{r}10 \\
1\end{array}$ & $\begin{array}{r}10 \\
1\end{array}$ & $\begin{array}{r}10 \\
1\end{array}$ & $\begin{array}{r}10 \\
1\end{array}$ \\
\hline $\begin{array}{l}\text { Average carcass value }(\$) \\
\text { Carcass value less feeder and feed }\end{array}$ & 1024.79 & 1030.32 & 1004.88 & 995.34 \\
\hline $\begin{array}{l}\cos t(\$) \\
\text { Less other costs (interest, }\end{array}$ & 184.09 & 175.10 & 167.45 & 171.38 \\
\hline $\begin{array}{l}\text { yardage, veterinary, implant and } \\
\text { shipping ( } \$ / \text { head) }\end{array}$ & 72.90 & 73.20 & 72.98 & 73.05 \\
\hline $\begin{array}{l}\text { Return to labor, feed processing } \\
\text { and capital cost ( } \$ / \text { head) }\end{array}$ & 111.19 & 101.90 & 94.47 & 98.33 \\
\hline
\end{tabular}


Table 36. Effect of implant treatment on performance of feedlot steers (averaged across rations)

\section{Control Ralgro Synovex S}

Number of steers

16

349

548

1.37

309

55.5

Dressing \%

Carcass grades: $\mathrm{A} 1, \mathrm{~A} 2$

A3
15

1
15

349

578

1.56

330

56.2

13

2
13

354

581

1.54

329

56.7

12

Table 37. Effect of ration $x$ implant interaction on rate of gain

\begin{tabular}{lccccc}
\hline & \multicolumn{5}{c}{ Hay Level } \\
\cline { 2 - 5 } & $\begin{array}{l}\text { Low } \\
(11 \%)\end{array}$ & $\begin{array}{c}\text { Medium } \\
(37 \%)\end{array}$ & $\begin{array}{c}\text { Moderate } \\
(51 \%)\end{array}$ & $\begin{array}{c}\text { High } \\
(65 \%)\end{array}$ & Average \\
\hline $\begin{array}{l}\text { Control } \\
\text { Ralgro }\end{array}$ & 1.48 & 1.51 & 1.30 & 1.21 & 1.37 \\
Synovex & 1.59 & 1.65 & 1.51 & 1.47 & 1.55 \\
$\quad$ Average & 1.54 & $\underline{1.52}$ & $\underline{1.57}$ & $\underline{1.52}$ & 1.54 \\
\hline
\end{tabular}

Comments (Tables 35, 36 and 37)

1. Returns to labor, processing and capital costs were about $\$ 13 /$ head less for the steers fed the high forage ration.

2. Rates of gain were quite good on all rations with quite acceptable feed:gain ratios, considering the TDN content of the rations. Dressing percentages and carcass grades were not adversely affected by feeding the highest level of ground hay.

3. Both implant treatments increased rate of gain (average $13 \%$ ), dressing percentage and carcass weights, with response to implantation being much higher for steers fed the rations with the higher levels of ground hay (average $0.27 \mathrm{~kg}$ for steers fed the moderate and high levels of hay vs 0.8 $\mathrm{kg} /$ day for steers fed the low and medium levels of hay). 


\section{ADDING ACIDULATED FATTY ACIDS (AFA) TO A GROUND, GOOD QUALITY HAY RATION FOR FINISHING STEERS}

Ground, good quality hay rations tend to be dusty and to contain a higher proportion of protein to energy than is optimal for growing-finishing steers. The availability of a low viscosity (compared to tallow) high energy by-product of the manufacture of canola oil, called acidulated fatty acids (AFA), at a reasonable price (range $22-44 \mathrm{c} / \mathrm{kg}$ ) appeared to offer promise as a supplement that would not only eliminate dust but would bring the energy level of a high forage ration into better balance with its protein content. AFA contains oleic ( $58 \%)$, linoleic $(28 \%)$, linolenic $(8 \%)$, and palmitic $(5 \%)$ fatty acids plus small and variable amounts of salt, phosphoric and sulphuric acids, phosphatides (gums), water and canola oil. (Estimated TDN value, 180-200\%.) It has a $\mathrm{pH}$ of 7 (non-corrosive) and does not build up inside mixing equipment as tallow does. The rations fed were formulated as follows.

\begin{tabular}{|c|c|c|c|}
\hline & \multicolumn{3}{|c|}{ Ration No. } \\
\hline & $\begin{array}{c}1 \\
\text { Check }\end{array}$ & $\begin{array}{ll}2 \\
4 \% & \text { AFA }\end{array}$ & $\begin{array}{ll}3 & 3 \\
& \text { AFA }\end{array}$ \\
\hline Ground alfalfa hay $(1.27 \mathrm{~cm}$ screen $)$ & 982.4 & 942.4 & 932.4 \\
\hline AFA & - & 40 & 50 \\
\hline Cobalt-iodized, trace-mineralized salt & 5 & 5 & 5 \\
\hline Calcium phosphate $(18 \% \mathrm{Ca}, 20.5 \% \mathrm{P})$ & 12 & 12 & 12 \\
\hline Vitamin $\operatorname{ADE}(10,000 \mathrm{IU}$, vit. $\mathrm{A} / \mathrm{gm})$ & 0.2 & 0.2 & 0.2 \\
\hline Aurofac $10(22 \mathrm{gm} / \mathrm{kg})$ & 0.4 & 0.4 & 0.4 \\
\hline Total & $\overline{1000.0}$ & $\overline{1000.0}$ & $\overline{1000.0}$ \\
\hline Dry matter \% & 88.5 & 87.2 & 88.4 \\
\hline Crude protein (\% of DM) & 14.5 & 15.1 & 15.6 \\
\hline Dig. organic matter ( $\%$ of $D M)$ & 56.0 & 54.2 & 55.6 \\
\hline Estimated TDN & 56.0 & 61.7 & 63.1 \\
\hline
\end{tabular}

The results of the feeding trial are summarized in Table 38. 
Table 38. The effect of supplementing ground brome-alfalfa hay rations with AFA on the performance of $380 \mathrm{~kg}$ finishing beef steers

\section{Control $\quad 4 \%$ AFA* $5 \%$ AFA}

Av. final weight $(\mathrm{kg})$

Days on feed

Av. daily gain $(\mathrm{kg})$

Feed:gain ratio

Feed cost/head $(\$)$

Processing @ $\$ 7.15 /$ tonne $(\$)$

other (facilities, interest, implant,

veterinary, \& shipping) (\$)

Carcass wt. (kg)

Dressing \%

Grades, A1, A2

Backfat cover $(\mathrm{mm})$

Carcass value $(\$)$

Initial value of feeder ( $\$$ )

Total production costs (\$)

Av. return/hd (\$)

$\begin{array}{rrr}536 & 549 & 530 \\ 109 & 102 & 99 \\ 1.42 & 1.65 & 1.50 \\ 9.31 & 8.41 & 9.43 \\ 109.16 & 122.61 & 126.42 \\ 10.37 & 10.06 & 10.05 \\ & & \\ 52.34 & 49.50 & 48.97 \\ 284.5 & 293.6 & 290.9 \\ 53.1 & 53.6 & 54.9 \\ 10 & 10 & 10 \\ 11.4 & 9.4 & 10.6 \\ 913.25 & 942.46 & 933.79 \\ 703.00 & 704.85 & 704.85 \\ 171.87 & 182.17 & 185.44 \\ 38.38 & 55.44 & 43.50\end{array}$

ॠAFA valued at $36.3 \mathrm{c} / \mathrm{kg}$.

Comments (Table 38)

1. The use of acidulated fatty acids at the $4 \%$ level improved rate of gain by $16 \%$, feed efficiency by $9.7 \%$, dressing $\%$ by 0.5 percentage units and increased returns to labor by $\$ 17.06 /$ head.

2. AFA, where available within a reasonable distance at a reasonable price, is an excellent supplement for ground, high protein forage-based rations. In this test, the break-even price of the AFA would have been $42.3 \mathrm{c} / \mathrm{kg}$. Transportation and handling costs would also have to be considered when determining the economics of AFA use.

\section{EFFECT OF FEED ADDITIVES, HIGH ENERGY SUPPLEMENTS AND PELLETING ON THE PERFORMANCE OF FINISHING STEERS}

A feeding trial was carried out with 128 yearling crossbred steers to investigate a number of factors which might affect the response of finishing steers fed rations based on ground, good quality hay. A high-grain control ration was included to permit a practical assessment of results. All rations were prepared with a Bearcat grinder-mixer and pelleting done with the station's pelleting equipment. Rations to be pelleted were ground through a $0.6 \mathrm{~mm}$ screen, while the roughage components of the rations fed in the ground 
form were processed through a $1.27 \mathrm{~cm}$ screen. All rations were self-fed from the start, with a series of low to moderate energy starter rations used to get the steers fed the grain-based rations safely onto feed by the 9 th day. Aureomycin was fed to supply $100 \mathrm{mg} / \mathrm{head} /$ day and Rumensin at the recommended level ( $11 \mathrm{~g} /$ tonne of D.M. for 28 days, then $33 \mathrm{~g} /$ tonne). All steers had free access to cobalt-iodized block salt and a mineral mix (1 part cobalt-iodized trace mineralized, hi-iodine salt and 2 parts of a calcium phosphorus mineral supplement containing $18 \%$ calcium and $20.5 \%$ phosphorus). Steers were marketed when they were deemed to carry enough finish to qualify for A1 or A2 grades.

The results are presented in Table 39.

\section{Comments (Table 39)}

1. Adding $3 \%$ of acidulated fatty acids (AFA) to the high grain ration increased rate of gain by $5 \%$ and feed efficiency by $9.6 \%$, with no effect on carcass yield or grade, increasing returns by $\$ 13.50 /$ head.

2. Adding AFA to the ground hay + aureomycin ration had no effect on rate of gain, improved feed efficiency by $4 \%$, increased dressing percentage by 1.2 units and increased returns by $\$ 12.50$.

3. Replacing aureomycin with rumensin in the forage ration reduced rate of gain by $8 \%$, improved feed efficiency by $2 \%$, reduced dressing percentage by 0.8 units and reduced returns per steer by $\$ 20$. Replacing aureomycin with rumensin in the ground forage + AFA ration reduced rate of gain by $2 \%$, improved feed efficiency by $4 \%$, reduced dressing percentage by 0.5 units and reduced returns by $\$ 3.57$.

4. Adding tallow to the forage + aureomycin ration increased rate of gain by $6.4 \%$, and feed efficiency by $11 \%$, but the cost of the tallow $(66 \mathrm{k} / \mathrm{kg})$ nearly offset this to return only $\$ 2$ more per head. Returns on the steers receiving tallow were $\$ 10.60$ per head less than those receiving the AFA. Had the tallow been priced the same as the AFA, it's use would have returned about $\$ 5$ more per head than the AFA.

5. Pelleting the forage + aureomycin ration (approximately $6 \mathrm{~mm}$ die) led to the loss of two steers by bloat in the first replicate (fed good quality alfalfa) and likely caused digestive problems with some of the other animals, leading to poorer than expected rate of gain and feed efficiency, in view of the high level of intake.

6. Best forage ration was the one supplemented with aureomycin and $3 \%$ $A F A$, which returned about $\$ 1 /$ head less than the grain ration without AFA.

7. In this test Simmental $x$ Hereford steers gained faster than the Angus crossbreds and produced heavier carcasses with higher cutability, higher marbling score and greater dollar value. 


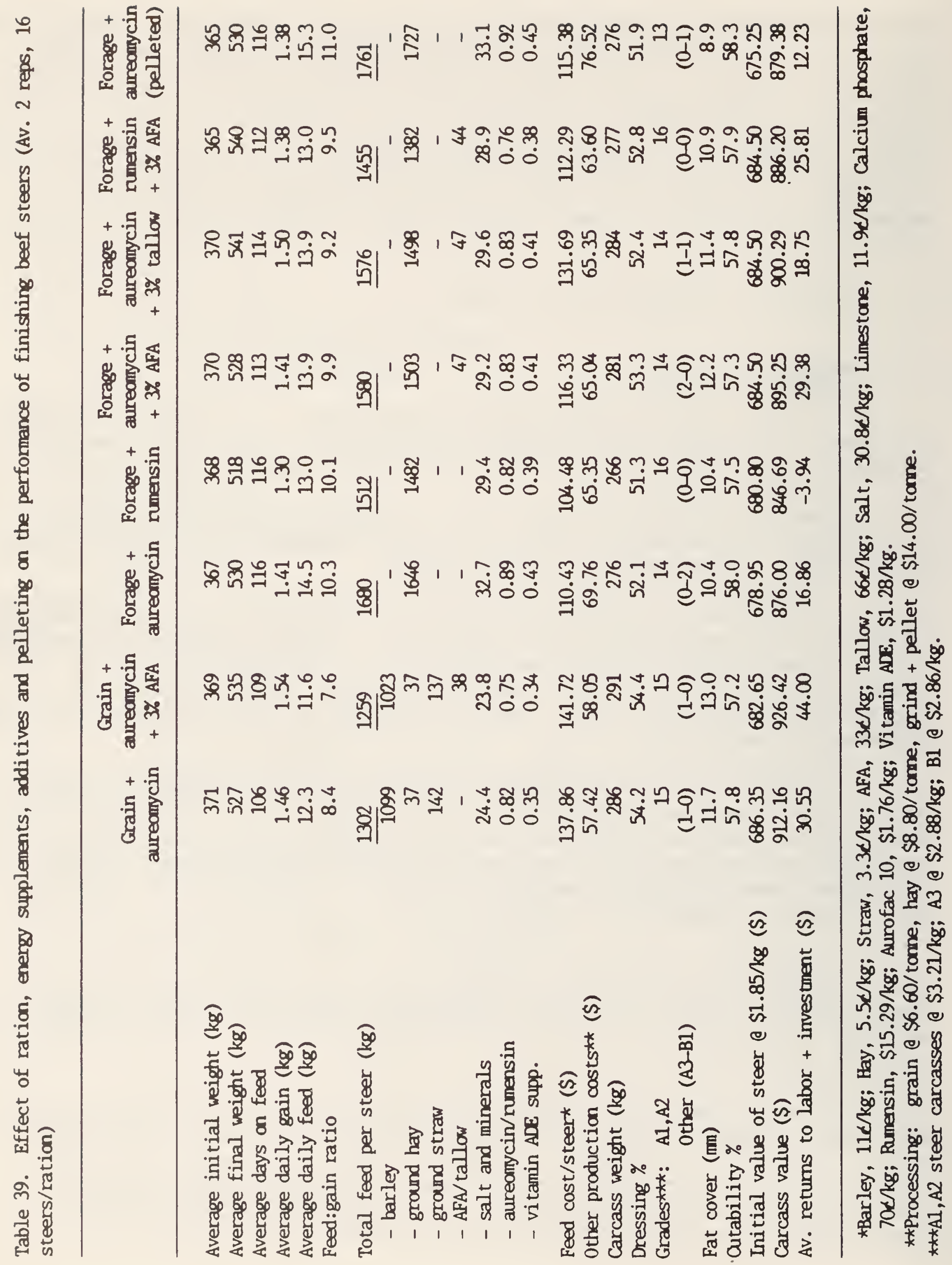


In the first year of this trial, alfalfa hay was used, while in the second year a brome-alfalfa hay was fed. The crude protein (C.P.) and digestible organic matter (D.O.M.) content of the eight rations are shown for each of the two years (Replicates).

\begin{tabular}{|c|c|c|c|c|c|c|}
\hline \multirow{3}{*}{ - } & \multicolumn{3}{|c|}{$\begin{array}{r}\text { Year } 1 \\
\text { Alfalfa } \\
\end{array}$} & \multicolumn{3}{|c|}{$\begin{array}{c}\text { Year } 2 \\
\text { Brome-alfalfa }\end{array}$} \\
\hline & \multirow[b]{2}{*}{$\mathrm{CP} \%$} & DOM & $\begin{array}{l}\text { Est. } \\
\text { TDN* }\end{array}$ & & DOM & $\begin{array}{l}\overline{\text { Est }} \\
\text { TDN }\end{array}$ \\
\hline & & $\%$ & $\%$ & $\mathrm{CP} \%$ & $\%$ & $\%$ \\
\hline Grain + aureomycin & 12.6 & 63.7 & 63.7 & 12.7 & 62.7 & 62.7 \\
\hline Grain + AFA + aureomycin & 12.5 & 63.5 & 67.7 & 12.4 & 63.2 & 67.3 \\
\hline Ground hay + aureomycin & 18.0 & 58.0 & 58.0 & 14.3 & 57.8 & 57.8 \\
\hline Ground hay + rumensin & 17.4 & 57.1 & 57.1 & 14.2 & 57.0 & 57.0 \\
\hline Ground hay + AFA + aureomycin & 17.2 & 56.5 & 60.6 & 13.8 & 56.0 & 60.3 \\
\hline Ground hay + tallow + aureomycin & 17.1 & 55.2 & 59.4 & 13.9 & 56.0 & 60.3 \\
\hline Ground hay + AFA + rumensin & 16.9 & 58.4 & 62.5 & 14.1 & 56.3 & 60.6 \\
\hline Pelleted hay + aureomycin & 15.8 & 57.9 & 57.9 & 15.2 & 57.4 & 57.4 \\
\hline
\end{tabular}

*Assuming AFA and tallow at $200 \%$ TDN.

\section{PELLETING HIGH FORAGE RATIONS}

In previous feeding trials it was found that cattle fed pelleted, high-quality alfalfa rations had a tendency to bloat. A small trial was carried out to compare three rations, based on ground alfalfa hay ( $95 \%)$, pelleted hay and pelleted hay plus rumensin. The results are summarized in Table 40. 
Table 40. The effect of pelleting and of rumensin on the utilization of alfalfa hay $(10,381 \mathrm{~kg}$ steers per ration*)

\begin{tabular}{lrrr}
\hline & $\begin{array}{c}\text { Ground } \\
\text { alfalfa } \\
\text { hay }\end{array}$ & $\begin{array}{c}\text { Pelleted } \\
\text { alfalfa } \\
\text { hay }\end{array}$ & $\begin{array}{c}\text { Pelleted } \\
\text { hay }+ \\
\text { rumensin }\end{array}$ \\
\hline Av. final weight (kg) & 545 & 529 & 535 \\
Days on feed & 108 & 104 & 100 \\
Av. daily gain (kg) & 1.52 & 1.43 & 1.53 \\
Feed:gain ratio & 8.75 & 9.30 & 8.71 \\
Hot carcass weight (kg) & 287 & 292 & 292 \\
Dressing \% & 52.7 & 55.1 & 54.7 \\
Av. backfat thickness (mm) & 11 & 11 & 9 \\
Av. return/head (\$) & -1.47 & 17.81 & 30.34 \\
Acetic:propionic ratio in rumen fluid & 4.3 & 3.8 & 3.4 \\
\hline
\end{tabular}

$\star$ Dry matter $89.2 \%$; crude protein $17.5 \%$; digestible organic matter 57.5 ; and ash $8.4 \%$.

\section{Comments (Table 40)}

1. Rate of gain and feed efficiency of the steers fed the pelleted hay ration were lower than for steers fed the ground ration. However, despite some bloat problems, the steers fed the pelleted ration dressed out heavier, graded better and returned about $\$ 19 /$ hd more than those fed the ground hay ration.

2. Adding rumensin to the pelleted alfalfa ration eliminated the bloat problem and produced a rate of gain and feed efficiency similar to that of the ground alfalfa-fed steers. A higher dressing percentage and better grades resulted in a return of about $\$ 32 /$ head more than the ground alfalfa-fed steers.

3. A pelleted alfalfa ration can cause bloat. Adding rumensin will eliminate bloat, due presumably to a reduction in gas production.

\section{PINISHING STEERS ON A VARIETY OF FORAGE BASED RATIONS}

An experiment was conducted in 1987 to obtain additional or new information on the performance of finishing beef steers and heifers fed rations based on crested wheatgrass hay or silage and on alfalfa. The effect of adding peas to a finishing ration based on crested wheatgrass silage followed by a barley ration was also determined.

The test involved 239 Charolais-sired, three-way cross yearlings (118 
steers and 121 heifers). All animals were implanted. In those treatments involving a growing ration followed by a finishing ration, the growing ration was fed for 60 days. Animals were either full-fed or self-fed, weighed at weekly intervals and, once approaching finished condition, were

ultrasonically measured to determine backfat thickness. All carcasses were evaluated under the Blue Tag program of the Production and Inspection Branch of Agriculture Canada.

The ration composition is shown in Table 41, and the animal performance summarized in Table 42.

Table 41. Ration composition \%

\begin{tabular}{|c|c|c|c|c|c|c|c|}
\hline & Grain & $\begin{array}{l}\text { Grain } \\
+ \text { peas }\end{array}$ & $\begin{array}{l}\text { Crested } \\
\text { wheat }\end{array}$ & $\begin{array}{c}\text { Crested } \\
\text { wheat } \\
+ \text { AFA }\end{array}$ & $\begin{array}{c}\text { Alfalfa } \\
+ \text { AFA }\end{array}$ & $\begin{array}{c}\underset{C W}{ } \\
\text { silage* }\end{array}$ & $\begin{array}{c}\text { CAG } \\
\text { silage } \\
+ \text { peas* }\end{array}$ \\
\hline Rolled barley & 85.37 & 78.37 & - & - & - & - & - \\
\hline Ground barley straw & 10.0 & 9.0 & - & - & - & - & - \\
\hline Peas & - & 8.0 & - & - & - & - & 8.0 \\
\hline Hay or silage & - & - & 98.3 & 94.3 & 94.3 & 100.0 & 92.0 \\
\hline Acidulated fatty acids & 3.0 & 3.0 & - & 4.0 & 4.0 & - & - \\
\hline Limestane & 0.6 & 0.6 & - & - & - & - & - \\
\hline Calcium phosphate & 0.5 & 0.5 & 1.2 & 1.2 & 1.2 & - & - \\
\hline Salt (cobalt-iodized trace mineralzed) & 0.5 & 0.5 & 0.5 & 0.5 & 0.5 & - & - \\
\hline Dry vitamin (ADE) & 0.025 & 0.025 & 0.02 & 0.02 & 0.02 & - & - \\
\hline Aurofac 50 & 0.02 & 0.02 & 0.02 & 0.02 & 0.02 & - & - \\
\hline \multicolumn{8}{|l|}{ Chemical Analysis (\% of Dry Matter) } \\
\hline Dry matter & 88.6 & 91.2 & 89.5 & 89.9 & 88.6 & 37.8 & 42.0 \\
\hline Crude protein & 11.0 & 11.6 & 11.0 & 10.4 & 18.2 & 14.2 & 15.0 \\
\hline Digestible organic matter & 71.4 & 73.4 & 64.9 & 62.6 & 63.0 & 66.9 & 68.6 \\
\hline
\end{tabular}

$\star$ Free choice minerals, vitamins and antibiotic sprinkled over silage daily. 


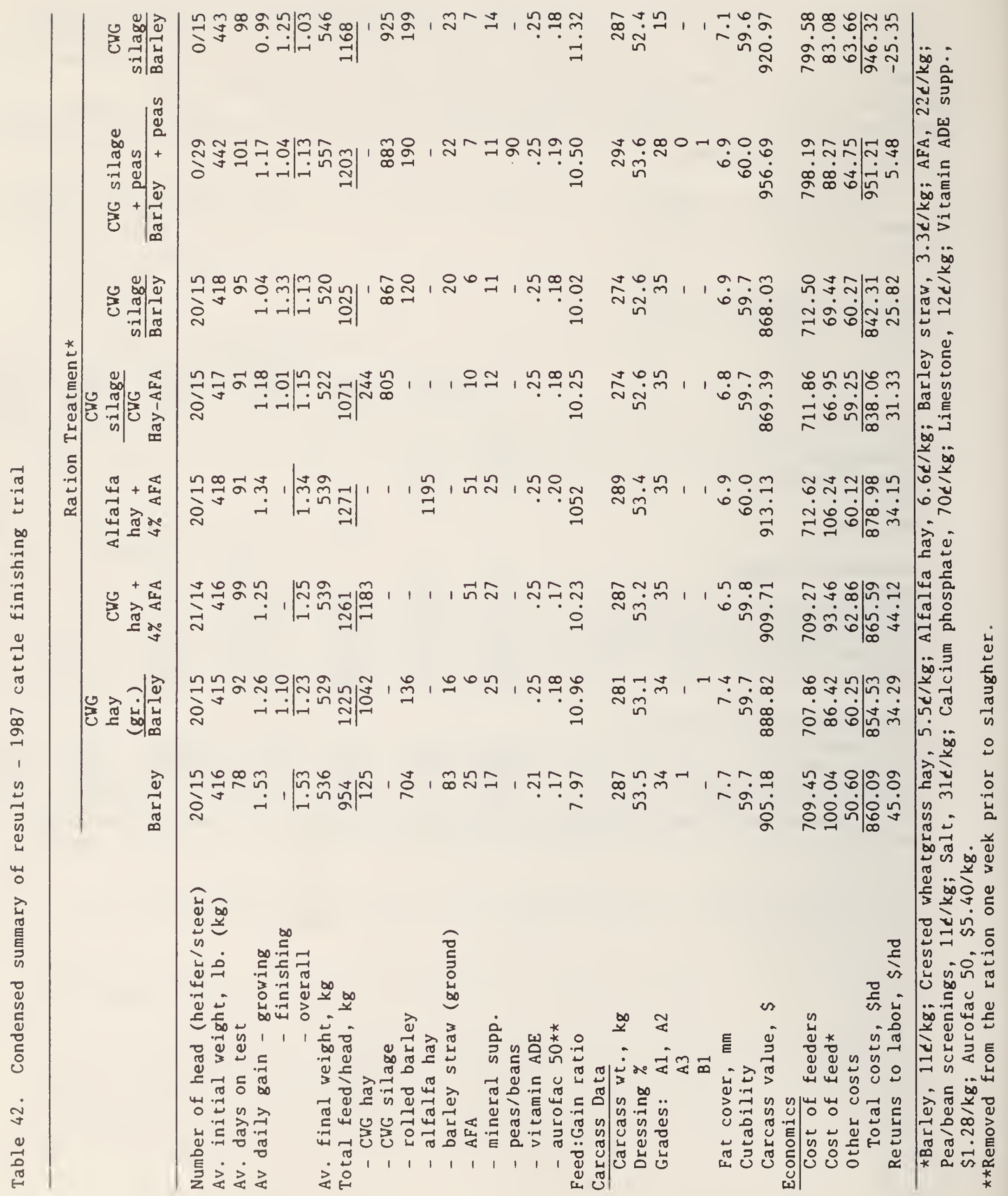




\section{Comments}

1. The use of ultrasonic measurements of backfat thickness markedly increased the number of carcasses grading A1 or A2 compared to most previous trials.

2. All cattle fed the ground hay or silage + AFA-based rations graded $\mathrm{A} 1$ or $\mathrm{A} 2$.

3. Returns to labor were almost as high, $\$ 44.12$ vs $\$ 45.09$, for the cattle fed the crested wheatgrass + AFA ration as for those fed the barley-based ration.

4. Despite lower crude protein content, crested wheat-AFA ration produced a better feed:gain ratio than did the alfalfa-AFA ration.

5. Rate of gain on crested wheatgrass silage was lower than on crested whea tgrass hay.

6. Supplementing the steer rations with pulse crop screenings improved the rate of gain when the CWG silage ration was fed but reduced it when the barley ration was fed. Combining the two feeding periods, favored the addition of the legume screenings and increased returns per steer by about $\$ 30$, largely because of improved dressing percentage and feed conversion efficiency.

\section{PARTIALLY REPLACING GROUND ALFALFA HAY WITH STRAW OR AMMONIATED STRAV IN A FINISHING RATION FOR STEERS AND HEIFERS}

Ammoniating cereal straw ( $3 \%$ anhydrous ammonia by weight) increases the crude protein and total digestible nutrient content and increases intake. Because of the abundance of cereal straw in the prairie provinces, its use in beef cattle rations is very logical, particularly as the main roughage source in beef cow wintering rations and as a diluent in high energy finishing rations. To determine the effect of replacing some of the ground, high quality hay in a finishing ration for steers and heifers, a project was undertaken, involving seventy-two head of Charolais-sired crossbred cattle, self-fed the following rations, (1) ground alfalfa (93\%) control, (2) control containing $25 \%$ ground barley straw, (3) control containing $25 \%$ ammoniated barley straw ( $3 \%$ anhydrous ammonia by weight), (4) control containing $35 \%$ ammoniated barley straw. The barley straw analysed $4 \%$ crude protein, $42 \%$ digestible organic matter and $20 \%$ moisture and was ground $(1.27 \mathrm{~cm}$ screen) before being ammoniated in an insulated plywood bin.

Shortage of space precludes presentation of detailed results. However none of the straw treatments had any merit, all resulting in poorer animal performance and a marked reduction in returns to labor $(\$ 35,-\$ 14,-\$ 25$ and -\$52 per head for the steers and heifers fed the control, $25 \%$ ground hay, $25 \%$ ammoniated straw and 35\% ammoniated straw treatments, respectively. 
Ammoniated cereal straw may have some merit when fed in other types of rations (cow wintering rations, perhaps at higher levels (to permit the development of a more suitable rumen microflora), or when the price or availability of good quality hay presents a problem. We might add that perhaps, if hay is available at a reasonable cost, cereal straw would be more useful if returned to build up the organic matter of the soil!

\section{IMPLANTS AND ADDITIVES FOR BEEF CATTLE FED FORAGE- AND GRAIN-BASED RATIONS}

Current feedlot technology includes the use of growth promoting implants and the use of additives to improve efficiency of digestion in the rumen or to counter low-level infections.

Growth promoting implants such as Synovex S (progesterone + estradiol), Synovex H (testosterone + estradiol). Ralgro (resorcyclic acid lactone) and Compudose (estradiol-17 beta) are hormone, or hormone-like products, which increase growth rate and feed efficiency and allow finishing cattle to be carried to heavier weights than non-implanted cattle of similar type, before reaching a comparable backfat thickness. The implant is placed under the hide at the mid point of the back of the ear. There is no withdrawal period for the Synovex or Compudose products, but Ralgro-implanted cattle must not be marketed prior to 65 days following implanting.

Feed additives include antibiotics such as aureomycin, terraymcin and penicillin and ionophores such as monensin and lasalocid.

The antibiotics administered at sub-therapeutic levels via the feed have been used in rations for growing poultry, swine and beef cattle, since they were dicovered in the late 1940's. These products counter low-level infections and generally result in healthier and faster-gaining animals and more efficient feed utilization. While the beneficial effect is most dramatic with "poor-doing" livestock suffering from stress or exposure to disease, the use of antibiotics in feed for normal livestock is usually cost effective.

In 1977 a new additive, Rumensin (monensin sodium) became available for use in beef cattle rations. The chemical (classed as an ionophore) has been used to control coccidiosis in poultry and was later found to have a beneficial effect on the fermentation process in the rumen. It increases the proportion of propionic acid relative to acetic and butyric acids, and because propionic acid is more efficiently utilized than acetic acid by the animal, the efficiency of feed utilization is improved. (There is less carbon dioxide and methane gas production which can, in some instances, reduce the incidence of bloat.)

It is claimed that Rumensin has no effect on the intake of forage-fed animals, but greater efficiency of feed utilization results in increased rate of gain. With grain-fed cattle, the greater production of propionic acid triggers the energy intake control mechanisms in the brain sooner, resulting 
in a decrease in feed intake, but because of the improved efficiency of feed utilization, the rate of gain is not altered.

Because of our interest in improving forage utilization by ruminants, it was decided to conduct a large-scale project to investigate the interactions of rations (forage vs grain), gender (steers vs heifers), implant (control, Synovex and Ralgro) and additive (aureomycin vs rumensin) on feedlot performance, carcass characteristics and the economics of beef production using Charolais-sired crossbreds (out of Angus $x$ Hereford and Simmental $x$ Hereford cows).

A replicated experiment involving 360 yearling steers and heifers was carried out. Two rations, one based on ground ( $1.27 \mathrm{~cm}$ screen) alfalfa hay, the other on dry rolled barley; two additives, aureomycin (fed to provide 110 $\mathrm{mg} / \mathrm{hd} / \mathrm{day}$ ) and rumensin (11 gm/tonne of dry matter for 28 days, then 33 $\mathrm{gm} /$ tonne DM); three implant treatments, check, Synovex S (200 mg progesterone plus $20 \mathrm{mg}$ estradiol benzoate) for steers, Synovex H (200 mg testosterone plus $20 \mathrm{mg}$ estradiol benzoate) for heifers and ralgro (24 $\mathrm{mg}$ resorcyclic acid lactone) used on steers only, were evaluated.

All rations were prepared with a farm-type grinder mixer, with hay and straw ground through a $1.27 \mathrm{~cm}$ screen. Rations were self-fed, with the grain-fed cattle receiving a series of starter rations to permit an adjustment of rumen microflora to the high-energy ration. Cattle had free access to salt, mineral mix and water. Carcass data were obtained under the Blue Tag Program of the Production and Inspection Branch of Agriculture Canada. A number of variable costs were deducted from the carcass value of the cattle to arrive at a relative return to labor and investment. The rations fed (except starter rations for grain-fed cattle) were formulated (\%) as follows:

\begin{tabular}{|c|c|c|}
\hline & $\begin{array}{l}\text { Forage } \\
\text { Ration }\end{array}$ & $\begin{array}{r}\text { Grain } \\
\text { Ration }\end{array}$ \\
\hline $\begin{array}{l}\text { Ground ( } 1.27 \mathrm{~cm} \text { ) alfalfa hay } \\
\text { Rolled barley } \\
\text { Barley straw (ground) } \\
\text { Acidulated fatty acids (from canola) (AFA) } \\
\text { Cobalt-iodized, trace mineralized salt } \\
\text { Calcium phosphate ( } 18 \% \mathrm{Ca}, 10.5 \% \mathrm{P}_{2} \mathrm{O}_{5} \text { ) } \\
\text { Limestone } \\
\text { Dry vitamin ADE ( } 10,000 \mathrm{IU} \mathrm{Vit} . \mathrm{A} / \mathrm{gm} \text { ) } \\
\text { Aureomycin* (Rumensin)** premix } \\
\text { Dry matter (\%) } \\
\text { Crude protein (DM basis) (\%) } \\
\text { Digestible organic matter (DM basis) (\%) } \\
\text { Ash (DM basis) ( } \% \text { ) }\end{array}$ & $\begin{array}{c}94.2 \\
- \\
- \\
4.0 \\
0.5 \\
1.2 \\
- \\
0.02 \\
.08(.075) \\
89.8 \\
16.3 \\
58 \\
10.5\end{array}$ & $\begin{array}{c}88.3 \\
10.0 \\
- \\
0.5 \\
0.5 \\
0.6 \\
0.025 \\
.08(.075) \\
87.9 \\
11.8 \\
65 \\
5.2\end{array}$ \\
\hline
\end{tabular}

*Aurofac 10: canola meal, 1:1 (not added to the ration during seven days prior to slaughter).

$\star \star$ Rumensin:canola meal, 1:2 (after 28 days) 
Because there were 20 different experimental treatments, the results have been summarized in different ways to facilitate comparison of the treatments. Table 43 summarizes the data to permit a comparison of steers and heifers, grain and forage-based rations, and the effect of no implant vs the use of the Synovex product. The data are averaged across the two additive treatments.

Table 44 summarizes the data to permit a valid comparison of the effects of additive and ration within sex. Because the Ralgro implant treatment was included in the steer data (there was no Ralgro treatment for the heifers due to restricted facilities), a comparison of steers and heifers is not valid. For a valid steer vs heifer comparison refer to Table 43.

Table 45 summarizes the data by ration and implant for steers fed the grain and forage-based rations.

\section{Comments (Table 43)}

1. Steers and heifers of "exotic" breeding can be properly finished on ground, good quality hay-based rations. However, it is also clear that there were too many under-finished carcasses, particularly from the forage-fed cattle. There is a tendency to over-estimate the degree of finish on ground-hay fed cattle because of their greater degree of rumen fill compared to grain-fed cattle. In other experiments the use of an ultrasonic measurement of backfat thickness greatly reduced the number of "over" and "under" finished cattle marketed.

2. Cattle fed the ground-hay based ration took about two weeks longer to finish than their grain-fed counterparts, however, an additional 1 to 2 weeks of feeding should have been carried out for about 28 of the 180 forage-fed cattle.

3. Use of the growth promoting implant increased rate of gain by $19 \%$ for steers fed either ration and by 8.5 and $10 \%$ for heifers fed the grain and forage rations, respectively. Implanted cattle gained $4.5 \%$ more efficiently on the grain-based ration, $7.1 \%$ more efficiently on the forage-based ration. On average, implanted cattle dressed out marginally higher $(0.05)$ on the grain rations and 0.6 percentage units higher on the forage-based ration. Implanted cattle increased returns by an average of $\$ 21.48$ per head (implant cost $\$ 1.75 /$ hd), with returns on forage-fed cattle averaging $\$ 26.13$ higher, and on grain-fed cattle averaging $\$ 16.83$ higher than for their unimplanted controls.

4. Implanting forage-fed cattle with the Synovex products was at least as effective, if not more effective, in improving the performance of finishing cattle as was the use of this implant for grain-fed cattle. 


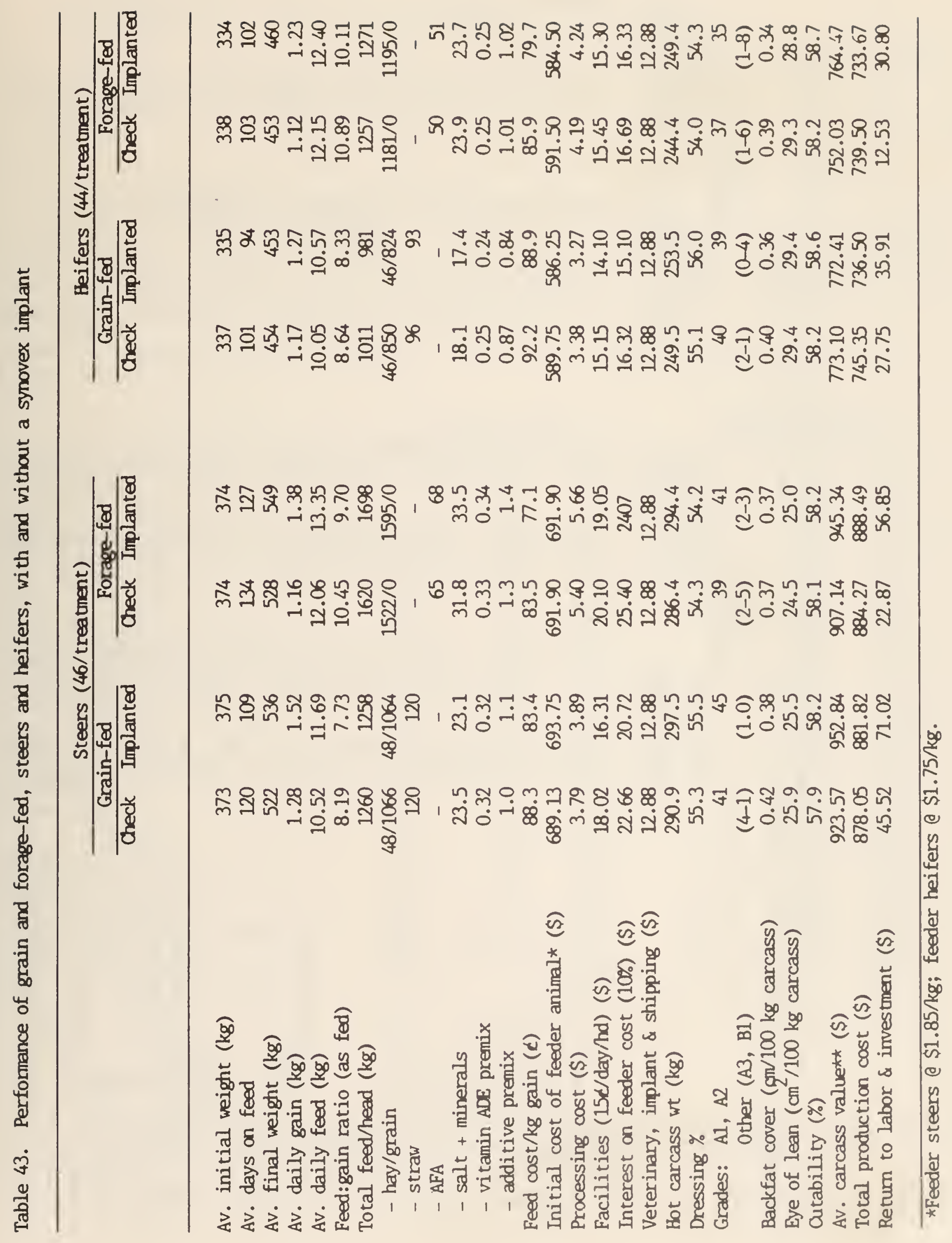




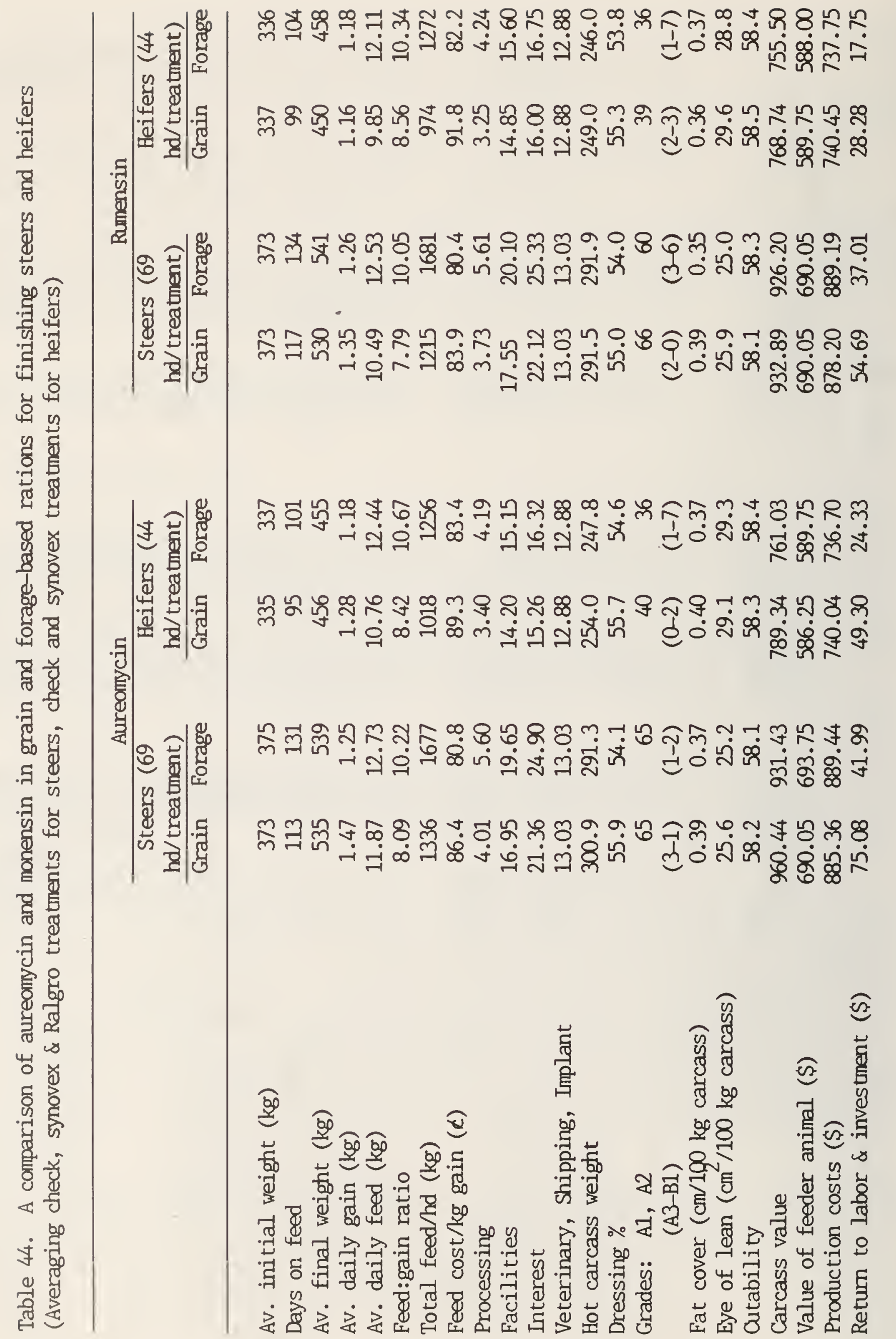


1. Supplementing with aureomycin returned more to labor and investment ( $\$ 20.70 /$ hd on grain-based rations and $\$ 5.78 /$ hd on forage-based rations) than those receiving rumensin in their ration. On average, cattle receiving rumensin took 3 to 4 days longer to reach finished condition $(0.37 \mathrm{~cm}$ vs 0.38 $\mathrm{cm}$ backfat/100 kg carcass), weighed slightly less (1.5 kg) at finish, and dressed out 0.55 percentage units less than those receiving aureomycin.

Note: The use of aureomycin in finishing rations for beef cattle is not approved by Federal authorities. In our tests, the withdrawal of aureomycin from the feed, seven days prior to slaugher, eliminated any measurable traces of the antibiotic from the meat (muscle, kidney, liver and perirenal fat).

Table 45. A comparison of Synovex S and Ralgro for steers fed grain and forage-based rations (46 steers/treatment)

\begin{tabular}{|c|c|c|c|c|c|c|}
\hline & \multicolumn{3}{|c|}{ Grain-Based Ration } & \multicolumn{3}{|c|}{ Forage-Based Ration } \\
\hline & Check & Synovex S & Ralgro & Check & Symovex S & Ralgro \\
\hline Av. initial weight $(\mathrm{kg})$ & 373 & 375 & 373 & 374 & 374 & 375 \\
\hline Days on feed & 120 & 109 & 116 & 134 & 127 & 138 \\
\hline Av. final weight $(\mathrm{kg})$ & 522 & 536 & 540 & 528 & 549 & 543 \\
\hline Av. daily gain $(\mathrm{kg})$ & 1.28 & 1.52 & 1.43 & 1.16 & 1.38 & 1.22 \\
\hline Av. daily feed (kg) & 10.52 & 11.69 & 11.34 & 12.06 & 13.35 & 12.48 \\
\hline Feed:gain ratio & 8.19 & 7.73 & 7.91 & 10.45 & 9.70 & 10.25 \\
\hline Total feed/hd (kg) & 1260 & 1258 & 1310 & 1620 & 1698 & 1721 \\
\hline Feed cost $/ \mathrm{kg}$ gain (t) & 88.4 & 83.4 & 83.8 & 83.5 & 77.1 & 81.2 \\
\hline Feed processing (\$) & 3.79 & 3.89 & 3.94 & 5.40 & 5.66 & 5.74 \\
\hline Facility charge e 15d/day & 18.00 & 16.35 & 17.40 & 20.10 & 19.05 & 20.70 \\
\hline Interest $(10 \%)$ & 22.69 & 20.72 & 21.93 & 24.03 & 22.77 & 24.81 \\
\hline Vet. \& shipping (\$) & 12.00 & 12.00 & 12.00 & 12.00 & 12.00 & 12.00 \\
\hline Inplant & - & 1.75 & 1.35 & - & 1.75 & 1.35 \\
\hline Hot carcass wt. (kg) & 290.9 & 297.5 & 300.4 & 286.4 & 297.4 & 291.2 \\
\hline Dressing \% & 55.3 & 55.5 & 55.6 & 54.3 & 54.2 & 53.7 \\
\hline Grades: $\mathrm{A} 1, \mathrm{~A} 2$ & 41 & 45 & 45 & 39 & 41 & 45 \\
\hline$(\mathrm{A} 3, \mathrm{~B} 1)$ & $(4-1)$ & $(1-0)$ & $(0-0)$ & $(2-5)$ & $(2-3)$ & $(0-0)$ \\
\hline Fat cover $(\mathrm{or} / 100 \mathrm{~kg})$ & 0.42 & 0.38 & 0.38 & 0.37 & 0.37 & 0.36 \\
\hline Eye of lean $\left(\mathrm{cm}^{2} / 100 \mathrm{~kg}\right)$ & 25.9 & 25.5 & 25.9 & 24.6 & 25.0 & 25.7 \\
\hline Qutability & 57.9 & 58.2 & 58.5 & 58.1 & 58.2 & 58.3 \\
\hline Av. carcass value $(\$)$ & 923.80 & 952.84 & 964.28 & 879.19 & 918.58 & 908.54 \\
\hline Initial value of feeder $(\$ 1.85 / \mathrm{kg})$ & 690.05 & 693.75 & 690.05 & 654.50 & 654.50 & 656.25 \\
\hline Production costs & 878.25 & 882.73 & 886.62 & 844.62 & 850.66 & 857.27 \\
\hline Av. retums to labor \& investment (\$) & 45.55 & 70.11 & 77.66 & 34.57 & 67.92 & 51.27 \\
\hline
\end{tabular}

\section{Comments (Table 45)}

1. Use of either implant resulted in improved rate of gain, better feed efficiency and heavier carcasses with slightly less backfat cover.

2. Synovex $S$ produced the highest returns to labor when administered to 
forage-fed steers while Ralgro gave higher returns when used on the grain-fed steers. In all cases, returns were substantially increased (average about $\$ 29$ for the Synovex $S$ and $\$ 24$ for the Ralgro).

3. For each dollar invested in implants, there was an average return of almost $\$ 20$ in this test.

\section{THE EPFECTS OF SUPPLEMENTING A GROHING-FINISHING RATION FOR STEERS AND HEIFERS, VITH SEVERAL FEED ADDITIVES}

As a follow-up to the test in which aureomycin was compared to monensin another experiment involving 209 crossbred steers and heifers fed a high, ground forage ration for 56 days, followed by a grain-based finishing ration, was undertaken to compare three additives, aureomycin (CTC), monensin (MON) and lasalocid (LAS) (Bovatec) with a control ration (CON) containing no additives. Aureomycin was fed at the rate of $33 \mathrm{mg} / \mathrm{kg}$, of dry matter (approx. $375 \mathrm{mg} / \mathrm{hd} /$ day), monensin at $11 \mathrm{mg} / \mathrm{kg}$ of ration dry matter for 28 days, then at $33 \mathrm{mg}$; and lasalocid at $35 \mathrm{mg} / \mathrm{kg}$ of ration dry matter. Cattle were implanted at the start of the test with Ralgro, and about 80 days later, were reimplanted with the appropriate Synovex implant. The formulas of the ground hay and rolled barley-based rations are shown in Table 46.

Table 46. Formulation and composition of rations

\begin{tabular}{|c|c|c|}
\hline \multirow[b]{2}{*}{ Item } & \multicolumn{2}{|c|}{ Ration } \\
\hline & Ground Forage & Concentrate \\
\hline & -----------9 & ---------- \\
\hline \multicolumn{3}{|l|}{ Ingredient* } \\
\hline Crested wheatgrass hay, ground $(1.27 \mathrm{~cm}$ screen) & 95.99 & --- \\
\hline Barley, rolled & --- & 85.74 \\
\hline Barley straw, ground & --- & 10.00 \\
\hline Canola acidulated fatty acids (AFA) & 3.00 & 3.00 \\
\hline Trace-mineralized, cobalt-iodized salt & 0.50 & 0.50 \\
\hline Calcium carbonate & --- & 0.50 \\
\hline Dicalcium phosphate & 0.50 & 0.25 \\
\hline Vitamin A & 0.01 & 0.01 \\
\hline & $\overline{100.00}$ & $\overline{100.00}$ \\
\hline \multicolumn{3}{|l|}{ Analys is } \\
\hline$\overline{\text { Dry matter }}$ & 91.8 & 89.7 \\
\hline Crude protein $\star \star$ & 10.7 & 11.0 \\
\hline Ash $\star \star$ & 6.6 & 3.7 \\
\hline Digestible organic matter (in vitro) $\star \star$ & 62.8 & 81.0 \\
\hline
\end{tabular}

*Feed costs: Crested wheatgrass hay, \$55/tonne; Barley, \$66/tonne; Straw, $\$ 33 /$ tonne; Acidulated fatty acids (from canola), $\$ 0.44 / \mathrm{kg}$;

Trace-mineralized, cobalt-iodized salt, $\$ 0.308 / \mathrm{kg} ;$ Limestone, $\$ 0.1188 / \mathrm{kg}$; Dicalcium phosphate, $\$ 0.704 / \mathrm{kg}$; Vitamin A (10 $000 \mathrm{IU} / \mathrm{g})$ supplement, $\$ 1.28 / \mathrm{kg} ;$ CTC (Aurofac $50,110 \mathrm{~g} / \mathrm{kg} \$ 5.39 / \mathrm{kg}$ ); MON (rumensin, $132 \mathrm{~g} / \mathrm{kg}$ ), $\$ 15.29 / \mathrm{kg}$; and LAS (Bovatec, $150 \mathrm{~g} / \mathrm{kg}$ ), $\$ 15.91 / \mathrm{kg}$.

$\star \star$ Dry matter basis. 
The performance of the cattle averaged across sex and weight groups is summarized in Table 47, including both feeding periods.

The aureomycin supplement was not added to the ration during the seven day period prior to slaughter, so that all detectable traces of it would be removed from the tissue by the time the animals were slaughtered.

Table 47. Effect of feed additives on performance of beef cattle averaging across sex and weight groups

CON $\quad$ CTC MON LAS

\section{Animal Performance}

\section{Number of head}

Average age on test (days)

Average initial weight $(\mathrm{kg})$

Days on test

Average final weight $(\mathrm{kg})$

Average daily gain $(\mathrm{kg})$

Average daily feed eaten $(\mathrm{kg})$ *

Feed:Gain ratio*

Carcass data

Warm carcass weight $(\mathrm{kg})$

Dressing \%

Average backfat thickness (mm)

Area of loin eye $\left(\mathrm{cm}^{2}\right)$

Cutability (\%)

Grades: A1, A2

A3

B1

\section{Economics}

Carcass value ( $\$$ )

Adjusted carcass value ( $\$) \star \star$

Initial value of feeder ( $\$$ )

Production costs

Feed (\$)

other $(\$)$

Total (\$)

Average returns to labor ( $\$$ )

Adjusted returns to labor $(\$) * *$
51

419

387.6

104

519.3

1.27

12.05

9.92

270.0

52.02

7.4

78

59.6

49

0

2

809.38

813.92

636.66

859.11

834.20

823.09

860.12

834.20

827.87

637.59

637.46

636.39

\subsection{3}

$\frac{53.56}{146.89}$

104.59

25.83

30.37 $\frac{54.16}{158.75}$

62.47
61.46
95.12

53.00

148.12

48.52

48.52
52

423

387.5

99

523.5

1.36

12.11

9.09

275.0

52.44

7.8

80

59.6

48

1

3

94.08

51.46

145.54

41.10

45.88

*Based on feed as eaten (approx. $90 \%$ dry matter).

$* *$ Based on all carcasses grading $\mathrm{Al}$. 


\section{Comments (Table 47)}

1. All three additives produced beneficial effects on animal performance or/and carcass quality and yield, and on return to labor.

2. Analyses for aureomycin residues in liver, muscle and kidney samples, showed only $10 \%$ of the animals to have any traces of antibiotic and that the level measured was below the lowest limit for reliable measurement (100 parts per billion). Repeat analyses detected no residue.

3. While aureomycin is not yet approved in Canada for use in cattle finishing rations, the results of this experiment clearly indicated its marked beneficial effect on animal performance and financial returns and that no antibiotic residues remain in the meat provided that the feeding of the antibiotic is discontinued for at least seven days prior to slaughter.

\section{TEN TIPS FOR UTILIZING GROUND HAY IN BEEF CATTLE RATIONS}

1. Manage hay harvesting and storage system to provide as dry a hay as possible at the time of processing.

2. Use a $13 \mathrm{~mm}$ screen if processing hays for inclusion in complete rations. This will minimize settling out of other fine-particled ration components. If feeding hay separately, grinding through a $25 \mathrm{~mm}$ screen may be better if using a good-to-high quality hay.

3. Grinding will result in a greater increase in the efficiency of utilizing poorer quality hays than for good quality hays.

4. Self-feed the processed hay. Unless cattle are allowed to eat all they can, there will be little or no benefit from processing, except if it will result in reducing wastage (sorting) of stemmy feed.

5. Process forage as it is required, particularly if it is over $10 \%$ moisture and the weather is warm. Storing such feed may allow spoilage and/or spontaneous combustion to occur.

6. Check hay, for stones, metal or any other contaminant that could damage screens or lead to a fire. Install magnetic device or metal detector on bale feeder.

7. Keep hammers sharp and provide adequate power to operate the processing equipment at full capacity, otherwise energy will be inefficiently used. Consider use of electrically powered grinding equipment.

8. Do not grind roughage for animals capable of performing at the required level on unprocessed feed. Excess feed intake could mean overfat beef cows, while limiting intake to meet nutritional requirements, would 
require extra labor and result in unsatisfied cows.

9. Supplement ground hay rations with acidulated acids, canola oil, tallow, etc., if available at reasonable cost. At $2 \%$, these supplements will eliminate dustiness and at $2-4 \%$ will help to improve the energy:protein ratio of high-protein hay rations.

10. As with any other ration, be sure that salt, mineral supplements, vitamin A (if forages are not a bright green color) and an antibiotic supplement (for growing cattle) are part of the management package. Implanting non-breeding stock will improve performance.

\section{ADVANTAGES OF GRINDING HAYS}

1. Reduces wastage normally encountered when feeding long hay.

2. Permits preparation of complete rations to assure consistent nutrient intake.

3. Increases density of feed allowing greater intake and more efficient use of feed.

4. Permits automated mechanical handling.

5. Reduces energy required to chew, swallow and regurgitate feed.

6. Increases surface area of the feed thus increasing access by rumen microflora to enhance digestion of nutrients.

7. Promotes an increase in the propionic:acetic acid ratio in the rumen, resulting in more efficient utilization of feed (might reduce butterfat levels in milk of dairy cattle).

Note: Grinding hays may result in a reduction of apparent digestibility due to increasing the rate of passage through the digestive system, which limits the time for absorption of the digested nutrients. This is usually more than compensated for by the marked increase in nutrient intake.

\section{VINTERING BEEF COUS IN THE ASPEN PARKBELT}

The winter feeding period for the beef herd in the Aspen Parkbelt is long, averaging from mid- to late-0ctober until the last week in May. Thus availability of adequate supplies of feed and bedding at a low cost is the key to the profitability of the cow-calf enterprise.

While feeding some medium to good quality hay or silage is highly desirable from a nutritional standpoint, full feeding of such forages is 
usually wasteful and costly. However, limiting the amount of forages to just meet requirements, creates prohlems, in that animals cannot satisfy their appetites and it is difficult to ensure that all animals in the herd get their fair share of the feed.

The solution to the problem is to allow animals to have free access to cereal (or other crop) straw and to feed enough forage and, if required, grain to support the level of performance desired.

Since 1974, research has been conducted to determine the feed intake and performance of wintering beef cows. Originally, Hereford cows were involved but over the years, the 300 cow herd has been replaced with two kinds of crossbreeds, Angus $x$ Hereford and Simmental $x$ Hereford. In the earlier years, half of each of these "breeds" of cows were bred to calve in January and February and half in April and May. The results insofar as intake and performance on various rations are presented in Tables 48 and 49.

Table 48. Winter feed consumption of early vs late calving beef cows at Melfort ( $90 \%$ dry matter basis)

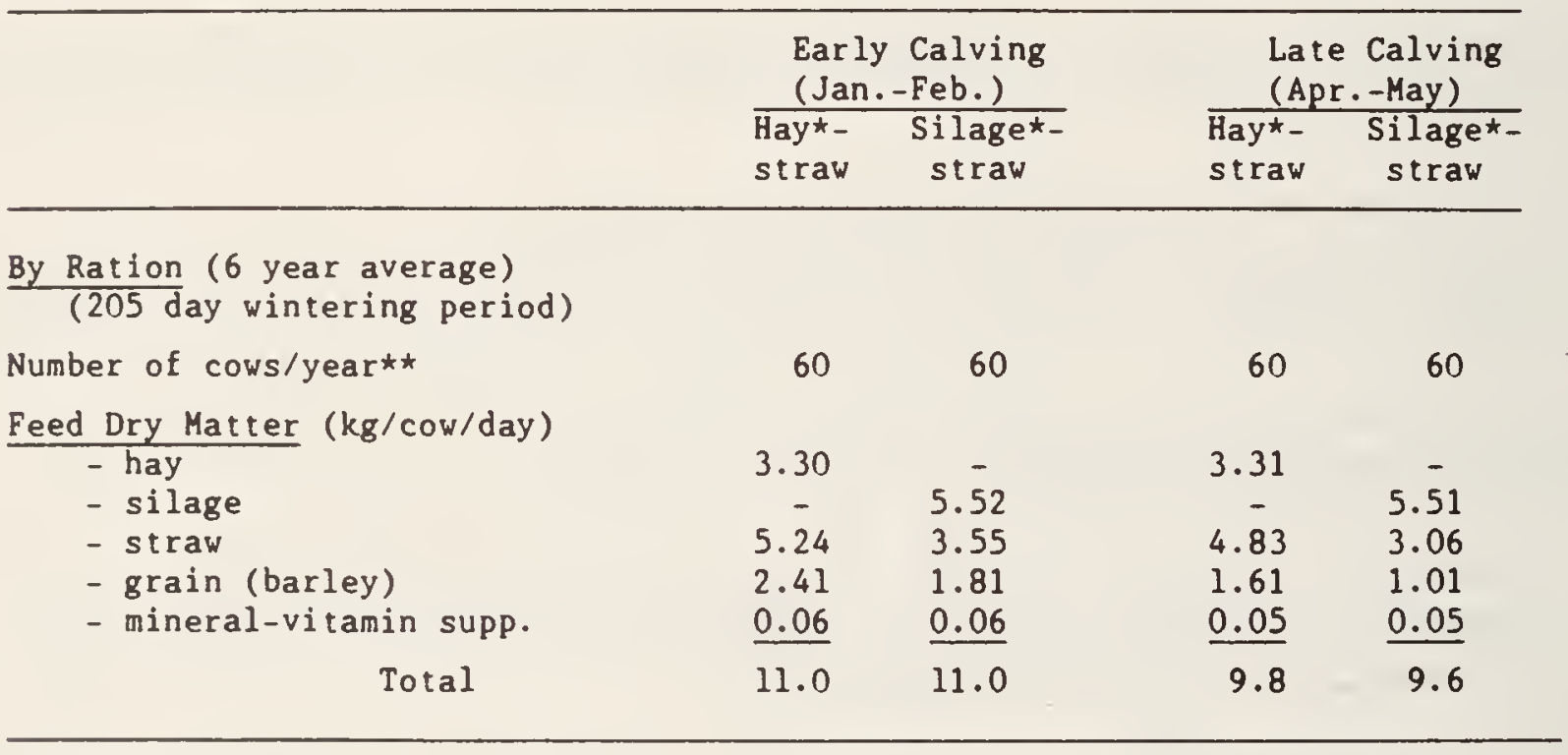

$\star$ Brome-alfalfa

Table 49. Average feed intake by wintering cows ( $90 \%$ DM basis) ( 5 year average, 201 day feeding period)

\begin{tabular}{|c|c|c|c|c|}
\hline & \multirow{2}{*}{\multicolumn{2}{|c|}{$\begin{array}{lc}\text { Angus } x & \text { Hereford } \\
\text { Early } & \text { Late } \\
\text { calving } & \text { calving }\end{array}$}} & \multicolumn{2}{|c|}{$\begin{array}{l}\text { Simmental } \\
\times \text { Hereford }\end{array}$} \\
\hline & & & $\begin{array}{l}\text { Early } \\
\text { calving }\end{array}$ & $\begin{array}{c}\text { Late } \\
\text { calving }\end{array}$ \\
\hline $\begin{array}{l}\text { Average initial weight }(\mathrm{kg}) \\
\text { Average final weight }(\mathrm{kg})\end{array}$ & $\begin{array}{l}554 \\
511\end{array}$ & $\begin{array}{l}517 \\
500\end{array}$ & $\begin{array}{l}579 \\
530\end{array}$ & $\begin{array}{l}551 \\
529\end{array}$ \\
\hline \multicolumn{5}{|l|}{ Average DM Intake (kg) } \\
\hline $\begin{array}{l}\text { - silage } \star \text { hay } \\
\text { - barley } \\
\text { - straw }\end{array}$ & $\begin{array}{l}5.46 \\
2.02 \\
4.14 \\
11.6\end{array}$ & $\begin{array}{l}4.77 \\
1.41 \\
4.16 \\
10.3\end{array}$ & $\begin{array}{r}5.81 \\
2.02 \\
4.44 \\
12.3\end{array}$ & $\begin{array}{l}5.13 \\
1.52 \\
4.93 \\
11.6\end{array}$ \\
\hline
\end{tabular}

*Cereal silage (mainly barley). 
Comments (Tables 48 and 49)

1. Average daily feed intakes can be used to provide an estimate of feed consumption for cows of different sizes, calving at different times. Note that, depending on the test period, intakes of dry matter differ. For predicting winter feed requirements one would be wise to assure at least a $20 \%$ "surplus" to allow for longer or more severe winters than is the case on average.

2. Length of feeding periods in Tables 48 and 49 , are not indicative of the normal length of the wintering period (approximately 230 days).

The straw used for wintering cows is normally that produced on the operator's land. However, if there is an option or if straw must be purchased, it is important to consider quality.

Straw, by its very nature, is a variable product, with such factors as species and variety of crop, maturity at harvest, weathering, efficiency of the threshing process and contamination with weeds, all affecting feeding value. At Melfort, feeding trials with sheep showed that straw of 2-row barley varieties tended to be superior to those of 6 -row varieties. follows.

Analyses of common cereal straws in the Aspen Parkbelt is summarized as

\begin{tabular}{lllll} 
Cereal straw & Crude Protein (\%) & (Range) & TDN (\%) & (Range) \\
\hline Oats & 3.88 & $(1.4-8.0)$ & 38.5 & $(31-46)$ \\
Barley & 4.37 & $(1.8-7.7)$ & 39.2 & $(29-48)$ \\
Wheat & 3.75 & $(1.8-6.8)$ & 35.3 & $(29-44)$
\end{tabular}

Source: Sask. Feed Testing Lab

Obviously there is a wide range in feeding value and the cow-calf operator would be prudent to have his straw supply analysed so that he can use it effectively in his feeding program.

\section{AMMONIATING BARLEY STRAW FOR WINTERING BEEF COW RATIONS}

In the Aspen Parkbelt, cereal straw is a major constituent of wintering rations for beef cows. However, straw is normally deficient in both protein and energy (as well as vitamin A and minerals) and is usually supplemented 
with some good quality grass-legume hay or silage and grain as required to maintain desired body condition.

In years when forages are in short supply and/or high priced, it would be useful to increase the amount of straw fed, without leading to impaction. This would mean that the feeding value (digestibility) of the straw would have to be increased.

Treating cereal (and flax) straw with $3.5 \%$ anhydrous ammonia (DM basis) can increase TDN to around $50 \%$ (from $40 \%$ or less) and crude protein to $6-8 \%$ (from around $3-4 \%$ ). It also increases palatability (intake) by from $30-40 \%$ on average. Cost will vary from \$17-33/tonne, depending on a number of conditions including the amount of material in the stack. If, for example, ammoniation costs $\$ 22$ to obtain an extra $100 \mathrm{~kg}$ of TDN or an extra $40 \mathrm{~kg}$ of protein, then, if supplemental feeds were worth less than as follows, they would be the most economical source of nutrients.

\section{Nutrient Source}

Wheat e $15 \% \mathrm{CP}$

Hay e $12 \% \mathrm{CP}$

Canola meal ( $34 \% \mathrm{CP})$

TDN
$25 c / \mathrm{kg}(\$ 7 \mathrm{bu}$.
$11 \mathrm{c} / \mathrm{kg}(\$ 110 /$ tonne $)$
$\$ 7.26 / \mathrm{kg}(\$ 72.60 /$ tonne $)$

\begin{tabular}{l}
\multicolumn{1}{c}{ Crude Protein } \\
$8.25 \mathrm{k} / \mathrm{kg}(\$ 2.25 / \mathrm{bu})$. \\
$6.6 \mathrm{~kg}(\$ 66 /$ tonne $)$ \\
$\$ 18.16 / \mathrm{kg}$ (\$181/tonne)
\end{tabular}

While in an emergency, adequate rations for mature beef cows can be formulated from grain and straw (plus vitamins and minerals), it is important to recognize that for growing heifers destined for the breeding herd, good quality forages are very important. Research at the Lethbridge station has shown that the lifetime reproductive performance of heifers raised on forage-based rations was superior to that of heifers fed grain and straw-based rations.

An experiment was undertaken at Melfort in two successive years, to evaluate ammoniated and untreated straw, using Bonanza straw one winter and Klages straw in the next winter. Mature beef cows were allotted to two comparable groups. The control group was fed brome-alfalfa hay and canola meal in amounts to match the gains of the "ammoniated straw"-fed cattle, while the barley (fed to both groups) was increased from $1.8 \mathrm{~kg} / \mathrm{head}$ daily to $2.4 \mathrm{~kg}$ over a five week period preceding calving. (Wintering period was about 200 days.)

The straw was treated with anhydrous ammonia at the rate of $3.5 \%$ on a dry matter basis. The condensed results are presented in Tables 50 and 51. 
Table 50. Chemical composition of untreated and ammoniated straws (\% DM)

\begin{tabular}{lrrrr}
\hline & \multicolumn{2}{c}{ Control } & \multicolumn{2}{c}{ Ammoniated } \\
\cline { 2 - 5 } Cultivar & $\begin{array}{r}\text { Year } 1 \\
\text { Year 2 }\end{array}$ & & Year 1 & Year 2 \\
& $\frac{(82-83)}{\text { Bonanza }}$ & $\frac{(83-84)}{\text { Klages }}$ & $\frac{(82-83)}{\text { Bonanza }}$ & $\frac{(83-84)}{\text { Klages }}$ \\
\hline Dry matter & 87.1 & 84.0 & 80.6 & 82.3 \\
Crude protein & 5.2 & 3.9 & 7.4 & 6.1 \\
Organic matter digestibility & 36.5 & 29.3 & 41.9 & 35.1 \\
\hline
\end{tabular}

Table 51. Ammoniated straw for wintering beef cows (average 2 years) (total 21 cow/ration)

Control

Average initial weight $(\mathrm{kg})$

Average final weight $(\mathrm{kg})$

Average daily loss (kg)

Depth of backfat ( $\mathrm{mm}$ )

- November

- May

Calf birth weight ( $\mathrm{kg}$ )
528

518

0.05

4.5

2.2

39.5

Nov-Mar Apr-May

5.5

1.55

1.72

$\frac{0.34}{9.11}$

9.11

- hay

- barley

- canola meal

Total

Average* feed cost/day (c)

Ammoniated

537

524

0.06

5.7

3.3

39.8

*Barley straw, \$33/tonne; Ammoniated barley straw, \$57/tonne; Hay, \$78/tonne; Barley, \$110/tonne; Canola meal, \$325/tonne.

\section{Comments}

1. Under the conditions of this test the ammoniated straw successfully replaced the hay and canola meal in the control ration. 
2. When hay and grain prices are high, ammoniating cereal straw may be an economical alternative. The feeder is callioned, however, that vitamin $A$ and mineral requirements for cattle fed the grain and ammoniated straw diet will not be met as well (if at all) as when fed the ration containing some good quality hay or silage. Adequate amounts of both vitamin $A$ and minerals must be supplied to wintering beef cows.

\section{FINISHING LAMBS ON FORAGE-BASED RATIONS}

\section{USING GOOD QUALITY ALFALFA IN LAMB FINISHING RATIONS}

The effects of hay:grain ratio, pelleting and the addition of tallow or rapeseed oil on the utilization of excellent-quality, ground ( $5 \mathrm{~mm} s \mathrm{seen}$ ) alfalfa hay $(16 \mathrm{CP})$ by lambs was determined. Barley ( $12 \% \mathrm{CP})$; and $20 \%$ ground wheat straw were included to provide a better energy:protein ratio of the ration. Ground alfalfa was fed at $10,30,50$ and $70 \%$ of the ration, and at each level was supplemented with either no fat, $5 \%$ tallow or $5 \%$ canola oil. Rations were ground and pelleted $(0.64 \mathrm{~cm}$ diameter) and fed to crossbred lambs $(29.5 \mathrm{~kg})$, in individual stalls. Lambs were fed to appetite and given free access to cobalt-iodized salt and water.

Digestibility of the rations was determined, both with the lambs (in vivo) and by means of an artificial rumen technique (in vitro). The rations and results are given in Tables 52 and 53, respectively.

Table 52. Composition of lamb finishing rations using ground, high quality alfalfa hay (\%)

\begin{tabular}{|c|c|c|c|c|c|c|c|c|}
\hline & \multicolumn{2}{|c|}{ 30\% Roughage } & \multicolumn{2}{|c|}{ 50\% Roughage } & \multicolumn{2}{|c|}{$70 \%$ Roughage } & \multicolumn{2}{|c|}{$90 \%$ Roughage } \\
\hline & check & + Fat & Check & + Fat & Check & + Fat & Check & + Fat \\
\hline Alfalfa hay (ground $5 \mathrm{~mm}$ screen) & 9.9 & 9.4 & 29.8 & 28.3 & 49.6 & 47.1 & 69.5 & 66.0 \\
\hline Wheat straw (ground $5 \mathrm{~mm}$ screen) & 19.9 & 18.9 & 19.9 & 18.9 & 19.9 & 18.9 & 19.8 & 18.8 \\
\hline Barley (rolled) & 69.4 & 65.9 & 49.7 & 47.2 & 29.8 & 28.3 & 9.9 & 9.4 \\
\hline Tallow/canola oil & - & 5.0 & - & 5.0 & - & 5.0 & - & 5.0 \\
\hline Cobalt-iodized salt & 0.5 & 0.5 & 0.5 & 0.5 & 0.5 & 0.5 & 0.5 & 0.5 \\
\hline Phosphorus supplement (25\% P) & 0.05 & 0.05 & 0.1 & 0.1 & 0.15 & 0.15 & 0.2 & 0.2 \\
\hline Limestane & 0.20 & 0.2 & - & - & - & - & - & - \\
\hline $\begin{array}{l}\text { Vitamin ADE supplement }(10,000 \mathrm{~A} \text {, } \\
1,000 \mathrm{D}, 10 \mathrm{E} / \mathrm{g})\end{array}$ & 0.02 & 0.02 & 0.02 & 0.02 & 0.02 & 0.02 & 0.02 & 0.02 \\
\hline Aurofac 10 & 0.08 & 0.08 & 0.08 & 0.08 & 0.08 & 0.08 & 0.08 & 0.08 \\
\hline Total & 100.0 & 100.0 & 100.0 & 100.0 & 100.0 & 100.0 & 100.0 & 100.0 \\
\hline Crude protein & 10.6 & 10.1 & 11.5 & 10.9 & 12.3 & 11.7 & 13.1 & 12.5 \\
\hline Est. TuN & 67 & 74 & 62 & 69 & 57 & 64 & 51 & 59 \\
\hline
\end{tabular}


Table 53. Lamb performance on alfalfa finishing rations

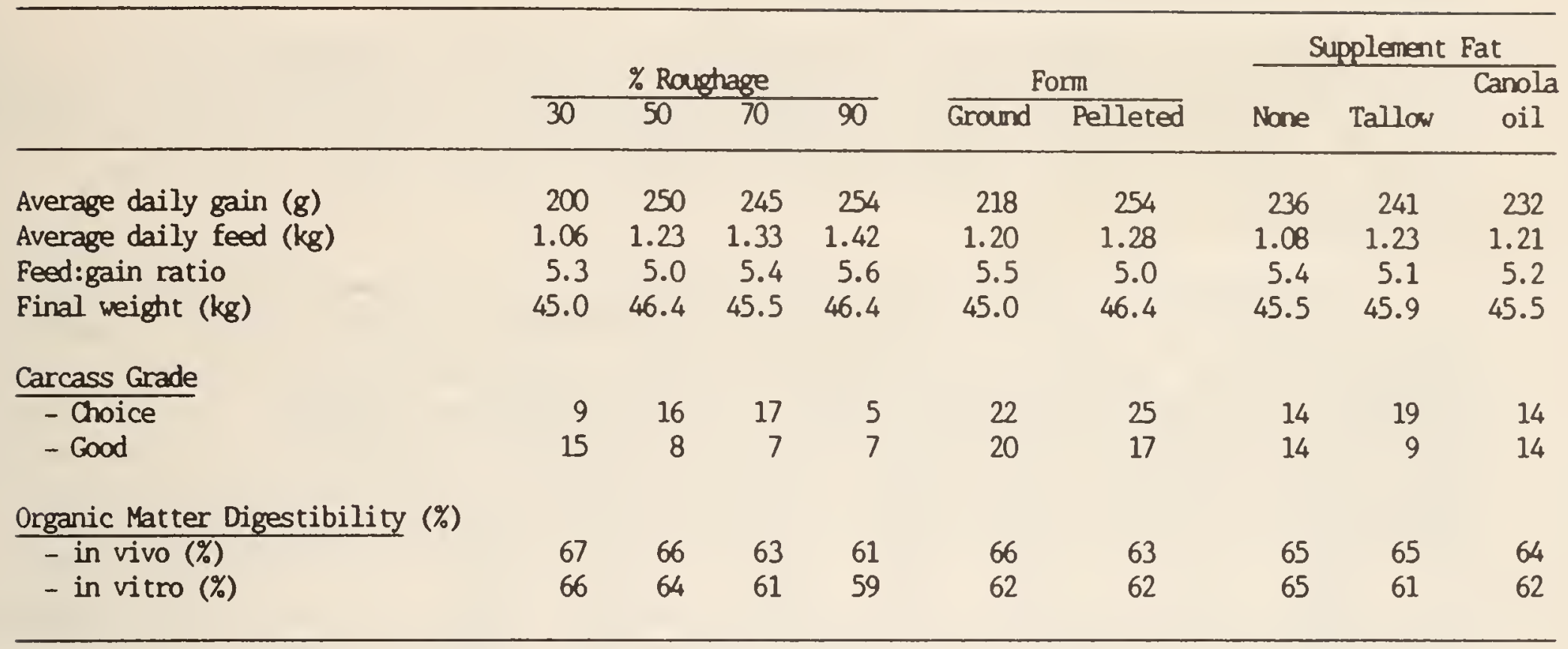

\section{Comments (Table 53)}

1. At the higher levels of roughage (50-90\%), rate of gain was $25 \%$ higher than at the $30 \%$ roughage level. Feed required per unit of gain was lowest when roughage was fed at $50 \%$, but dressing percentage and carcass grades were slightly better at the $70 \%$ roughage level.

2. Pelleting increased the rate of liveweight gain by an average of $17 \%$, improved feed:gain ratios by about $9 \%$ and improved dressing percentages and grades. The most marked effect of pelleting on rate of gain and feed efficiency occurred with the low-roughage ration without supplemental fat. Thus, it appears that rations containing high levels (50-70\%) of ground, good quality alfalfa with or without added fat may not be markedly improved by pelleting.

3. Adding tallow or oil to the low roughage ration reduced rates of gain on ground and pelleted rations by 15 and 20\%, respectively. Adding tallow or oil to the 50 and $70 \%$ rations, whether ground or pelleted, had little effect on animal gain; but with the $90 \%$ rations, tallow or oil improved rate of gain by $46 \%$ on the ground ration and $17 \%$ on the pelleted ration.

4. Lambs fed the $30,50,70$ and $90 \%$ roughage rations required $3.8,3.4$, 3.3 and $3.2 \mathrm{~kg}$ of digestible nutrients per $\mathrm{kg}$ gain. This indicates that under the conditions of this experiment, the level of roughage had no adverse effect on the efficiency of energy utilization. 


\section{CRESTED VHEATGRASS HAY FOR FINISHING LAMBS}

Crested wheatgrass is well adapted to the Aspen Parkbelt and has yielded well, both as pasture and hay. Its use in lamb finishing rations containing 50,70 and $90 \%$ ground ( $5 \mathrm{~mm}$ screen) crested wheatgrass and one in which the level of hay started at $90 \%$ and was reduced by $5 \%$ a week to $50 \%$, was evaluated.

Crossbred lambs were weaned off pasture at an average weight of $30.4 \mathrm{~kg}$ and hand-fed to appetite once daily in individual stalls. Cobalt-iodized salt and water were available at all times. The hay was made up of equal parts of Fairway and Parkway varieties and analyzed $10.8 \%$ CP (90\% DM basis). The remainder was mainly rolled wheat $(16.8 \% \mathrm{CP})$. Three of the rations are given in Table 54; the fourth, varying from 90 to $50 \%$ crested wheatgrass, was prepared by using these rations in various proportions as required.

Each ration was fed both ground and pelleted. Ewe and wether lambs were equally represented in all ration treatments. Carcass grades and measurements were obtained. Animal performance is summarized in Table 55.

Table 54. Composition of crested wheatgrass-based lamb finishing rations (\%)

\begin{tabular}{|c|c|c|c|}
\hline & $90 \%$ & $70 \%$ & $50 \%$ \\
\hline Crested wheatgrass & 89.2 & 69.4 & 49.54 \\
\hline Rolled wheat & 9.9 & 29.7 & 49.54 \\
\hline Cobal-iodized salt & 0.5 & 0.5 & 0.5 \\
\hline Limestone & - & 0.16 & 0.32 \\
\hline Calcium phosphate $(19 \% \mathrm{Ca}, 19 \% \mathrm{P})$ & 0.32 & 0.16 & - \\
\hline $\begin{array}{l}\text { Vitamin ADE supplement }(10,000 \text { IU A, } \\
1,000 \text { IU D, } 10 \text { IU E/g) }\end{array}$ & 0.02 & 0.02 & 0.02 \\
\hline Aurofac 10 & $\frac{0.08}{100.0}$ & $\frac{0.08}{100.0}$ & $\frac{0.08}{100.0}$ \\
\hline
\end{tabular}

\section{Comments (Table 54)}

1. Pelleting increased rate of gain, feed conversion efficiency and in all but one case, dressing percentage. The $90 \%$ roughage ration was the most profitable of the pelleted rations. Pelleting increased consumption by 24 , 18,15 and $17 \%$ on the $90 \%, 70 \%, 50 \%$ and $90-50 \%$ hay rations, respectively, to increase rate of gain by an average of $47 \%$, the greatest increase $(66 \%)$ occurring with the $90 \%$ hay ration and the least (33\%) with the ration in which hay content was reduced from 90 to 50\%. Pelleting improved feed efficiency (22\%), with the greatest improvement $(32 \%)$ occurring with the $90 \%$ hay ration. Averaging all rations, pelleting improved dressing percentage 
( 46.6 vs $45.8 \%$ ), grades ( 97 vs $75 \%$ Choice) and returns to labor.

2. When ground rations were fed, there was a slight increase in rate of gain, feed efficiency and dressing percentage as the hay level decreased, with the $70 \%$ roughage level providing the best overall performance.

3. Performance was about the same for ewe and wether lambs.

Table 55. Lamb performance on crested wheatgrass finishing rations

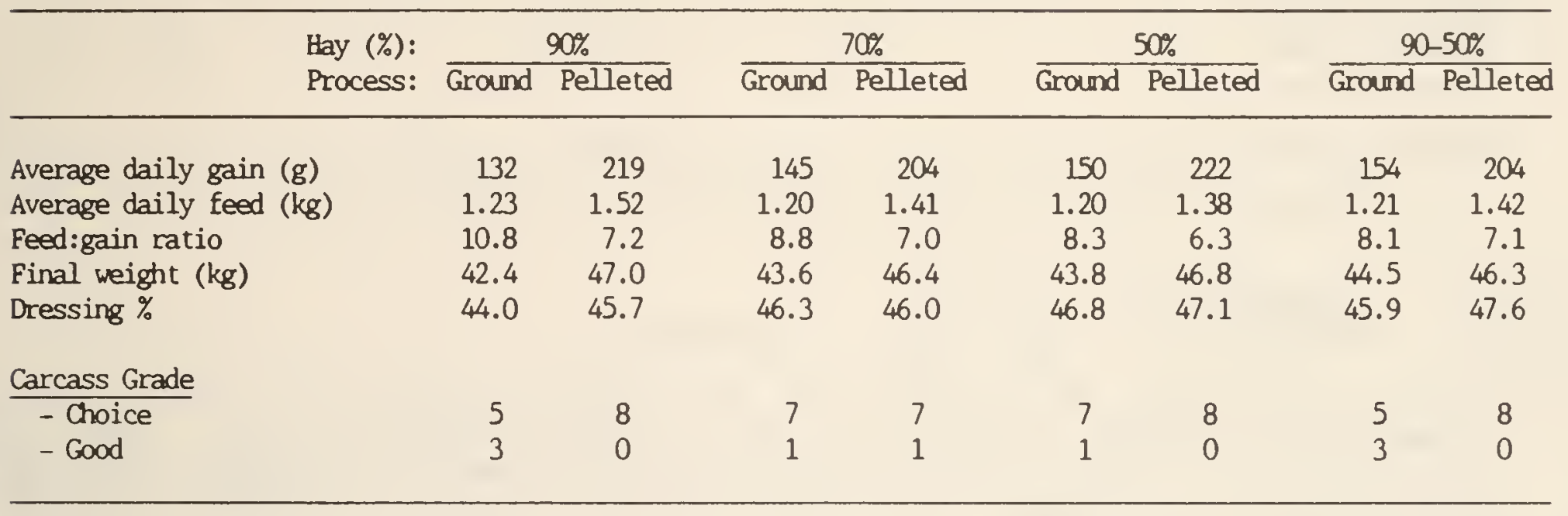

\section{SLOUGH HAY FOR FINISHING LAMBS}

"Slough" hay is found around many non-saline pot holes and sloughs throughout the Aspen Parkbelt. If harvested prior to becoming too mature, it can be a very useful feed. Grinding will improve its feeding value.

Crossbred lambs $(33.6 \mathrm{~kg})$ were weaned off pasture and hand-fed to appetite in individual stalls. Four rations, all containing $0.5 \%$ cobalt-iodized salt, $0.2 \%$ calcium phosphate $(19 \% \mathrm{Ca}, 19 \% \mathrm{P}), 0.22 \%$ vitamin $\mathrm{A}$ supplement $(10,000 \mathrm{IU} / \mathrm{g})$ and $0.80 \%$ antibiotic supplement were formulated to contain the percentages of basal feeds shown in Table 56. All rations were fed both ground $\left(192 \mathrm{~kg} / \mathrm{m}^{2}\right.$ ) and pelleted (5 mm diameter, average density 632 $\left.\mathrm{kg} / \mathrm{m}^{2}\right)$. The results appear in Table 57. 
Table 56. Slough hay in lamb finishing rations (\%)

\begin{tabular}{lcccc}
\hline & Control & $\begin{array}{c}2 \% \\
\text { molasses }\end{array}$ & $\begin{array}{c}10 \% \\
\text { alfalfa } \\
\text { meal }\end{array}$ & $\begin{array}{c}5 \% \\
\text { rapeseed } \\
\text { meal }\end{array}$ \\
\hline $\begin{array}{l}\text { Slough hay (11\% CP) } \\
\quad \text { (ground 5 mm screen) }\end{array}$ & 69.5 & 66.1 & 59.5 & 66.1 \\
$\begin{array}{l}\text { Wheat (15.5\% CP) (coarsely ground) } \\
\text { Beet molasses }\end{array}$ & 29.8 & 28.1 & 29.8 & 28.1 \\
$\begin{array}{l}\text { Alfalfa meal } \\
\text { Rapeseed meal } \\
\text { Crude protein (\%) }\end{array}$ & - & 5.0 & - & - \\
\end{tabular}

\section{Comment (Table 56)}

1. Pelleting had no effect on the feeding value of the unsupplemented slough grass ration. Addition of any of the supplements to the ground form of the control ration reduced rate of gain and feed efficiency. In contrast, inclusion of a supplement in pelleted rations markedly increased rate of gain and feed efficiency.

The ability of finishing lambs to perform so well on a ration comprising such a high percentage of slough hay, once again demonstrates the role roughages can play in ruminant rations, provided they are processed and used in conjunction with other feeds and supplements required to balance the deficiencies of the roughages.

Table 57. Lamb performance on slough hay rations

\begin{tabular}{|c|c|c|c|c|c|c|c|c|}
\hline \multirow{2}{*}{$\begin{array}{l}\text { Supplement: } \\
\text { Process: }\end{array}$} & \multicolumn{2}{|c|}{ Control } & \multicolumn{2}{|c|}{ 5\% Molasses } & \multicolumn{2}{|c|}{ 10\% Alfalfa Meal } & \multicolumn{2}{|c|}{ 5\% Canola Meal } \\
\hline & Ground & Pelleted & Ground & Pelleted & Ground & Pelleted & Ground & Pelleted \\
\hline Average daily gain (g) & 209 & 218 & 136 & 277 & 182 & 272 & 182 & 250 \\
\hline Average daily feed $(\mathrm{kg})$ & 1.34 & 1.39 & 1.09 & 1.43 & 1.27 & 1.50 & 1.30 & 1.58 \\
\hline Feed:gain ratio & 6.64 & 6.74 & 9.07 & 5.27 & 7.51 & 5.58 & 7.25 & 6.47 \\
\hline Final weight $(\mathrm{kg})$ & 44.9 & 45.6 & 40.5 & 49.2 & 43.6 & 49.0 & 43.4 & 49.2 \\
\hline Dressing \% & 46.9 & 46.8 & 47.8 & 46.0 & 47.3 & 47.2 & 46.4 & 48.3 \\
\hline \multicolumn{9}{|l|}{ Carcass Grade } \\
\hline- Good & 4 & 4 & 1 & 4 & 3 & 4 & 3 & 4 \\
\hline - Commercial & 0 & 0 & 3 & 0 & 1 & 0 & 1 & 0 \\
\hline
\end{tabular}




\section{EFFECT OF MOISTENING ON THE FEEDING VALUE OF GROUND HAYS FED TO LAMBS}

Ground hays tend to be very dusty, which may limit palatability. Dust can be eliminated by adding tallow, feeding oils, molasses or water to the ration. Forty-eight lambs averaging about $28 \mathrm{~kg}$ when weaned off pastur $\epsilon$, were individually fed one of four ground ( $5 \mathrm{~mm}$ screen) forages - alfalfa $(16.5 \% \mathrm{CP})$, bromegrass $(13.5 \% \mathrm{CP})$, crested wheatgrass $(15.5 \% \mathrm{CP})$ and meadow fescue ( $9 \% \mathrm{CP}$ ) - as the sole diet (other than salt and water) for 8 weeks. Half of the lambs fed each hay received the ground hay mixed with an equal weight of water. Following the growing period the rations were supplemented with $20 \%$ of a grain, mineral, vitamin $\mathrm{A}$ mix. The results are presented in Table 58 .

Table 58. Lamb performance on moist (M) and dry (D) ground hays*

\begin{tabular}{lllll} 
Alfalfa & $\begin{array}{l}\text { Brome- } \\
\text { grass }\end{array}$ & $\begin{array}{l}\text { Crested } \\
\text { wheat }\end{array}$ & $\begin{array}{l}\text { Meadow } \\
\text { fescue }\end{array}$ \\
\hline$D$ & D & $M$
\end{tabular}

\section{Growing Period}

Average daily gain ( $g$ )

$127 \quad 163$

$123 \quad 141$

$200 \quad 163$

104

163

Average daily feed ( $\mathrm{kg}$ )

$1.22 \quad 1.42$

$1.19 \quad 1.28$

$1.32 \quad 1.25$

$1.12 \quad 1.28$

Feed/unit gain

$9.6 \quad 8.7$

$9.7 \quad 9.1$

6.67 .6

$10.7 \quad 7.8$

Finishing Period

Average daily gain (g)

168

222

$141 \quad 154$

136209

$154 \quad 168$

Average daily feed ( $k g$ )

$1.78 \quad 1.76$

1.591 .75

$1.97 \quad 2.07$

$1.48 \quad i .80$

Feed/unit gain

$10.6 \quad 7.9$

11.311 .3

$14.5 \quad 9.9$

$9.6 \quad 10.7$

Final weight $(\mathrm{kg})$

$42.3 \quad 43.2$

$43.2 \quad 43.2$

$41.4 \quad 43.6$

$42.3 \quad 42.7$

Total Period

Average daily gain (g)

Feed/unit gain

$\begin{array}{rrrrrrrr}99 & 83 & 115 & 103 & 72 & 89 & 111 & 89 \\ 144 & 183 & 132 & 148 & 186 & 175 & 129 & 165 \\ 10.1 & 8.4 & 10.6 & 10.1 & 7.9 & 8.6 & 10.1 & 8.9\end{array}$

*All carcasses graded either Canada Choice or Canada Good.

\section{Comments (Table 58)}

1. Lambs fed ground alfalfa, bromegrass and meadow fescue hays performed better (av. 33\% faster gains, $14 \%$ better feed conversion) when fed the moistened hays.

2. Moistening the crested wheat hay reduced performance, but it is interesting to note that lambs fed the dry crested wheatgrass outgained those fed the other hays and that crested wheatgrass, when fed either dry or 
moistened, produced more gain per unit of feed than did the other forages, during the growing period.

3. Despite the low crude protein content of the meadow fescue hay, lambs performed well, especially when the hay was moistened.

4. Adding grain (20\%) to the ground hays, increased gains except for lambs fed the dry crested wheatgrass hay but did improve feed efficiency except for lambs fed the moist alfalfa or the dry meadow fescue. Moistening the forage-grain rations improved rate of gain in all cases but the effect on feed efficiency varied with the forage.

5. Moistening dusty, ground hay-based rations was beneficial (the ground crested wheatgrass ration was the least dusty of the three rations). Moist rations would have to be prepared and fed fresh, daily in order to reduce spoilage and/or freezing.

\section{EFFECTS OF HAY:GRAIN RATIO, MOLASSES AND LINSEED MEAL ON PERFORMANCE OF FINISHING LAMBS}

Thirty-six crossbred lambs $(29.5 \mathrm{~kg})$ were divided into six groups comprising three ewes and three wethers. Medium-quality mixed brome and meadow fescue hay, ground through a $5 \mathrm{~mm}$ screen, was fed at levels of 20,50 and $80 \%$ of the ration. The $80 \%$ ration was also fed with $5 \%$ molasses, $10 \%$ linseed meal, or $5 \%$ molasses plus $7 \%$ linseed meal. Supplements replaced an equal weight of hay in the ration formula. The remainder of the ration was barley, cobalt-iodized salt (0.5\%), a mineral supplement (if required), vitamin $A$, and an antibiotic supplement.

Long hay was fed for 2 days prior to the test. Lambs started on the 20\% hay ration required 3 weeks before gains occurred and appeared to tire of their ration after 12 weeks of feeding (gains for those remaining averaged only $0.05 \mathrm{~kg} /$ day during latter part of test). An initial weight loss occurred in all lots and was probably due to an adjustment in rumen fill following removal of lambs from pasture. However, lambs fed the $80 \%$ level of roughage, alone or with any of the supplements, made good gains after the first week and, for the test as a whole, gained faster than those fed the high grain ration. The results of the test appear in Table 59.

At the prices of feed prevailing at the time of the experiment, returns were increased when either molasses or linseed meal was added to the $80 \%$-roughage ration. Adding both supplements decreased returns. 
Table 59. Lamb performance on rations containing mixed brome and meadow fescue hay

\begin{tabular}{|c|c|c|c|c|c|c|}
\hline & $\begin{array}{l}\frac{1}{20 \%} \\
\text { hay }\end{array}$ & $\begin{array}{l}\frac{2}{50 \%} \\
\text { hay }\end{array}$ & $\begin{array}{l}\frac{3}{80 \%} \\
\text { hay }\end{array}$ & $\frac{4}{75 \% \text { hay }}$ & 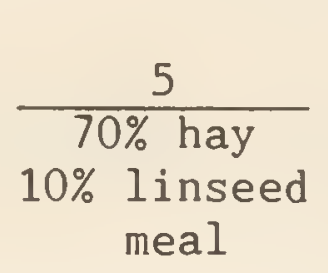 & $\begin{array}{c}6 \\
68 \% \text { hay } \\
5 \% \text { molasses } \\
7 \% \text { linseed } \\
\text { meal }\end{array}$ \\
\hline Crude protein (\%) & 14.2 & 12.3 & 11.2 & 11.2 & 11.3 & 13.8 \\
\hline Av. daily gain (g) & 141 & 195 & 191 & 222 & 250 & 250 \\
\hline Av. daily feed (kg) & 1.04 & 1.33 & 1.55 & 1.57 & 1.67 & 1.68 \\
\hline Feed/kg gain (kg) & 7.5 & 6.9 & 8.1 & 7.1 & 6.8 & 6.8 \\
\hline Final weight (kg) & 41.4 & 42.7 & 42.3 & 43.6 & 43.6 & 42.3 \\
\hline Dressing \% & 47.3 & 46.6 & 45.9 & 46.5 & 46.9 & 46.7 \\
\hline \multicolumn{7}{|l|}{ Carcass grade } \\
\hline - Choice & 4 & 3 & 2 & 5 & 3 & 1 \\
\hline - Good & 1 & 3 & 4 & 1 & 3 & 4 \\
\hline - Commercial & 1 & 0 & 0 & 0 & 0 & 1 \\
\hline
\end{tabular}

\section{VOLUNTARY INTAKE AND APPARENT DIGESTIBILITY OF DIETS CONTAINING VARYING LEVELS OF KOCHIA HAY, ALFALFA HAY AND BARLEY FED TO SHEEP}

Kochia is a drought-resistant, rapidly growing annual plant, widely adapted to many geographical areas, and especially to saline soils. Some consider kochia to be a noxious weed, but it is used for pasture and hay, mainly in the southern prairies during dry periods. Kochia is relatively high in crude protein and its nutritive value for ruminants could be as high as that of alfalfa, however, high mineral levels can be a problem limiting in take.

A Saskatchewan strain and a Texas strain of kochia were grown at Melfort, on moderately saline soil and harvested as hay at 18-20 percent moisture in early and late August. The Texas strain does not flower or set seed here, but the Saskatchewan strain flowers readily and produces abundant seed. Kochia dry matter yields averaged 2.6 and 7.2 tonne/ha for early and late cut, respectively, with little difference in yield between the strains.

As the level of kochia in the diet increased, dry matter intake by animals decreased (Table 60). There were no differences in dry matter or fibre digestibilities among the 4 forage diets. Crude protein and energy digestibilities were decreased with increasing levels of dietary kochia, while crude protein digestibility of the kochia/barley diet was lower than that of the alfalfa/barley diet. The results suggest that kochia can be incorporated into high-forage or grain-based rations at levels up to $50 \%$ without adverse effect on intake or digestibility. 
Some difficulties were encountered in establishing adequate intake and maintaining consumption with diets containing $75 \%$ kochia. Feed refusals with kochia diets were primarily coarse stemmy material.

Table 60. Composition, intake and digestibility of diets containing kochia (rounded to nearest whole number)

\begin{tabular}{|c|c|c|c|c|c|c|}
\hline \multirow{3}{*}{ Chemical Analyses (\%) } & \multirow{3}{*}{$\begin{array}{c}\text { Alfalfa/ } \\
\text { Barley } \\
(50: 50)\end{array}$} & \multirow{3}{*}{$\begin{array}{l}\text { Kochial } \\
\text { Barley } \\
(50: 50)\end{array}$} & \multicolumn{4}{|c|}{ Alfalfa/Kochia } \\
\hline & & & $25: 75$ & $50: 50$ & $75: 25$ & $100: 0$ \\
\hline & & & & & & \\
\hline Dry matter & 86 & 88 & 88 & 86 & 85 & 84 \\
\hline Crude protein & 15 & 13 & 14 & 16 & 16 & 17 \\
\hline Acid detergent fibre & 21 & 26 & 37 & 36 & 36 & 33 \\
\hline Ash (mineral) & 7 & 10 & 12 & 11 & 10 & 8 \\
\hline \multicolumn{7}{|l|}{ Digestibility (\%) } \\
\hline Dry matter & 72 & 70 & 62 & 63 & 64 & 66 \\
\hline Nitrogen & 74 & 69 & 69 & 74 & 74 & 76 \\
\hline Acid detergent fibre & 41 & 49 & 51 & 49 & 54 & 53 \\
\hline Energy & 70 & 68 & 59 & 61 & 62 & 64 \\
\hline \multicolumn{7}{|l|}{ Intake } \\
\hline$\overline{\text { Grams/day }}$ & 1001 & 899 & 652 & 858 & 931 & 1018 \\
\hline$\%$ body weight & 2.4 & 1.9 & 1.5 & 2.0 & 1.8 & 2.3 \\
\hline
\end{tabular}

\section{EFFECT OF FEED ADDITIVES, HIGH ENERGY SUPPLEMENTS AND PELLETING ON THE PERFORMANCE OF FINISHING LAMBS FED FORAGE-BASED RATIONS}

A feeding trial was carried out with $64,23 \mathrm{~kg}$, wether lambs, to evaluate the rations used in the steer finishing test described earlier in this publication. Apart from providing information of direct value to lamb producers, it was deemed of interest to determine whether lambs could be used in place of steers in evaluating steer finishing rations.

The rations were formulated, processed and fed under conditions described in the steer feeding trial, except that lambs were individually-fed indoors. The results are summarized in Table 61. Feed and processing prices are as shown for the steer trial. 


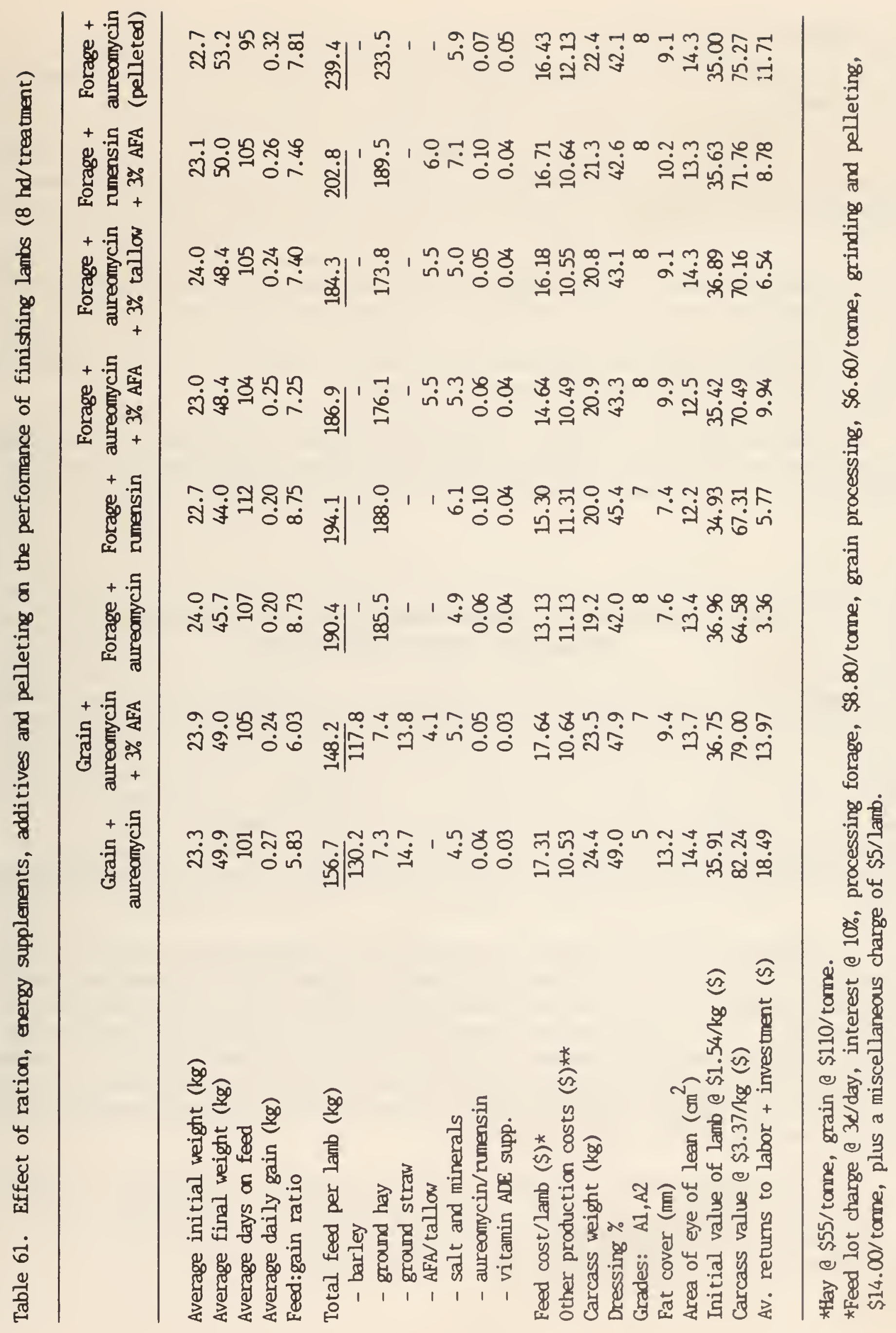


1. Lambs did not perform better when the grain ration was supplemented with $3 \%$ AFA.

2. Replacing aureomycin with rumensin in the forage ration improved dressing percentage and increased returns by $\$ 2.40$ per head. (It wasn't known if these lambs had coccidiosis, but if they had, the rumensin would be helpful.)

3. Adding AFA to the forage rations increased returns by $\$ 6.58$ per lamb when aureomycin was fed and by $\$ 3.01$ when rumensin was fed.

4. Tallow compared favorably with AFA but because of its higher cost, returned about $\$ 3.40$ less per head to labor.

5. Pelleting the forage + aureomycin ration increased rate of gain and returned an extra $\$ 8.35$ per head. However, these lambs reached heavier weights before becoming finished, which undoubtedly influenced returns.

\section{GENERAL GUIDELINES AND RECOMMENDATIONS FOR FINISHING LAMBS ON GROUND, HAY-BASED RATIONS}

Based on the results of the research it is evident that good performance and acceptable carcass grades can be obtained by feeding ground hay to finishing lambs. Performance can be affected by the quality, kind and level of hay in the ration and by moistening, pelleting and supplementing with energy and protein. When comparing the performance of finishing lambs and beef cattle, it appears that lambs respond better than do steers to increasing levels of ground hay in their rations. The following are suggestions to consider when using ground, hay-based rations for finishing lambs.

1. Aim for good to excellent quality hay (grass hays around $12 \% \mathrm{CP}$; legumes, $13-14 \% \mathrm{CP}$ ). If low quality hay is to be used, supplement the ration with canola meal or high protein wheat at a level to meet nutritional requirements. With high protein hay, diluting with ground cereal straw or adding a high energy supplement (tallow, canola oil or AFA) will provide a better balance. (While bloat was not experienced in these tests, it would be wise to dilute ground, good quality alfalfa hay with ground straw when the ration contains between $40-60 \%$ grain.)

2. Moistening dusty rations, where practical, can markedly improve performance. However, it may be more advantageous to use $2 \%$ of acidulated fatty acids (AFA) where available at reasonable cost $(22-23 \mathrm{c} / \mathrm{kg})$, particularly if a high-protein hay is being fed. 
3. Adding around $20 \%$ of a high protein grain (wheat) to a low protein, ground hay ration, may improve performance. Unless grain is very expensive, it is suggested that grain be fed in gradually increasing levels to about $40 \%$ during the last two weeks. This should maintain rate of gain and increase dressing percentage and possibly grades, depending on the quality of the hay fed.

4. While markedly differing effects were obtained with different types or qualities of hays, pelleting usually increased feed consumption, rate of gain, feed:gain ratio and dressing percentage and/or carcass grades, provided, in the case of lower quality hays, that they were supplemented with either energy or protein. Pelleting tended to narrow or eliminate differences in performance between lambs fed rations of different hay:grain ratios. Justification of pelleting will depend on convenience and cost.

5. Adding energy in the form of tallow or canola oil, improved performance only when added to the high-protein, hay-based rations. Because of the availability of acidulated fatty acids (AFA from canola) in some areas, its lower cost, and better mixing ability (compared to tallow) it may be a better supplement to use.

As with any livestock feeding enterprise, performance of lambs should be monitored on at least a weekly basis (by weighing a few representative lambs) and rations adjusted if required. The use of an antibiotic feed supplement (withdrawn from ration two weeks prior to slaughter), will likely improve performance, particularly in the less-than-sanitary conditions prevailing in most feedlots. Attention to vitamin A, mineral (especially phosphorus) and water requirements is imperative for optimum performance.

\section{BFFECT OF RATION ON EATING QUALITY OF THE MEAT}

\section{THE EFFECT OF RATION, BREED CROSS AND IMPLANTING ON THE PERFORMANCE OF FINISHING BEEF CATTLE AND ON THE EATING QUALITY OF THE MEAT}

A number of management factors were investigated in a feeding trial involving four lots of eight Simmental x Hereford steers (av. $369 \mathrm{~kg}$ on test) and four lots of eight Angus $x$ Hereford steers (av. $348 \mathrm{~kg}$ on test). Half of the steers within each lot were implanted with Synovex S. The four rations were: 1) high grain, 2) $20 \%$ grain, 3) high forage, and 4) one in which cattle were fed a high-forage ration initially, then gradually changed to a $58 \%$ grain ration. The rations are shown in Table 62. 
Table 62. Composition of rations fed (\%)

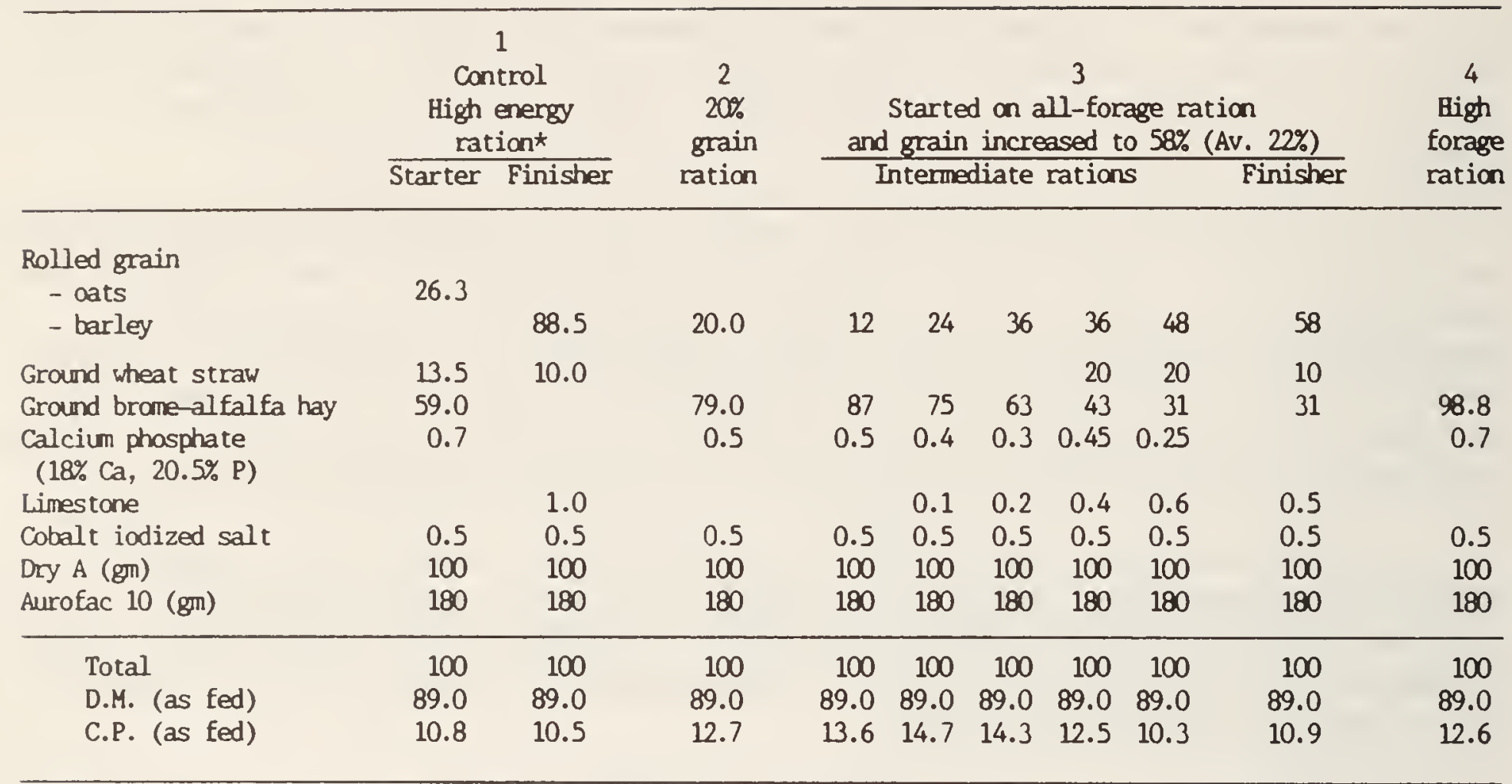

* Starter - days 1 \& 2; Starter:Finisher - 1:3, days $3 \& 4$; Starter:Finisher, 1:1 - days $5 \& 6$; Starter:Finisher, $1: 3$ - days 7 \& 8 ; Finisher - day 9 on.

Cattle were self-fed and had access to salt, a mineral mix and water, free-choice. They were marketed as they individually reached finished condition. All carcasses were assessed under the Blue Tag Program of the Production and Marketing Branch of Agriculture Canada. Rib roasts were obtained from the steers at the time of slaughtering, frozen, and shipped at the end of the test to the Food Research Institute in 0ttawa, for evaluation of eating quality. The effects of "breed" and ration are summarized in Table 63. The effect of the implant on rate of carcass gain of the two crossbreds by ration is summarized in Table 64, and the results of the effect of ration on eating quality are summarized in Table 65, along with some data on the effect of identical rations on the eating quality of lamb. 


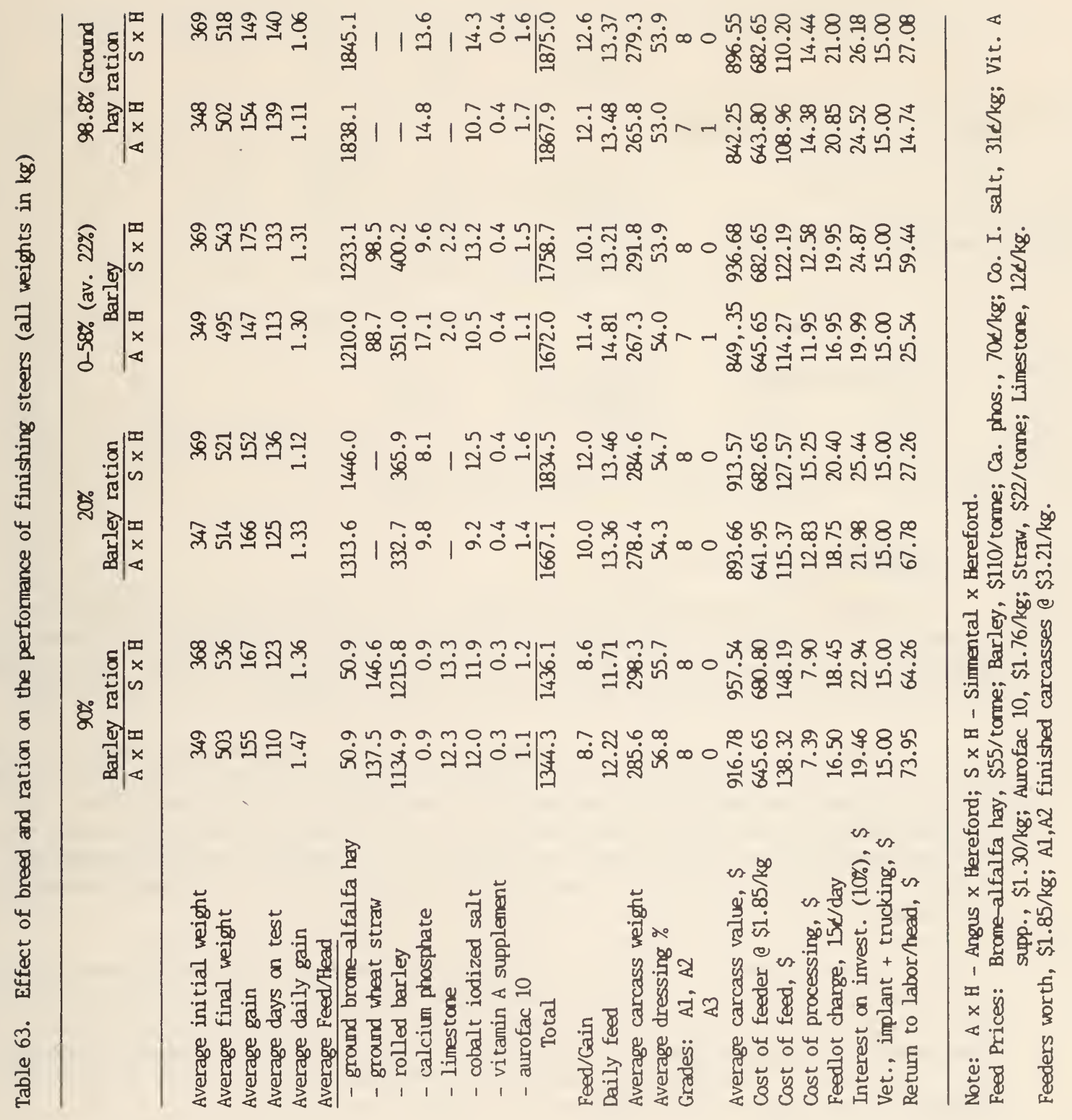


Table 64. Effect of implant (Synovex S) on rate of carcass gain of two types of crossbred steers fed four different ration

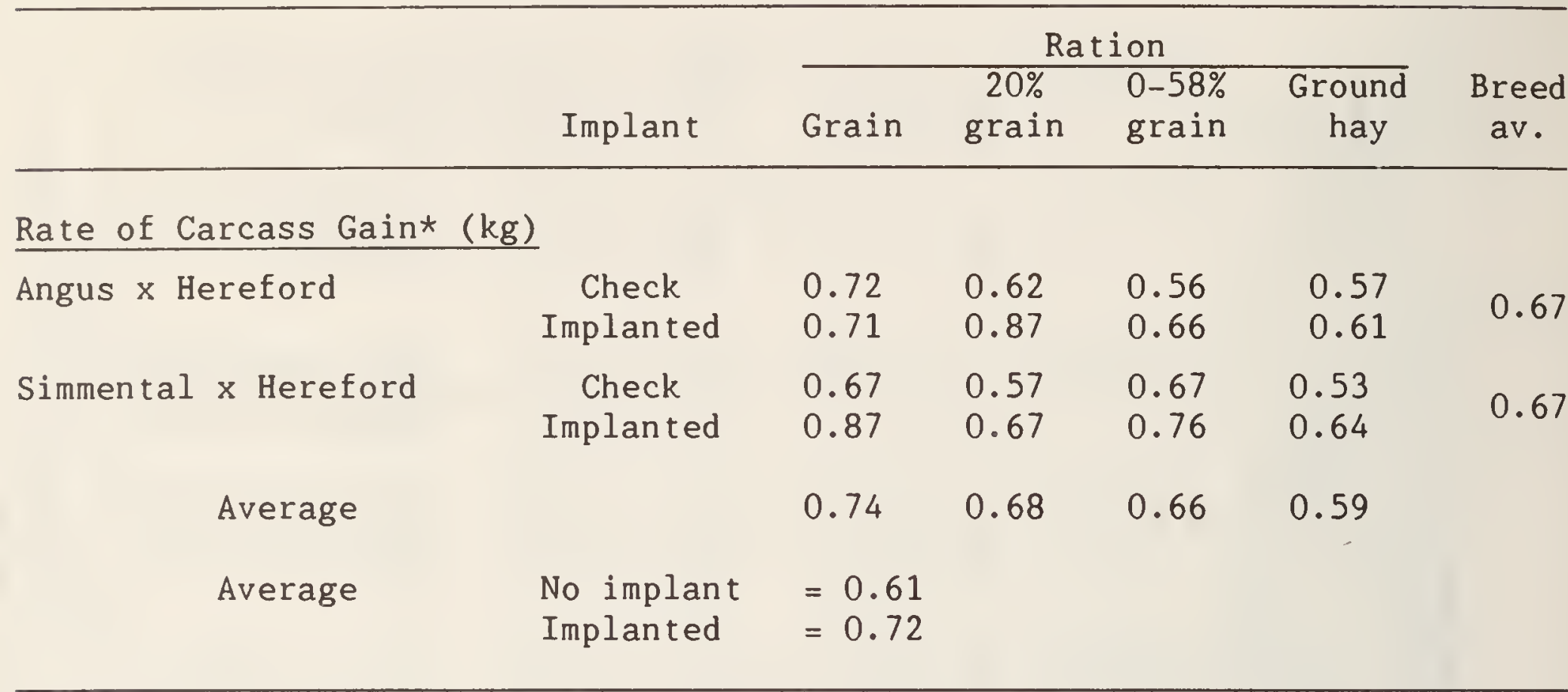

* Rate of liveweight gain $\mathrm{x}$ dressing percentage.

\section{Comments (Table 64)}

1. Rate of carcass gain was highest for steers fed the high-grain ration $(0.74 \mathrm{~kg} / \mathrm{hd} / \mathrm{day})$ and lowest for those fed the ground hay ration $(0.59$ $\mathrm{kg} / \mathrm{hd} /$ day). Steers fed $20 \%$ grain or those receiving an average of $22 \%$ grain with most of it fed during the last few weeks, averaged $0.67 \mathrm{~kg} / \mathrm{head} / \mathrm{day}$.

2. To attain comparable liveweight at marketing required, on average, about three weeks longer for the forage-fed steers and about 10 days longer for those fed the low levels of barley. Because of the large effect of carcass weights (and value) on returns, it is evident that the steers fed the high forage rations should have been fed to the maximum weight possible without causing overfinish, assuming that rate of gain and feed conversion efficiency were maintained at satisfactory levels.

3. There appeared to be an interaction between breed cross and feeding method with the Angus $x$ Herefords performing better on the $20 \%$ barley ration than on the ration which had the increasing level of barley, while the Simmental $x$ Herefords performed better on the ration with the increasing level of grain. The major reason for the difference, in returns per head, appears to be due to the difference in market weights.

4. The effect of the growth promoting implant on rate of gain was quite marked, except for the Angus $x$ Hereford crossbreds fed the high grain ration.

5. Valuing the barley at $11 \mathrm{c} / \mathrm{kg}$ and the hay at $5.5 \mathrm{c} / \mathrm{kg}$, the economics 
favored the cattle fed the high barley ration, with quite acceptable returns on the Angus $x$ Hereford cattle fed the $20 \%$ grain ration, and the Simmental $x$ Herefords fed increasing amounts of grain over the finishing period.

Including at least some grain in forage-based rations would appear to be a sound practice under the normal prices for hay and grain experienced.

Table 65. The effect of ration on the eating quality of beef and lamb (Score $0-15$, with 15 best rating)

\begin{tabular}{lrrrr}
\hline & $\begin{array}{c}\text { High } \\
\text { grain }\end{array}$ & $\begin{array}{c}20 \% \\
\text { grain }\end{array}$ & $\begin{array}{r}0-58 \% \\
\text { grain }\end{array}$ & $\begin{array}{r}\text { Ground } \\
\text { forage }\end{array}$ \\
\hline Beef & & & & \\
Flavor & 8.04 & 8.55 & 8.35 & 8.50 \\
Juiciness & 7.11 & 8.19 & 8.28 & 8.14 \\
Tenderness & 8.10 & 8.21 & 8.98 & 7.92 \\
Sheer force to cut & 1126 & 1130 & 1049 & 1151 \\
Weight loss on cooking (\%) & 24.5 & 22.2 & 22.3 & 21.4 \\
Dripping (\%) & 6.3 & 6.2 & 5.9 & 5.6 \\
Lamb & & & & 7.3 \\
Flavor & 7.2 & 7.5 & 7.4 & 8.2 \\
Juiciness & 7.6 & 7.2 & 8.2 & 8.9 \\
Tenderness & 8.8 & 8.4 & 777 & 641 \\
Sheer force to cut & 696 & 776 & & \\
\hline
\end{tabular}

Comments (Table 65)

1. Meat from steers fed the all-forage or high-forage rations was on average, equal or superior in eating quality to that from grain-fed steers, although all-forage-fed steers produced slightly (a non-significantly) tougher meat.

2. Roasts from lambs fed the high forage rations were superior to those from lambs fed the high grain ration.

\section{EATING QUALITY OF FORAGE AND GRAIN FED BEEF FROM STEERS AND HEIFERS}

One of the myths about beef is that "grain-fed" beef is superior to "grass-fed" beef, perhaps because when steers were finished on range, over a two to three year period, they produced beef that was older, probably tougher and contained less fat, particularly marbling, than did beef from the younger, more rapidly finished cattle fed high grain rations in the feedlot. We have shown that beef cattle fed mainly ground hay-based rations, particularly if supplemented with from $3-4 \%$ of a high energy product such as 
tallow or acidulated fatty acids, can reach acceptable standards for Canada Grade A1 or A2 carcasses within a feeding period about three weeks longer than comparable grain-fed steers. It was thought important, to determine whether the beef from cattle fed ground hay-based rations was any different, in terms of eating quality, than that of grain-fed steers so that the consumer would be reliably informed.

Several previous studies in which meat from forage and grain-fed steers was evaluated by professional taste panels at the Food Research Institute in ottawa, showed that "forage-fed" beef was at least on a par with grain-fed beef with respect to tenderness, flavor and juiciness. As part of a feeding test carried out to compare the performance of steers and heifers fed various proportions of ground alfalfa and crested wheatgrass hays, with that of comparable cattle fed a rolled barley-based ration, roasts were obtained from cattle fed the crested wheatgrass (96\%), alfalfa $(97 \%)$ and barley $(85 \%)$ rations and sent to the Food Research Institute in ottawa for sensory evaluation. All rations contained about $2 \%$ AFA and were supplemented with minerals, vitamin $A$ and an antibiotic. The results of the meat evaluation tests are shown in Table 66.

Table 66. Eating quality and other criteria of beef roasts from steers and heifers fed various finishing rations

\begin{tabular}{cccc}
\multicolumn{2}{c}{ Steers } & \multicolumn{2}{c}{ Heifers } \\
\cline { 3 - 4 } CWG Alfalfa Barley & & \\
\end{tabular}

\section{Sensory Parameters}

$\begin{array}{lrrrrrrr}\text { Flavor } & 8.0 & 7.7 & 8.0 & 8.9 & 8.2 & 7.7 & 0.63 \\ \text { Tenderness } & 8.8 & 7.3 & 8.6 & 10.6 & 9.1 & 8.3 & 1.38 \\ \text { Juiciness } & 9.0 & 7.1 & 6.9 & 9.2 & 8.3 & 6.7 & 1.34\end{array}$

Mechanical/Physical Parameters

\begin{tabular}{lllllllc}
\hline Free moisture $(\%)$ & 40.8 & 38.9 & 38.1 & 41.1 & 40.3 & 40.6 & 4.52 \\
W-B Shear $(\mathrm{g} / \mathrm{cm})$ & 1552 & 2004 & 2163 & 1562 & 1873 & 1773 & 310.41
\end{tabular}

Cooking Parameters

$\begin{array}{lrrrrrrr}\text { Weight loss (\%) } & 23.9 & 21.1 & 26.2 & 21.4 & 16.7 & 22.5 & 4.37 \\ \text { Drip loss (\%) } & 4.1 & 3.8 & 6.2 & 2.8 & 4.0 & 4.9 & 1.01\end{array}$

${ }^{1}$ Maximum standard error of the difference between two diets for heifers or steers.

\section{Comments (Table 66)}

1. There was no significant difference in flavor, tenderness or juiciness between grain and forage-fed beef. 
2. Grain-fed heifer beef scored between $0.2-0.3$ points less than grain-fed steer beef, while forage-fed heifer beef scored consistently higher than forage-fed steer beef for flavor, tenderness and juiciness. It is interesting to note that both steer and heifer meat from crested wheatgrass-fed cattle scored much higher than meat from alfalfa-fed cattle and higher on average, than grain-fed cattle.

3. Heifer beef lost less weight during cooking than did steer beef but the somewhat lower weight loss of "forage" vs "grain" beef was not significant.

4. Drip loss (primarily fat) was significantly greater for "grain" beef than for "forage" beef, probably due to the fact that grain-fed cattle carried more fat ( 9.7 vs $7.2 \mathrm{~mm}$ backfat thickness).

5. We conclude that "forage" beef is leaner, and of at least equal eating quality to that of "grain" beef, other factors (except market weight) being equal.

\section{FEEDING PRACTICES AND FEEDER DESIGNS}

\section{HAND OR LIMIT FEEDING LIVESTOCK}

When limit feeding hay, silage or grain to livestock it is very important to manage the operation so that all animals receive their share of the feed. This is difficult to achieve when the group of animals being fed are of different ages/sizes or where some aggressive individuals can dominate the feeding area.

The following suggestions should eliminate or minimize the problem:

1. Where numbers warrant, livestock should be separated into uniform lots with respect to sex, size and condition. This will allow each group to be fed according to their needs and avoid, or limit, over- and under-feeding of any one type of animal.

2. Provide adequate space at the feed bunk so that all animals can feed at the same time [cows and heavy feeders, $66 \mathrm{~cm}$ (26"); yearlings up to $340 \mathrm{~kg}$ (700 lb.), $56 \mathrm{~cm}$ (22"); calves up to $227 \mathrm{~kg}$ (500 lb.), $46 \mathrm{~cm}$ (18"); ewes and rams, $40 \mathrm{~cm}$ (16"); feeder lambs, $30 \mathrm{~cm}\left(12^{\prime \prime)}\right)$. Be sure that enough space is provided at self feeders, waterers and mineral boxes to assure each animal adequate access within each 24 hour period.

3. If aggressive animals are present in a group, provide several feeding areas to permit the more timid animals to avoid them, or provide a number of solid partitions at the feed bunk to protect timid animals from lateral attack. 


\section{MINIMIZING UASTAGE OF FEED}

From the time of cutting, until consumed by the animal, there can be considerable physical spoilage and quality losses of forage, which will adversely affect the efficiency and economics of forage harvesting, storage and utilization. Small losses of any one stage may seem insignificant, but because wastage or quality loss can occur at so many stages in the forage system, the cumulative losses can vary from less than $5 \%$ to, in extreme cases (i.e. bales rotting in the field), 100\%. Average losses between harvesting systems varied from 9.5 to $22 \%$ in studies conducted at Melfort. (See "Forage Harvesting in the Aspen Parkland of Western Canada", Publication 1547, revised 1990.)

In this publication we will confine the discussion of losses to processing and feeding practices. The following points summarize the causes of forage losses.

\section{Handling and processing losses (estimate 0-22\%)}

1. Wastage around silos, particularly pile, bag or bunker types, during removal of silage, due to careless operation of equipment resulting in physical losses or contamination of silage with soil.

2. Failure to remove enough silage from the face of a bunk, trench or pile silo, daily, to minimize spoilage (at least $10 \mathrm{~cm}$ in winter and $15 \mathrm{~cm}$ in the summer).

3. Incomplete pick-up of hay stacks being moved to feeding areas.

4. Loss of hay due to failure to salvage broken bales, recover spilled forage, etc..

5. Loss of fine material during grinding, mixing, and conveying of ground hay to feeders, caused by wind, improper use of equipment or by leakage of feed from equipment (eg. fine material dropping out of a tub grinder to being blown from the conveyer). bunks).

6. Failure to recover spilled forage wherever practical (around feed

\section{Losses during feeding (estimate 2-4\%)}

1. Loss of finely ground hay or silage when filling self-feeders or bunks - due to wind, careless handling of equipment, overfilling feed bunks, etc..

2. Losses due to trampling, fouling, etc., when hay stacks, round bales, etc., are self-fed without the use of a feeding gate. 
3. Feeding hay or silage on the ground, unless fed in amounts that can be "clean up" quickly on frozen or hard surfaces.

4. Using improperly designed feeders, which permit cattle to pull or push feed out of the feeder; which allow feed to become wet and spoiled, or which are designed to permit dead spots where feed becomes stale or spoils. Hay feeders, in particular, should be designed so that the animal has to put its head through a gate of some type before contacting the feed, thus encouraging it to eat in the feeder rather than to pull out a mouthful of feed held against upright bars, which usually results in part of the mouthful falling to the ground. Use of the tombstone type gate (Fig. 10) or of sloped uprights (Fig. 11) in the feeding gate will require the animal to lift or twist its head before reaching the feed, thus reducing the tendency to pull feed from through the gate.

\section{SELF-FEEDER FOR GROUND HAY AND/OR GRAIN-BASED RATIONS FOR GROWING-FINISHING BEEF CATTLE}

Most of the self-feeders available on the market today are designed for feeding high-concentrate rations. The "eat-through" feeder shown in Fig. 9 was designed for self-feeding of feeds, varying from bale slices to all-grain rations. Regardless of the design, self-feeders require regular inspection and adjustment to be sure that feed is not being wasted.

\section{Construction}

1. Prepare two $15 \times 15 \mathrm{~cm}$ (6" $\left.\times 6^{\prime \prime}\right)$ treated skids (5.8 m (22') long (or use laminate treated "2 $26 "$ "'s).

2. Place $122 \mathrm{~cm}\left(4^{\prime}\right)$ apart (inside measurement) and tie together with three spacer pipes (approximately $5 \mathrm{~cm}$, or $2 "$ diameter), with welded inside "stops" and threaded ends (Fig. 9).

3. Construct two wall frames using " $2 \times 6$ " material, $5 \mathrm{~m}$ (16') high, $6.2 \mathrm{~m}\left(20^{\prime}\right)$ long, with studding $41 \mathrm{~cm}$ (16") o.c.. Attach plywood sheeting to the inside of the frames to within $61 \mathrm{~cm}$ (24") of the floor of the feeder. Frame a $76 \times 76 \mathrm{~cm}\left(30 \times 30^{\prime \prime}\right)$ opening at middle of one side for an access door.

4. Attach walls to skids with spikes or lag bolts. Tie together at top with six "2 $x 4$ " ties beveled at the ends to match roof slope (at the ends and at $1 / 5$ intervals) and at bottom with "2 $\times 4 "$ fir sills cut long enough to extend $25 \mathrm{~cm}$ (10") past the studs, one across each set of studs. Nail the sills in place lying on the wall plate (Fig. 9).

5. Fit 1" plywood floor over sills. 
6. Install divider. Cover plywood on divider with smooth metal sheeting.

7. Set and attach rafters with collar braces; nail on $1 " \times 3$ " nailing girts for metal sheeting.

8. Line inside of wall sections with plywood sheeting to within $61 \mathrm{~cm}$ (24") of floor.

9. Attach end " $2 \times 4$ " studs, allowing for a hatch at the top of each end for filling by blower or auger. This hatch should be fitted with a sliding door which can be opened (up or down) with a rope and pulley.

10. Line inside of end sections with plywood sheeting.

11. Fit side bottom openings with plywood doors at least $61 \mathrm{~cm}$ (24") high. To keep them from moving inwards, nail plywood strips, $10 \mathrm{~cm}$ (4") wide, to inside bottom of each stud, extending $2.5 \mathrm{~cm}$ (1") past the stud on each side. Strips of "1 x 2" material can be nailed along inner sides of studs to hold doors from pushing outwards (Fig. 9).

12. Place $2 \times 10^{\prime} \mathrm{s}$ along sides of feeder floor to form side of feeding trough. Nail $20 \mathrm{~cm}$ ( 8 ") pieces of " $2 \times 10 "$ material at every fourth or fifth stud to hold edge of trough in place. For best "fix", attach a piece of strap iron to stud and run it across tops of short " $2 \times 10 "$ blocks and down outside edge of the trough and screw to ends of "2 $\times 4$ " floor sills.

13. Frame and attach braced rafters $\left(2 \times 4^{\prime} s\right)$ to studding to support protective roof sections. Attach nailing girts for metal roofing.

14. Attach metal roofing-siding to roof, to protective roof sections and walls above them, and to end sections. Treated wooden sheeting can be used instead, to reduce construction costs, but the metal reduces upkeep costs and improves appearance. Attach frame at upper ends to hold sliding doors to cover filling hatches.

15. Frame end sections (optional) to fit under overhanging protective roof. Make frame of " $2 \times 6 "$ material (on the flat), line inside with plywood sheeting and outside with metal siding, preferably backed by plywood. Attach these end sections by heavy hinges to the feeder, and anchor on outside end, to protective roof and concrete pad by means of a heavy barrel bolt. To provide added protection against being pushed out by feeding cattle, a heavy angle iron bar can be placed right across end of structure about 4 feet off the ground and held in place with angle-iron brackets (this allows bar to be lifted out easily when structure is to be moved). 


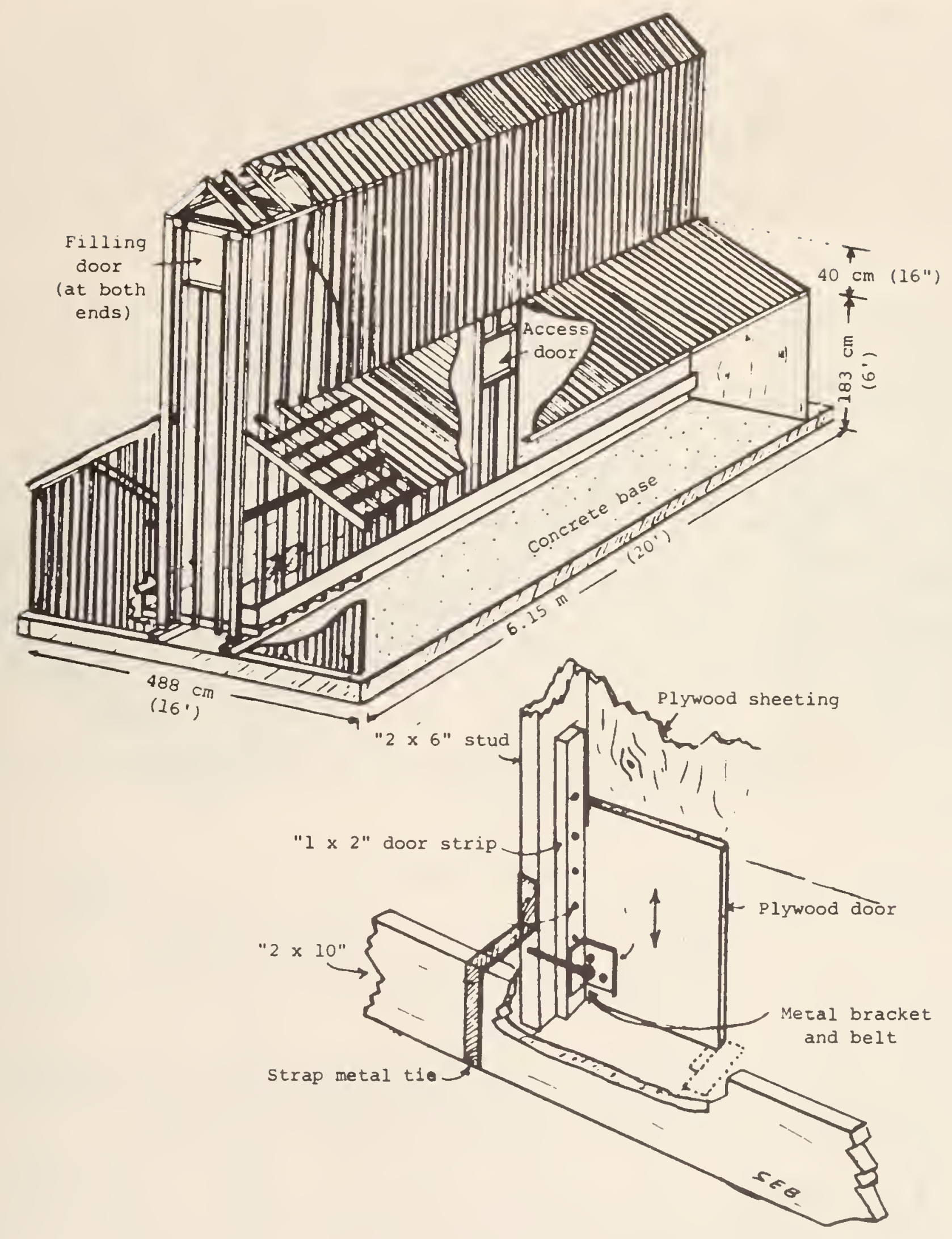

Fig. 9. "Eat-through" self-feeder for ground hay and/or grain rations for growing-finishing beef cattle.

\section{TOMBSTONE FEEDER}

The tombstone feeder is designed to reduce wastage when self-feeding long (baled) or loose forages to beef cattle. It forces the animals to raise 
their heads when "entering" or "leaving" the feeder, thus reducing the likelihood of animals pulling feed out of the feeder and dropping it on the ground. The design shown in Fig. 10, takes into account the fact that mature beef cows need from 61 to $66 \mathrm{~cm}$ (24-26") of feeding space when eating side to side. Narrower spacings may suffice where animals can "radiate" from the feeder (round feeder, or short-sided square feeder - maximum $3.7 \mathrm{~m}$ side). Uprights can be nailed to the wall of the feeder and clinched on the inside, or they may be bolted (using large washers). Bolting may take longer, but makes it easier to replace broken uprights.

It is suggested that rough " $2 \times 8$ " spruce lumber be used because of its strength and cost. The inside of the feeding openings should be smoothed out to prevent injury from splinters. Ends of wall sections are at tached using heavy duty hinges or preferably, as shown in the figure, by means of short pipe sections welded to "U-shaped" metal brackets, bolted to the ends of the horizontal planks (top half of top plank and bottom half of middle plank at one end, and the bottom half of the top plank and top half of the bottom plank, at the other end). The ends can be lined up and a snug-fitting pipe or rod placed through the pipe end of the brackets to hold the corners firmly in place. If it is intended that cattle be able to push the unit together to reach feed in the middle, the pipe sections of the hinges must be set further out to allow folding to less than 90 degrees. This type of corner fastener facilitates moving of the feeder or access for refilling (if required) or cleaning .

It is recommended that the whole unit be placed on a concrete slab, especially if soil is poorly drained.

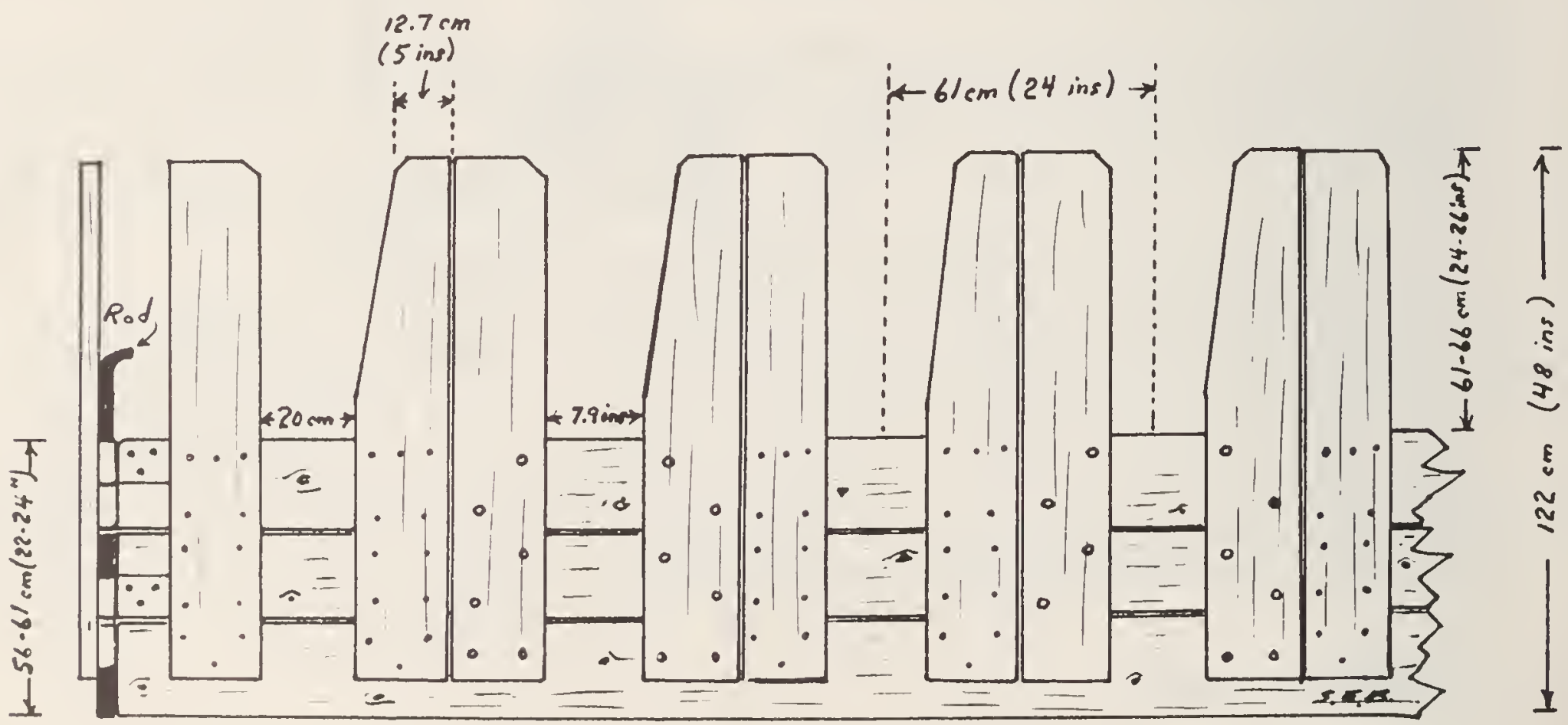

Fig. 10. Elevation - tombstone feeder for large framed beef cows. 


\section{STANDARD, ROUND BALE AND STACK FEEDER}

Standard, round bale and stack feeders (Fig. 11) should be designed and managed to keep the hay far enough away from the feeding gate to permit cattle to eat with their heads within the feeder and provide some means (movable electric "fence", hinged gates, manual or mechanical moving of inaccessible feed) of keeping adequate feed within the animal's reach.
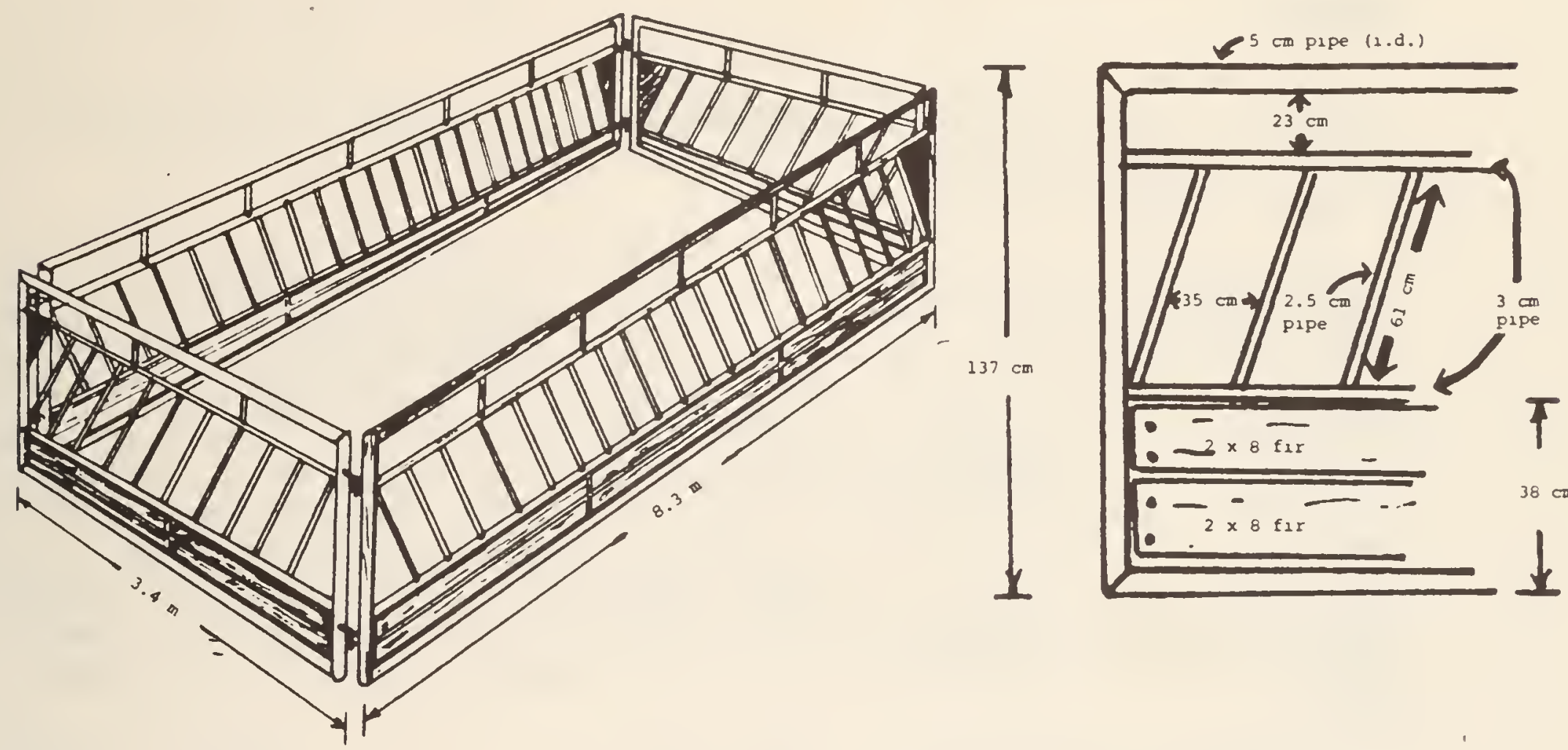

Note: Triangular sections (V) should be blocked to prevent trapping heads should animals go down.

Fig. 11. Stack feeding corrall

\section{"EFFICIENCY" OF BEEF PRODUCTION: FORAGE AND GRAIN REQUIRED TO PRODUCE A UNIT OF DRESSED BEEF UNDER THREE FEEDING SYSTEMS}

The beef industry is often criticized by vegetarians and environmentalists, for the inefficient conversion of cereal grains to edible beef, with the suggestion that it would be better to feed grain directly to humans. For many reasons this argument is impractical, ignoring the ability of many needy consumers to pay, and problems of distribution and preservation during handling and storing. Because of our considerable work on producing beef on all kinds of rations and our involvement with the whole beef cattle enterprise from the cow to the finished animal, we felt it would be interesting to determine just how much forage, straw and grain it would take to produce a unit of meat (dressed carcass plus edible organs and other 
tissues not included in the carcass). The results are summarized in Table 67. It must of course be recognized that in practice, there is a wide variety in both the kind and quality of feeds fed to beef cattle and that cattle vary in their productive potential. Environments vary, and feeding management varies. Nevertheless, we feel that the data are reasonable and relative across the three systems considered.

\section{COMKENTS}

The amount of cereal grain required to produce a unit of beef varies from none to about $81 / 2$ units depending on the production system used, from all forage-based rations to the maximum use of grain in the growing-finishing stages.

When grain is low cost and/or lacks a market, it is logical and economically essential that it be marketed through livestock. With barley currently worth $6.8 \mathrm{c} / \mathrm{kg}$ (Wheat Board price), plus perhaps a $2.3 \mathrm{c} / \mathrm{kg}$ final payment, it is obvious that production costs are not being met. If an $A_{1}$ carcass is worth $\$ 3.20 / \mathrm{kg}$, and other feed and production costs (including $40 \mathrm{c} / \mathrm{kg}$ return to labor) are subtracted, there is left $\$ 2.01$ to cover the cost of the $12.1 \mathrm{~kg}$ of barley or $16.6 \mathrm{c} / \mathrm{kg}$, a 1.82 fold increase over market value. (Note this does not take into account any change in the unit value of the live animal from feeder to finished condition.) Not only is the value of the grain increased by feeding to livestock, but the food produced is far superior in nutritional quality per unit consumed, then is the original grain.

\section{Comments (Table 67)}

Intake data are based on feeding trials at the Melfort Research Station and on recommended feeding standards. Intake of forage by calves prior to and while on pasture are estimated.

It is assumed for simplicity, that the starting point is a two year old heifer just prior to calving and that the weight of her dressed carcass at the end of her productive life ( 8 years of age) is credited to the production of meat over six years. 
Table 67. Estimated hay and grain required to produce a unit of dressed beef under three different feeding systems* (All weights $\mathrm{kg} / \mathrm{lb}$ - feeds on $90 \%$ DM basis)

Feeding System

Forage-based Grain-Based Forage \& grain based

Feeding the cow $(590 / 1300)$

Pasture (150 days)

$2409 / 5300 \quad 2409 / 5300$

$2409 / 5300$

Drylot (215 days)

- hay/silage

$1364 / 3000 \quad 182 / 400$

- straw

$1273 / 2800$

$1364 / 3000$

$727 / 1600$

- grain

$0 / 0$

$880 / 1935$

$1320 / 2900$

$500 / 1100$

Calf (birth to weaning) (41-225/90-500)

Hay and pasture (185 days) 500/1100

$500 / 1100$

$500 / 1100$

Growing calf (227-385/500-850)

Drylot (160 days)

- hay/silage

$1705 / 3750$

$0 / 0$

- straw

- $\quad 318 / 700$

-grain

$-$

$1127 / 2480$

$970 / 2130$

$0 / 0$

$570 / 1250$

Finishing steers (385-570/850-1250)

Hay

Straw

Grain

$\begin{aligned} & \text { Total } \text { - Forage } \\ & \text { - Straw } \\ & \text { - Grain }\end{aligned}$

Estimated meat yield

Steer carcass
Cow carcass $(1 / 6)$

other edible tissue (organs,

head meats, backskirt)

Total
$1820 / 4000$

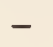

$-$

$7795 / 17150$

$1273 / 2800$

$0 / 0$

$301 / 663$

$49 / 108$

$\frac{15 / 33}{365 / 804}$
$0 / 0$

$130 / 290$

$1205 / 2650$

$3091 / 6800$

$1814 / 3990$

$3211 / 7065$
$773 / 1700$

$68 / 150$

$682 / 1500$

$5377 / 11830$

$1386 / 3050$

$1750 / 3850$

$313 / 688$

$49 / 108$

$49 / 108$

$\frac{16 / 34}{377 / 830}$

Units of feed/unit beef produced

\begin{tabular}{lrrr}
\hline Hay/silage & 21.3 & 8.1 & 14.3 \\
Straw & 3.5 & 4.7 & 3.7 \\
Grain & 0.0 & 8.4 & 4.6 \\
$\quad$ Total & $\underline{24.8}$ & $\underline{21.2}$ & $\mathbf{2 2 . 6}$
\end{tabular}

* Main ration ingredients (hay, straw, grain) must be supplemented with the appropriate minerals and vitamin A. It is assumed that pasture, hay, straw and grain are of average to good quality, and that growing-finishing rations are ground (or grain rolled) and that ground hay rations contain 3\% A.F.A. (high energy, dust-controlling by-product of the manufacturer of canola oil). 

Recycled
Paper 
Canadää 